\title{
DOSES DE NITROGÊNIO E DE POTÁSSIO PARA PRODUÇÃO, COMPOSIÇÃO E DIGESTIBILIDADE DOS CAPINS COASTCROSS 1 E TIFTON 85 EM UM LATOSSOLO VERMELHO-AMARELO
}

\author{
RENATA APARECIDA MARTIM \\ Engenheira Agrônoma
}

Orientador: Prof. Dr. FRANCISCO A. MONTEIRO

Dissertação apresentada à Escola Superior de Agricultura "Luiz de Queiroz", da Universidade de São Paulo, para obtenção do título de Mestre em Agronomia, Área de concentração: Ciência Animal e Pastagens.

P I R A C I C A B A

Estado de São Paulo - Brasil

Fevereiro - 1997 
Dados Internacionais de Catalogação na Publicação (CIP) DIVISĀO DE BIBLIOTECA E DOCUMENTAÇÃO - Campus "Luiz de Queiroz"/USP

Martim, Renata Aparecida

Doses de nitrogênio e de potássio para produção, composição e digestibilidade dos capins Coastcross 1 e Tifton 85 em um Latossolo Vermelho-Amarelo / Renata Aparecida Martim. - - Piracicaba, 1997. 109 p. : il.

Dissertação (mestrado) - - Escola Superior de Agricultura Luiz de Queiroz, 1997. Bibliografia.

1. Capim coastcross 12 . Capim tifton 85 3. Digestibilidade 4. Graminea forrageira 5. Nitrogênio 6. Nutrição mineral 7. Potássio 1. Título 


\section{DOSES DE NITROGÊNIO E DE POTÁSSIO PARA PRODUÇÃO, COMPOSIÇÃO E DIGESTIBILIDADE DOS CAPINS COASTCROSS 1 E TIFTON 85 EM UM LATOSSOLO VERMELHO-AMARELO}

RENATA APARECIDA MARTIM

Aprovada em: 25.03 .1997

Comissão julgadora:

Prof. Dr. Francisco Antonio Monteiro

ESALQ/USP

Prof. Dr. Cláudio Maluf Haddad

ESALQ/USP

Prof. Dr. Disnei Antonio Gonçalez

FMVZ/UNESP

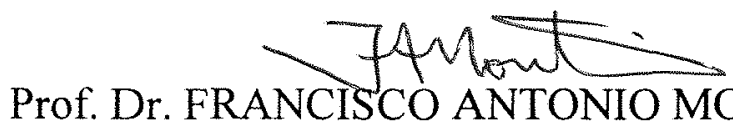

Orientador 
Aos meus pais pela educação que me proporcionaram,

\section{OFEREÇO.}

Ao PAULO ROBERTO pelo amor, apoio e incentivo,

DEDICO. 


\section{AGRADECIMENTOS}

Ao Prof. Dr. Francisco Antonio Monteiro pela orientação inestimável, pela atenção e pela paciência prestadas na realização desse trabalho.

Ao Prof. Dr. Antonio Roque Dechen e ao Prof. Dr. Quirino Augusto de Camargo Carmello pela amizade e apoio dedicados.

Ao Prof. Dr. Henrique Paulo Haag (in memorian) pelo incentivo ao estudo com nutrição de plantas.

A todos os professores do curso de Ciência Animal e Pastagens da ESALQ/USP.

Ao médico veterinário Luiz Alberto Marinho pelo apoio, incentivo e pela credibilidade na pesquisa.

Ao engenheiro agrônomo Ricardo Mickenhagen pelo fornecimento das mudas de Tifton 85 .

Ao meu amigo o engenheiro agrônomo Waldssimiler Teixeira de Mattos pelo coleta das mudas de Coastcross 1 , gentilmente cedidas pelo Instituto de Zootecnia, de Nova Odessa-SP, através do Prof. Dr. Herbert Barbosa de Mattos.

Aos estagiários Carlos Augusto Martins Vieira, Flávia Sarkis, Gláucia Regina Anti e Plínio Marcos Frare pela ajuda na montagem e no corte das plantas do experimento.

A Patrícia Pessini pelo fornecimento do solo para esse experimento.

Ao Carlos Cézar Alves pela amizade e pelo apoio nas análises bromatológicas.

A Ednéia Cristina Sceroino Mandoni, Fernando Éder Ré, Lúcia Helena S. Forti, Lurdes Aparecida Dário de Gonzales, Mirtes Ventura Sesso, Nivanda Maria de Moura e Sueli Maria Amaral Campos Bovi pela amizade e auxílio. 
Aos colegas do curso de Ciência Animal e Pastagens, e em especial a engenheira agrônoma Beatriz Dias Corrêa pela amizade e apoio dedicados.

A todos os colegas da Área de Nutrição Mineral de Plantas pelo companheirismo.

À CAPES pela concessão de bolsa de estudos.

Ao Jockey Club de São Paulo pelo apoio financeiro prestado para a realização deste trabalho. 


\section{SUMÁRIO}

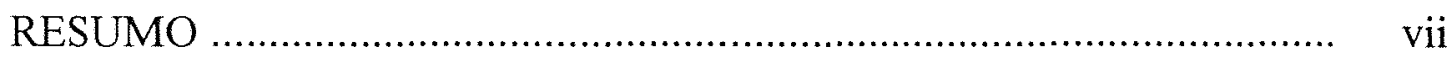

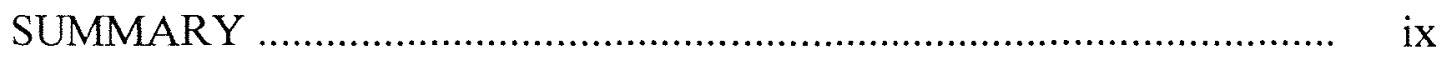

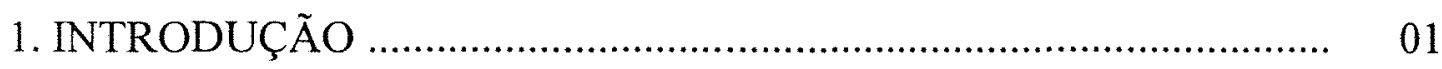

2. REVISÃO DE LITERATURA …..................................................... 03

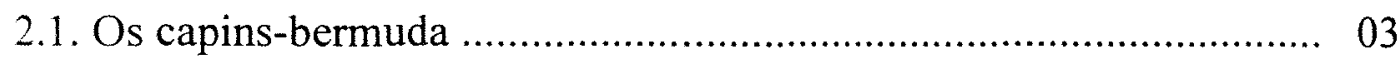

2.2. Adubação nitrogenada e potássica e a produção de matéria seca .... 06

2.3. Relação haste:lâmina nas forrageiras ............................................... 09

2.4 Composição química e digestibilidade das forrageiras .................... 11

2.4.1. Concentração de nitrogênio nos tecidos ................................. 11

2.4.2. Concentração de potássio nos tecidos e no solo ....................... 16

2.4.3. Concentração de fósforo nos tecidos ...................................... 19

2.4.4. Concentração de cálcio nos tecidos ........................................ 20

2.4.5. Concentração de magnésio nos tecidos .................................. 21

2.4.6. Fibra em detergente ácido (FDA) e detergente neutro (FDN) .. 22

2.4.7. Digestibilidade …............................................................... 25

3. MATERIAL E MÉTODOS ......................................................... 31

3.1. Gramíneas estudadas .............................................................. 31

3.2. Local e periodo .................................................................. 31

3.3. Preparo do substrato .......................................................... 32

3.4. Preparo das mudas e plantio ………………................................. 33

3.5. Delineamento experimental e análise estatística .......................... 33 
3.6. Adubação básica e doses de nitrogênio e de potássio ...................... 34

3.7. Coleta e pesagem do material ..................................................... 36

3.8. Determinação do teor de nutrientes, fibras e digestibilidade in vitro da matéria seca ...................................................................... 36

4. RESULTADOS E DISCUSSÃO …............................................... 38

4.1. Produção de matéria seca da parte aérea e das raízes ...................... 38

4.2. Relação haste:lâmina nos capins ..................................................... 44

4.3. Concentração de nitrogênio nos tecidos vegetais ........................... 50

4.4. Concentração de potássio nos tecidos vegetais .............................. 57

4.5. Concentração de fósforo nos tecidos vegetais .................................. 64

4.6. Concentração de cálcio nos tecidos vegetais .................................. 67

4.7. Concentração de magnésio nos tecidos vegetais ............................. 71

4.8. Concentração de FDN e FDA ….................................................... 75

4.9. Digestibilidade in vitro da matéria seca ....................................... $\quad 80$

4.10. Concentração de nutrientes e saturação por bases no solo ............ 85

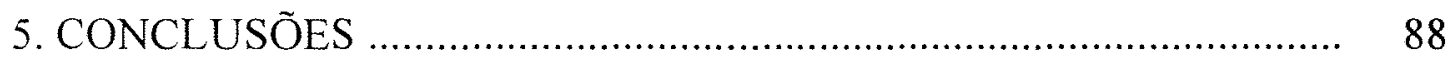

REFERÊNCIAS BIBLIOGRÁFICAS _............................................ 90 
DOSES DE NITROGÊNIO E DE POTÁSSIO PARA PRODUÇÃO, COMPOSIÇÃO E DIGESTIBILIDADE DOS CAPINS COASTCROSS 1 E TIFTON 85 EM UM LATOSSOLO VERMELHO-AMARELO

\section{Autora: Renata Aparecida Martim \\ Orientador: Prof. Dr. Francisco Antonio Monteiro}

\section{RESUMO}

O comportamento dos capins-bermuda Tifton 85 e Coastcross 1 submetidos a doses de nitrogênio e de potássio foi estudado para verificar a produção de matéria seca, as concentrações de $\mathrm{N}, \mathrm{K}, \mathrm{P}, \mathrm{Ca}$ e $\mathrm{Mg}$ na parte aérea e raízes, a relação haste:lâmina, teores de FDN e FDA e o coeficiente de DIVMS desses capins.

Os capins foram plantados em vasos contendo terra proveniente de um Latossolo Vermelho-Amarelo ácrico (Haplustox) cuja análise de solo inicial apresentou $\mathrm{P}=1,6 \mathrm{mg} \mathrm{dm}{ }^{-3} ;$ matéria orgânica=3,27 dag $\mathrm{kg}^{-1} ; \mathrm{pHCaCl}_{2}=4,7$; $\mathrm{K}=0,13 \mathrm{cmol}_{\mathrm{c}} \mathrm{dm}^{-3}$ e V\%=5,5\%. Foi utilizado o equivalente a $3,7 \mathrm{Mg}$ de calcário $\mathrm{ha}^{-1}$, com o objetivo de atingir a saturação por bases de $60 \%$. As doses de nitrogênio e de potássio foram, respectivamente, equivalentes a 20,100 e $180 \mathrm{~kg}$ de $\mathrm{N} \mathrm{ha}^{-1}$ e 15,75 e $135 \mathrm{~kg}_{\text {de }} \mathrm{K} \mathrm{ha}^{-1}$, aplicados após cada corte. O experimento foi conduzido no período de verão e foram realizados três cortes, sendo o primeiro após 44 dias de crescimento e o segundo e terceiro após 32 e 26 dias de cada corte, respectivamente, quando foram separadas as lâminas das hastes mais bainhas das plantas. Após o último corte foram coletadas as raizes.

A aplicação de doses de nitrogênio incrementou a produção de matéria seca da parte aérea e das raízes, aumentou as concentrações de nitrogênio e de 
magnésio e diminuiu a concentração de potássio e fósforo nas forrageiras. A produção de matéria seca da parte aérea também aumentou em função das doses de potássio, porém somente quando aliadas as mais altas doses de nitrogênio. A concentração de potássio aumentou enquanto as concentrações de nitrogênio, fósforo, cálcio e magnésio diminuíram com as doses de potássio. A relação haste:lâmina aumentou com a elevação das doses de potássio, mas diminuiu com as doses de nitrogênio. As concentrações de FDN e de FDA decresceram e o coeficiente de DIVMS foi incrementado com as doses de nitrogênio.

Não houve diferença significativa na produção de matéria seca entre os capins estudados. A concentração de nitrogênio e magnésio e fósforo na parte aérea do primeiro crescimento foram mais elevadas em Tifton 85 . O Coastcross 1 manifestou maior exigência de potássio e apresentou maior relação haste:lâmina do que o Tifton 85. O Tifton 85 apresentou maiores teores de FDN e FDA e maior DIVMS do que o Coastcross 1. 


\title{
NITROGEN AND POTASSIUM RATES FOR FORAGE YIELD, COMPOSITION AND DIGESTIBILITY OF COASTCROSS 1 AND TIFTON 85 IN AN OXISOL.
}

\author{
Author: Renata Aparecida Martim \\ Adviser: Prof. Dr. Francisco Antonio Monteiro
}

\section{SUMMARY}

The response of the bermudagrasses Tifton 85 and Coastcross 1 under doses of nitrogen and potassium was studied in order to verify the dry matter production and $\mathrm{N}, \mathrm{K}, \mathrm{P}, \mathrm{Ca}$ and $\mathrm{Mg}$ contents on the top parts and roots, stem:blade ratio, and $\mathrm{NDF}, \mathrm{ADF}$ and the in vitro dry matter digestibility (IVDMD).

The grasses were planted in pots with soil from a Haplustox which analysis

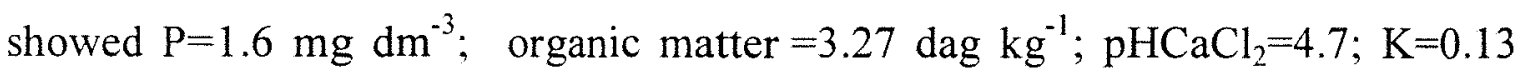
$\mathrm{cmol}_{\mathrm{c}} \mathrm{dm}^{-3}$ e V\%=5.5\%. It was used $3.7 \mathrm{Mg} \mathrm{ha}^{-1}$ of limestone to reach the bases saturation of $60 \%$. The nitrogen and potassium rates were, respectively, equivalent of 20,100 and $180 \mathrm{~kg}$ of $\mathrm{N} \mathrm{ha}^{-1}$ and 15,75 and $135 \mathrm{~kg}$ of K ha ${ }^{-1}$, applied after each harvest. The experiment was done during summer and three cuts were made, the first one after 44 days of growth and the second and third after 32 and 26 days after each cut, respectively. Blades were separated from the stems and sheath. In the last harvest the roots were collected.

The use of nitrogen rates increased dry matter production of top parts and roots, increased the concentration of nitrogen and magnesium and decreased the concentration of potassium and phosphorus in the grasses. The dry matter production of top parts also increased with potassium rates but when applied 
together with the highest rates of nitrogen. The concentration of potassium increased while the concentration of nitrogen, phosphorus, calcium and magnesium decreased with potassium rates. The stem:blade ration increased with potassium rates, but decreased with nitrogen rates. The concentration of NDF and ADF decreased and the IVDMD increased with nitrogen rates.

There was no significant difference between the grasses concerning the dry matter production. The concentration of nitrogen, magnesium and phosphorus on the top parts in the first harvest was higher in Tifton 85 than in Coastcross 1 . Coastcross 1 had higher requirement of potassium than Tifton 85, whereas Tifton 85 showed higher NDF, ADF contents and IVDMD than Coastcross 1. 


\section{INTRODUÇÃO}

As gramíneas do gênero Cynodon são cosmopolitas e apresentam morfologia e proficuidade muito variáveis. Após muitos anos de pesquisas com essas plantas foi possível encontrar cultivares forrageiros promissores e adaptados às mais diversas condições. Atualmente tem sido freqüentemente recomendadas como forrageiras para alimentação de eqüinos e bovinos em todo o mundo devido a qualidade e a palatabilidade dessas plantas. Diversos capins-bermuda são considerados como as forrageiras mais indicadas para fenação e, mais recentemente, para confecção de silagens pré-secadas.

O cultivar Coastcross 1 [Cynodon dactylon (L.) Pers. cv. Coastcross 1] é um dos mais importantes e mais conhecidos do gênero. Foi liberado em 1967, nos Estados Unidos da América, como forrageira de alta qualidade. A utilização dessas forrageiras e pesquisas envolvendo-as são mais freqüentes em países de clima mais quente do que no país de origem, devido a limitada tolerância ao frio demonstrada por essa gramínea. No Brasil, o Coastcross 1 é um dos capins desse gênero que vem sendo cultivado especialmente na região sudeste onde desenvolve-se bem e tem, evidenciado sua adaptação ao clima dessa região.

Liberado em 1992, o Tifton 85 [Cynodon spp.(reg. $n^{0}$ CV-20, PI 562699)] mostrou-se mais produtivo e de melhor qualidade que o Coastal (Cynodon dactylon) e é recomendado para a alimentação de eqüinos e bovinos. São escassos os trabalhos publicados, e apenas recentemente iniciaram-se no Brasil alguns trabalhos de pesquisa com o Tifton 85 e de outros novos cultivares de capimbermuda (Cynodon dactylon) e capim-estrela (Cynodon nlemfuënsis).

Tanto o Tifton 85 como o Coastcross 1 foram aceitos com base na sua digestibilidade, entre outros fatores. Na literatura observa-se que a digestibilidade 
e teor de fibras são indicados como um dos melhores parâmetros para avaliar a qualidade de uma forrageira. Sabe-se, porém, que fatores como a idade da planta, temperatura e fotoperíodo influenciam na digestibilidade das forrageiras. Com relação à adubação, existem alguns trabalhos de pesquisa revelando que a digestibilidade de um capim pode ser influenciada pela adubação nitrogenada, mas pouco se sabe sobre os demais nutrientes.

O nitrogênio tem sido freqüentemente apontado como o principal nutriente para promover o aumento da produção de uma forrageira. $\mathrm{O}$ equilíbrio entre a adubação potássica e a nitrogenada em uma pastagem certamente contribui para esse aumento de produção, principalmente quando a forragem é cortada e removida da área, exportando apreciável quantidade desse nutriente.

Nesse sentido procurou-se avaliar o Tifton 85 e o Coastcross 1 submetidos a níveis de fertilização nitrogenada e potássica num Latossolo Vermelho-Amarelo ácrico, observando-se a produção de matéria seca, digestibilidade, teores de fibra e a concentração dos nutrientes no solo e no tecido das plantas, além da relação haste:lâmina desses capins. 


\section{REVISÃO DE LITERATURA}

\subsection{Os capins-bermuda}

Os capins desse gênero (Cynodon) podem ser encontrados em todo o mundo e são conhecidos como plantas forrageiras e também como plantas daninhas, uma vez que algumas espécies são invasoras e de difícil controle. Apresentam grande variação morfológica, indo desde plantas com folhas muito pequenas até plantas robustas com folhas mais largas (Harlan e Wet, 1969).

No início do século XIX, nos Estados Unidos da América, o capimbermuda (Cynodon dactylon (L) Pers) era conhecido por ser uma planta daninha muito agressiva que se constituía em um sério problema para a cultura do algodão, e que resultava na sua denominação como "grama-do-demônio". A má reputação dessa gramínea mudou quando o cultivar Coastal foi liberado em 1943. O Coastal é um híbrido entre uma linhagem "daninha" da Georgia e uma introdução da África do Sul (não identificada). Porém, apesar de produtiva e resistente a algumas doenças, ela não é agressiva o suficiente para ser considera planta daninha (Harlan, 1970). Em 1947, Burton já descrevia o cultivar Coastal como a mais importante pastagem do sudeste norte-americano. Assim como o Coastal, outros cultivares surgiram, culminando, segundo Harlan (1970), numa revolução da produção de bovinos no sul dos Estados Unidos da América.

A necessidade de incrementar a produtividade animal resultou na busca por plantas de melhor qualidade, utilizando-se como um dos parâmetros a digestibilidade da matéria seca. Da seleção feita, principalmente considerando esse parâmetro, surgiu o Coastcross 1, liberado nos Estados Unidos da América em 1967 (Harlan, 1970). 
O Coastcross 1 foi difundido por diversos países e em alguns deles, como em Cuba, é considerado um dos mais promissores nas pastagens já introduzidas e é amplamente utilizado para a produção de bovinos (Herrera, 1979a). No Brasil, tem sido muito utilizado na região sudeste e é considerado uma das forrageiras mais utilizadas no Estado de São Paulo para alimentação de eqüinos (Haddad e Platzeck, 1986), além de ser uma boa alternativa para sistemas intensivos de produção de leite (Alvim et al., 1996).

Hibrido Fl estéril entre o Coastal e o acesso PI 255445 (originalmente coletado em Kitale, no Quênia), o Coastcross 1 apresentou consistentemente 11 a $12 \%$ maior digestibilidade do que o Coastal, resultando num ganho de peso $30 \%$ maior nas novilhas de leite consumindo Coastcross 1 do que naquelas que ingeriram a mesma quantidade do Coastal (Burton, 1972). Em 1967 o Coastcross 1 (ainda conhecido apenas como Coastal x Kenya 56\#14) mostrou, em média, digestibilidade da matéria seca (através do método dos sacos de nylon) de $601 \mathrm{~g} \mathrm{~kg}^{-1}$ enquanto que para o Coastal essa média foi de $535 \mathrm{~g} \mathrm{~kg}^{-1}$ (Burton et al., 1967).

A via fotossintética do Coastcross 1 é do tipo $\mathrm{C}_{4}$ (Beltran e Santa Cruz, 1985; Rumball, 1991). Esse cultivar não produz sementes, raramente produz rizomas e foi apontado como pouco susceptivel a doenças e ao ataque de insetos (Beltran e Santa Cruz, 1985). Na Espanha é considerado pouco resistente ao frio (Beltran e Santa Cruz, 1985) e, segundo Monson e Burton (1982), deve ser recomendado para regiões de menor latitude do que a região de Tifton nos Estados Unidos da América.

Em pesquisas realizadas em Nova Odessa-SP, o Coastcross 1 foi uma das mais produtivas dentre as 25 espécies e variedades de capins estudados (Alcântara et al., 1981), e mostrou boa distribuição estacional de produção (17\% de produção 
de matéria seca durante o inverno) quando comparado a uma média de $11 \%$ dos 25 capins estudados (Pedreira e Mattos, 1981).

Após o surgimento do Coastcross 1, outros cultivares de Cynodon foram desenvolvidos na busca por capins de melhor produtividade, qualidade e tolerância a pragas e doenças. Do cruzamento entre dois dos mais digestíveis capins-bermuda em 1984, foi liberado o híbrido Tifton 68 (Burton e Monson, 1984), que apesar de ser um Cynodon nlemfuënsis e não ter rizomas, é considerado pelos autores como um capim-bermuda e não uma grama-estrela. Esse capim apresentou em média digestibilidade in vitro da matéria seca (DIVMS) mais alta do que o Coastal e o Coastcross 1, mas demonstrou maior susceptibilidade ao frio.

Do cruzamento entre o Tifton 68 e um acesso da África do Sul (PI 290884) surgiu o Tifton 85 (Cynodon spp.), desenvolvido na "Coastal Plain Experimental Station", em Tifton, sul do Estado da Geórgia, Estados Unidos da América. Esse capim-bermuda produziu $26 \%$ mais matéria seca e foi $11 \%$ mais digestível que o Coastal, em experimento realizado em canteiros, e resultados de pesquisa mostraram também que é menos resistente ao frio do que o Coastal e o Tifton 44 (Burton et al., 1993). O Tifton 85 possui rizomas maiores, mas em menor número do que o Coastal e o Tifton 44 (Burton et al., 1993). Para Beltran e Santa Cruz (1985), a presença de rizomas pode aumentar a resistência da forrageira ao frio devido à maior quantidade de reservas orgânicas.

São poucas as informações sobre esses capins na literatura e apenas recentemente iniciaram-se trabalhos de pesquisa com o Tifton 85 e outros novos cultivares de Cynodon desenvolvidos nos Estados Unidos da América. Segundo Pedreira (1996), embora os capins como o Tifton 85 possam ser promissores para 
a pecuária brasileira, somente a execução de pesquisa científica poderá confirmar tal afirmação.

\subsection{Adubação nitrogenada e potássica e a produção de matéria seca}

A adubação é um dos fatores de maior influência no aumento da produção de uma gramínea forrageira estabelecida. Alvim et al. (1996) ressaltaram que o Coastcross 1 expressou boa produção de matéria seca na Zona da Mata de Minas Gerais e a adubação nitrogenada foi o fator mais importante na obtenção desse resultado. Schank et al. (1977), em estudos com o Coastcross 1 adubado com 20 $\mathrm{kg}$ de $\mathrm{N} \mathrm{ha}^{-1}$ por corte (total $200 \mathrm{~kg} \mathrm{ha}^{-1} \mathrm{ano}^{-1}$ ), obtiveram produções de até 25,4 $\mathrm{Mg} \mathrm{ha}^{-1}$ de matéria seca (com quatro semanas de intervalo entre cortes). Produção de matéria seca semelhante foi obtida por Lopes e Monks (1983) com a aplicação de $500 \mathrm{~kg}$ de $\mathrm{N} \mathrm{ha}^{-1}$, parcelada em três aplicações.

Em estudos com o Coastal a maior produção de matéria seca foi obtida com $670 \mathrm{~kg}$ de $\mathrm{N} \mathrm{ha}^{-1}$ ano $^{-1}$ e não houve diferença significativa entre os níveis de 670 e $1000 \mathrm{~kg} \mathrm{de} \mathrm{N} \mathrm{ha}^{-1}$ ano $^{-1}$ (Burton et al., 1963). Monson e Burton (1982) observaram que a produção de matéria seca de alguns capins-bermuda aumentou $18 \%$, em média, quando a aplicação foi de 336 para $672 \mathrm{~kg} \mathrm{de} \mathrm{N} \mathrm{ha}^{-1} \mathrm{ano}^{-1}$, aplicados em três vezes.

Hill et al. (1993), utilizando a adubação de 196, 21 e $81 \mathrm{~kg} \mathrm{ha}^{-1}$ ano $^{-1}$ (aplicada em duas vezes) de N, P, e K, respectivamente, encontraram produção de matéria seca de $18,6 \mathrm{Mg} \mathrm{ha}^{-1} \mathrm{ano}^{-1}$ (em quatro cortes) para o Tifton 85 e esta produção foi significativamente maior $(\mathrm{P}<0,05)$ que nos demais capins estudados (Tifton 68, Tifton 44 e Coastal). Num segundo experimento, quando as condições climáticas foram desfavoráveis (incluindo uma seca acentuada), a produção de 
matéria seca do Tifton 85 foi estatisticamente igual aos demais capins, com exceção do Tifton 44 que foi menor. Sollenberger et al. (1995) relataram que a produção de matéria seca não diferiu entre o Tifton 85 e a Florakirk (Cynodon dactylon) cultivados em canteiros e adubados com $200 \mathrm{~kg}^{\mathrm{de}} \mathrm{N} \mathrm{ha}^{-1}$ em quatro aplicações, mas superou a produção do Swannee (Cynodon dactylon) e Tifton 78.

Alvim et al. (1996) não observaram diferença significativa para produção de matéria seca entre as adubações nitrogenadas de 500 e $700 \mathrm{~kg} \mathrm{ha}^{-1} \mathrm{ano}^{-1}$ (com dosagem de $\mathrm{K}$ correspondendo a $65 \%$ dessa adubação) em Coastcross 1 , com freqüência de corte e adubação a cada quatro semanas. Em Cuba, a fertilização

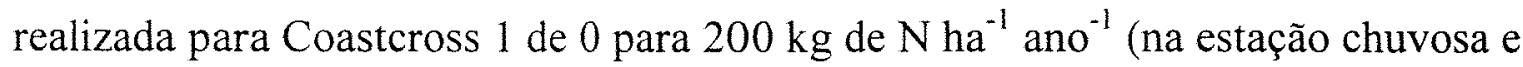
fracionada após cada corte) incrementou a produção de matéria seca de 0,8 para 2,8 $\mathrm{Mg} \mathrm{ha}^{-1}$ por corte (Herrera e Hernandez, 1985a).

Num experimento conduzido por Monson e Burton (1982), onde foram utilizados $672 \mathrm{~kg}$ de $\mathrm{N} \mathrm{ha}^{-1} \mathrm{ano}^{-1}$, em três aplicações e intervalo entre cortes de quatro semanas, o Coastcross 1 apresentou produção de matéria seca de 17,6 e $10,7 \mathrm{Mg} \mathrm{ha}^{-1}$ no primeiro e segundo ano, respectivamente, sendo que no primeiro ano as produções não diferiram significativamente $(\mathrm{P}>0,05)$ dos capins Coastal e Tifton 68. mas foram inferiores ao Coastal e superiores ao Tifton 68 no segundo ano.

Ferrari Júnior et al. (1993) observaram que a produção de matéria seca dobrou quando compararam o Coastcross 1 sem e com adubação de reposição ( $2 \%$ de $\mathrm{N}$ e $4 \%$ de $\mathrm{KCl}$ em equivalente em matéria seca removida), em áreas destinadas a produção de feno. Hernández e Cárdenas (1987) concluíram que deve-se recomendar $83 \mathrm{~kg} \mathrm{de} \mathrm{K} \mathrm{ha}^{-1}$, quando a adubação nitrogenada for de 300 $\mathrm{kg} \mathrm{ha}^{-1}$ em capim-estrela jamaicano (Cynodon nlemfuënsis). 
Num estudo realizado em Matão-SP com o Swannee Bermuda adubado com média de $165 \mathrm{~kg}$ de $\mathrm{K} \mathrm{ha}^{-1}$ foi observado que a maior produção média anual ocorreu com a adubação com 7,5:2,1:1 (N:P:S), na dose de nitrogênio de $600 \mathrm{~kg}$ $\mathrm{ha}^{-1} \mathrm{ano}^{-1}$ (Freitas e Jorge, 1982). Num estudo com o capim-estrela jamaicano, Pacheco et al. (1987) obtiveram o maior rendimento de matéria seca $(27,8 \mathrm{Mg}$ ha $^{-1}$ ano $^{-1}$ ) com a adubação anual de 400, 130 e $165 \mathrm{~kg} \mathrm{ha}^{-1}$ de N, P e K, respectivamente, dividida em sete aplicações, após cada corte.

Em Coastal, $95 \%$ da máxima produção de matéria seca foi obtida com a aplicação de $370 \mathrm{~kg}$ de $\mathrm{K} \mathrm{ha}^{-1}$, em quatro aplicações, durante a estação de crescimento (Eichhorn Junior e Hallmark, 1989). Cripps et al. (1989) obtiveram

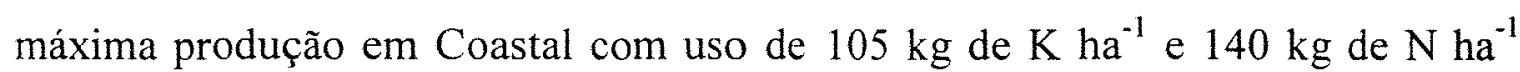
corte $^{-1}$. Em estudos com o mesmo capim, Adams et al. (1967) observaram que o

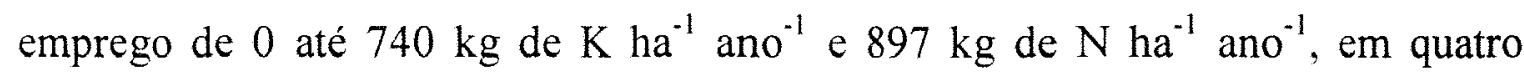
aplicações, incrementou a produção de matéria seca do capim em $66 \%$ e o teor do nutriente nas plantas em $300 \%$.

Monteiro et al. (1980), em estudos com o capim-colonião, concluíram que é imprescindível a aplicação contínua do potássio em pastagens adubadas com nitrogênio. Segundo Monteiro (1990), o potássio merece especial consideração onde a forragem é cortada e removida da área, devido as grandes quantidades extraídas desse nutriente. É necessária a realização de mais trabalhos de pesquisa com adubação potássica e o acompanhamento do teor e potássio no solo (Glória, 1986) e no tecido das forrageiras com o objetivo de obter melhores parâmetros para adubação. 


\subsection{Relação haste:lâmina nas forrageiras}

O estudo da relação entre lâminas e hastes é visto como um parâmetro importante na avaliação da qualidade das forrageiras. Segundo Rodrigues (1986), o consumo voluntário de forragem parece estar relacionado com a porcentagem de folhas de uma pastagem. Herrera (1979b) ressaltou que as folhas do Coastcross 1 possuem valor nutritivo superior às hastes.

Jordan et al. (1981) avaliaram a influência da proporção haste:folha na qualidade de uma pastagem de Coastcross 1 (cortado aos 28 dias de crescimento e adubado com $400 \mathrm{~kg}$ de $\mathrm{N} \mathrm{ha}^{-1}$ ano $^{-1}$ ) através da amostragem em separado de folhas e hastes, e posterior mistura de diferentes proporções das frações (com base na matéria seca) para análise. Enquanto a proporção de folhas na mistura efetuada passou de 0 para $100 \%$, o teor de nitrogênio aumentou linearmente de 19,6 até $30,6 \mathrm{~g} \mathrm{~kg}^{-1}$. O aumento na DIVMS também foi linear, variando de 429 até $627 \mathrm{~g}$ $\mathrm{kg}^{-1}$ com o aumento da porcentagem de folhas na matéria seca. Por outro lado, de acordo com Minson ${ }^{1}$, citado por Rodrigues (1986), a digestibilidade da matéria seca das folhas foi similar a das hastes de Digitaria decumbens, Chloris gayana, Panicum maximum e Panicum clandestinum. O mesmo foi relatado por Silveira (1970), em estudos com o capim-elefante, o qual também observou que a relação haste:folha desse capim foi de apenas 0,30 , com 51 dias de crescimento.

A relação haste:folha é bastante modificada com o avanço da idade dos capins. Vieira et al. (1980) observaram que a relação haste:folha do capimcolonião foi influenciada pela idade do capim, variando de 0,87 para 1,02 com 30

\footnotetext{
'MINSON, D.J. Effects of chemical and physical composition of herbage eaten upon intake. In: HACHER, J.B. (Ed.). Nutritional limits to animal production from pastures. Slough: CAB, 1982, p. 167-182.
} 
e 75 dias de crescimento, respectivamente. Burton et al. (1963), em estudos com o Coastal adubado com $670 \mathrm{~kg}$ de $\mathrm{N} \mathrm{ha}^{-1} \mathrm{ano}^{-1}$, observaram que a porcentagem de folhas na matéria seca diminuiu com a idade, sendo que essa porcentagem foi de $81,4 \%$ para cortes realizados a cada quatro semanas.

Em pesquisas com o capim-andropogon (Andropogon gayanus), guiné (Panicum maximum) e setária (Setaria anceps Stapf. ex Massey cv. Kazungula), Pinto et al. (1992) relataram que a relação haste:folha aumentou com a idade, sendo que essa relação foi em média de 0,81. Esses autores ressaltaram ainda que a relação haste:folha diminuiu com fertilização nitrogenada em capimandropogon.

Moura et al. (1975) obtiveram relação média de haste:folha de 0,73 nas amostras colhidas antes da fenação em capim-gordura (Melinis minutiflora) . Em pesquisas com o Coastcross 1, Ferrari Júnior et al. (1993), observaram que a porcentagem de folhas diminuiu significativamente $(\mathrm{P}<0,05)$ de 43,3 para $38,5 \%$ entre as áreas sem adubação e com adubação nitrogenada e potássica de reposição.

Herrera (1979a) encontrou em Coastcross 1 que a porcentagem de folhas foi incrementada com a adubação nitrogenada na estação seca, mas o mesmo não ocorreu na estação chuvosa. Herrera e Hernandez (1985a) observaram que o aumento da adubação nitrogenada de 0 para $400 \mathrm{~kg}$ de $\mathrm{N} \mathrm{ha}^{-1}$ diminuiu significativamente $(\mathrm{P}<0,05)$ a porcentagem de folhas de 45,3 para $44,7 \%$, respectivamente, em Coastcross 1 na estação chuvosa. Comportamento semelhante do mesmo capim foi obtido por Alvim et al. (1996) onde o relação folha:haste decresceu de 1,6 para 1,3, o que corresponde a um aumento na relação haste:folha de 0,62 para 0,77 , com a adubação nitrogenada de 0 até $750 \mathrm{~kg}$ de $\mathrm{N}$ $\mathrm{ha}^{-1}$ ano $^{-1}$, respectivamente, na estação chuvosa. 


\subsection{Composição química e digestibilidade das forrageiras}

O bom desempenho de um animal em pastejo é função do valor nutritivo do pasto e da taxa de ingestão dessa pastagem pelo animal. $O$ valor nutritivo de um pasto, no entanto, é função da sua composição química e da sua digestibilidade (Mott, 1959).

Variações na composição mineral de uma forrageira estão associadas à própria espécie ou ao cultivar e também são devidos a variações na composição botânica (Mott, 1959). Também variam com a idade, partes da planta, estações do ano e principalmente com a fertilização.

Conhecer as necessidades nutricionais para promover uma composição adequada de nutrientes nas forrageiras significa melhorar o seu desempenho e também garantir, de acordo com Corsi e Silva (1985), um suprimento adequado de minerais aos animais que consumirem essa forragem.

\subsubsection{Concentração de nitrogênio nos tecidos}

São inúmeros os fatores que influenciam na concentração do $\mathrm{N}$ em forrageiras. estando entre eles a própria espécie ou cultivar, fatores ambientais como a temperatura e umidade e a adubação. Diversos trabalhos tem demonstrado que o teor de nitrogênio decresce com a idade dos capins (Burton et al., 1963; Nascimento e Pinheiro, 1975; Silva et al., 1987; Palhano, 1990; Ferrari Júnior et al., 1993; Daiub, 1994; Alvim et al., 1996). Segundo Herrera e Hernandez (1987), a diminuição diária de proteína bruta em Coastcross 1 no período chuvoso foi de até 0,31 e 0,12 unidades percentuais na primeira e décima segunda semanas de crescimento, respectivamente. Em pesquisas com capim-bermuda cv. Coastal, 
Combellas et al.(1972), encontraram que o teor de $\mathrm{N}$ foi de $18,7 \mathrm{~g} \mathrm{~kg}^{-1}$ aos 39 dias de crescimento, e de 26,2 $\mathrm{g} \mathrm{kg}^{-1}$ com quatro semanas (Burton et al., 1963).

Os trabalhos revisados mostraram que a concentração do nitrogênio nos tecidos é bastante variada, mesmo em pesquisas conduzidas com uma mesma espécie ou cultivar. Aos 30 dias de crescimento, Palhano (1990) obteve concentração de nitrogênio de $27,0 \mathrm{~g} \mathrm{~kg}^{-1}$ em Coastcross 1 adubado $250 \mathrm{~kg}$ de K $\mathrm{ha}^{-1}$ ano $^{-1}$ e $250 \mathrm{~kg}$ de $\mathrm{N} \mathrm{ha}^{-1}$ ano $^{-1}$. Em condições semelhantes, Schank et al. (1977) obtiveram concentração de $\mathrm{N}$ igual a $24,2 \mathrm{~g} \mathrm{~kg}^{-1}$ para Coastcross 1 . Resultados muito inferiores para o mesmo capim foram revelados por Alcântara et al. (1981), onde teor de nitrogênio obtido foi de apenas $10,0 \mathrm{~g} \mathrm{~kg}^{-1}$, com 60 dias de crescimento e após ter sido adubado com $200 \mathrm{~kg}_{\text {de }} \mathrm{N} \mathrm{ha}^{-1}$ ano $^{-1}$.

Utilizando adubação nitrogenada de 400 e $200 \mathrm{~kg} \mathrm{ha}^{-1}$ no primeiro e segundo ano, respectivamente, Pedreira e Mattos (1981) obtiveram teores médios de nitrogênio de $15,8 \mathrm{~g} \mathrm{~kg}^{-1}$ para $\mathrm{o}$ Coastcross 1 , não diferenciando significativamente $(\mathrm{P}<0,05)$ de outras 21 espécies ou variedades de capins tropicais estudadas no mesmo periodo. No Estado de São Paulo, o teor médio de nitrogênio encontrado em pastagens de Cynodon dactylon (a idade não foi informada) foi de $18,3 \mathrm{~g} \mathrm{~kg}^{-1}$ (Gallo et al., 1974).

Em pesquisas com fenos de capim-colonião (Panicum maximum), jaraguá (Hyparrhenia rufa) e braquiária (Brachiaria decumbens), Gomide et al. (1987) observaram que os teores de nitrogênio foram de 13,$3 ; 10,4$ e $4,1 \mathrm{~g} \mathrm{~kg}^{-1}$, respectivamente. Em capim-colonião cv.Tobiatã, França e Haag (1985) observaram sintomas visuais de deficiência quando o teor de $\mathrm{N}$ foi de $10,0 \mathrm{~g} \mathrm{~kg}^{-1}$. Segundo Malavolta et al. (1986), os sintomas de deficiência de nitrogênio em gramíneas forrageiras são caracterizados pela diminuição na produção, menor perfilhamento e clorose nas folhas mais velhas. 
Os estudos com forrageiras em países de clima temperado normalmente revelam maiores concentrações de nitrogênio do que aqueles realizados em regiões de clima tropical. Utley et al. (1971), comparando cultivares de capimbermuda, observaram que o teor de nitrogênio em Coastcross $1\left(28,0 \mathrm{~g} \mathrm{~kg}^{-1}\right)$ foi maior do que em Coastal $\left(26,9 \mathrm{~g} \mathrm{~kg}^{-1}\right)$ com quatro semanas de crescimento e adubado com 45:6,5:25 (N:P:K kg ha ${ }^{-1}$ ) por corte. A concentração de nitrogênio do Coastcross $1\left(33,0 \mathrm{~g} \mathrm{~kg}^{-1}\right)$ foi significativamente $(\mathrm{P}<0,05)$ superior ao Callie $\left(31,7 \mathrm{~g} \mathrm{~kg}^{-1}\right)$, Tifton $68\left(31,5 \mathrm{~g} \mathrm{~kg}^{-1}\right)$, Midland $\left(28,8 \mathrm{~g} \mathrm{~kg}^{-1}\right)$, Coastal $\left(27,5 \mathrm{~g} \mathrm{~kg}^{-1}\right) \mathrm{e}$ Tifton $44\left(27,2 \mathrm{~g} \mathrm{~kg}^{-1}\right)$ nas pesquisas relatadas por Monson e Burton (1982). Pedreira (1995) observou que o teor de nitrogênio em Florakirk foi em média maior $\left(21,1 \mathrm{~g} \mathrm{~kg}^{-1}\right)$ do que em Tifton $85\left(19,5 \mathrm{~g} \mathrm{~kg}^{-1}\right)$, adubados com $150 \mathrm{~kg}$ de $\mathrm{N}$ $\mathrm{ha}^{-1}$. Em estudos com o Tifton 85 , Hill et al. (1993) obtiveram $22,6 \mathrm{~g} \mathrm{~kg}^{-1}$ como média no teor de nitrogênio desse capim.

Os dados obtidos na literatura mostram que a concentração do nitrogênio nos tecidos das plantas forrageiras é influenciada pela fertilização nitrogenada. Porém, segundo Whitehead (1995), quando o nitrogênio é aplicado em baixa dosagem numa pastagem deficiente, há um aumento na produção mas a concentração do nutriente na planta é pouco alterada.

Bufarah et al. (1982), em estudos com Coastcross 1 em solo mal-drenados, relataram que o teor de nitrogênio foi de 9,6 e $11,8 \mathrm{~g} \mathrm{~kg}^{-1}$, respectivamente, em pasto sem e com adubação nitrogenada de $70 \mathrm{~kg} \mathrm{ha}^{-1} \mathrm{ano}^{-1}$. Ferrari Júnior et al. (1993) obtiveram concentração de nitrogênio significativamente $(\mathrm{P}<0,05)$ menor na forrageira das áreas destinadas à produção de feno de Coastcross 1 com 42 dias de crescimento e que não receberam adubação $\left(19,7 \mathrm{~g} \mathrm{~kg}^{-1}\right)$ do que nas áreas que receberam adubação $\left(26,8 \mathrm{~g} \mathrm{~kg}^{1-}\right)$ de reposição de $2 \%$ e $4 \%$ do material colhido como $\mathrm{N} \mathrm{e} \mathrm{KCl}$, respectivamente. Também foi verificado aumento de produção 
desse capim com a adubação de reposição. Almeida e Monteiro (1995) observaram estreita relação entre as doses de nitrogênio testadas e a produção de matéria seca de lâminas nos três cortes realizados em Coastcross 1 cultivado em vasos, sendo que o mesmo foi observado para produção de matéria seca de caule mais bainhas apenas no primeiro crescimento.

O teor de nitrogênio em Coastcross 1 aumentou significativamente $(\mathrm{P}<0,05)$ de 16,3 para $18,9 \mathrm{~g} \mathrm{~kg}^{-1}$ sem e com adubação de $400 \mathrm{~kg} \mathrm{de} \mathrm{N} \mathrm{ha}^{-1}$ ano $^{-1}$ durante a estação chuvosa. Na estação seca, no entanto, a concentração de nitrogênio nesse capim atingiu $24,4 \mathrm{~g} \mathrm{~kg}^{-1}$ nos pastos adubados (Herrera, 1979a). Da mesma forma, Herrera (1979b) obteve teor de nitrogênio em Coastcross 1 de 16,0 e $20,7 \mathrm{~g} \mathrm{~kg}^{-1}$ para aplicações de nitrogênio de 0 e $40 \mathrm{~kg} \mathrm{ha}^{-1}$ corte $^{-1}$, sendo que os teores mais baixos foram obtidos na estação úmida, provavelmente devido ao efeito de diluição.

Herrera e Hernandez (1985b) mostraram que o aumento na adubação nitrogenada de 0 para $400 \mathrm{~kg} \mathrm{ha}^{-1}$ ano $^{-1}$ incrementou o teor de nitrogênio nos tecidos do Coastcross 1 de 14,9 para $20,6 \mathrm{~g} \mathrm{~kg}^{-1}$, na estação chuvosa. Comportamento semelhante foi observado por Cáceres et al. (1989) em pesquisas com a mesma forrageira. Coto et al. (1990) observaram um incremento no teor de nitrogênio em Coastcross 1 de 10,9 para $12,7 \mathrm{~g} \mathrm{~kg}^{-1}$ na estação chuvosa quando a adubação foi de 0 e $400 \mathrm{~kg} \mathrm{ha}^{-1} \mathrm{ano}^{-1}$, respectivamente. Alvim et al. (1996) observaram com o Coastcross 1 que o teor de $\mathrm{N}$ aumentou com a adubação nitrogenada, sendo que para freqüencia de cortes de quatro semanas o teor foi de

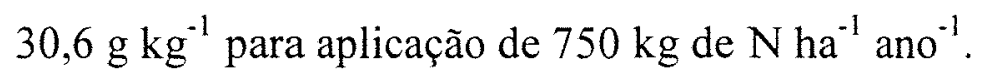

O Coastcross 1 apresentou concentrações mais elevadas de nitrogênio nos tecidos no trabalho realizado por Monson e Burton (1982), onde o teor médio de nitrogênio nesse capim com quatro semanas de crescimento incrementou de 27,5 


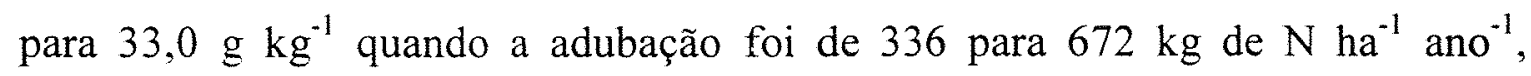
respectivamente. Valores ainda mais elevados foram obtidos por Lopes e Monks (1983) no primeiro ano do experimento, condição em que o maior teor de

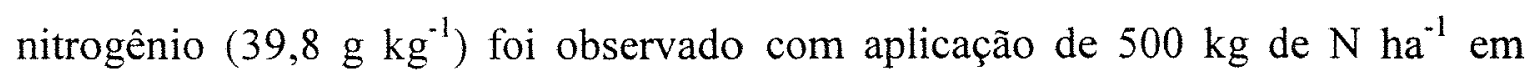
Coastcross 1. No segundo ano, esse teor foi de apenas $16,2 \mathrm{~g} \mathrm{~kg}^{-1}$ para o nível mais alto de nitrogênio aos 30 dias de crescimento (Monks e Lopes, 1983).

Em estudos com diversas seleções de capim-bermuda, Burton (1947) observou que a concentração de nitrogênio capim-bermuda aumentou de $10,3 \mathrm{~g}$ $\mathrm{kg}^{-1}$ para $12,3 \mathrm{~g} \mathrm{~kg}^{-1}$ com adubação de 0 e $40 \mathrm{~kg}$ de $\mathrm{N} \mathrm{ha}^{-1}$ corte $^{-1}$, respectivamente. Burton e Devane (1952), trabalhando com um cultivar de Cynodon dactylon, observaram que o teor de nitrogênio incrementou de 11,2 para $20,8 \mathrm{~g} \mathrm{~kg}^{-1}$, com aplicação de 56 para $450 \mathrm{~kg}_{\text {de N ha }}{ }^{-1}$ ano $^{-1}$. Caro-Costas et al. (1976) obtiveram variação média no teor de nitrogênio de 35,2 para $38,9 \mathrm{~g} \mathrm{~kg}^{-1}$ em capim-estrela (Cynodon nlemfuënsis) com a fertilização com nitrogênio e potássio variando de 270 e 150 até 670 e $370 \mathrm{~kg} \mathrm{ha}^{-1}$, respectivamente. Em pesquisas com Swannee. Freitas e Jorge (1982) relataram que a concentração de nitrogênio variou de 11,5 para $24,5 \mathrm{~g} \mathrm{~kg}^{-1}$ com incremento na adubação de 0 para $600 \mathrm{~kg}$ de $\mathrm{Nha}^{-1}$.

Apesar da grande influência da adubação nitrogenada na produção de uma forrageira. os demais nutrientes devem ser fornecidos em quantidades suficientes para o bom desenvolvimento da planta. Com relação ao equilíbrio entre o nitrogênio e o potássio, Hernández e Cárdenas (1990) estudaram quatro doses de nitrogênio $\left(0,150,300\right.$ e $450 \mathrm{~kg}$ de $\left.\mathrm{N} \mathrm{ha}^{-1}\right)$ e três de potássio $(0,83,166 \mathrm{~kg}$ de $\mathrm{K}$ $\mathrm{ha}^{-1}$ ) e concluíram que a adubação que produziu maior estabilidade nos rendimentos de capim-estrela jamaicano foi de 300 e $166 \mathrm{~kg} \mathrm{ha}^{-1}$, de nitrogênio e potássio, respectivamente. Também, o teor de nitrogênio foi influenciado pela 
adubação potássica em estudos com Cynodon dactylon efetuados por Mesa et al. (1989) os quais obtiveram decréscimo no teor de nitrogênio com a aplicação de doses de potássio variando de 50 até $400 \mathrm{~kg} \mathrm{de} \mathrm{K} \mathrm{ha}^{-1}$, em Cynodon dactylon $\mathrm{cv}$. 68. Por outro lado, Eichhorn e Nelson (1988) não constataram aumento na concentração de nitrogênio do Coastal recebendo doses de potássio de até $551 \mathrm{~kg}$ de $\mathrm{K} \mathrm{ha}^{-1}$.

\subsubsection{Concentração de potássio nos tecidos e no solo}

A exemplo do nitrogênio, a concentração de potássio nos tecidos também é influenciado por diversos fatores. Com relação aos diferentes cultivares, Gonzalez et al. (1983) observaram diferença significativa entre o teor médio de potássio obtido no Coastal $\left(12,0 \mathrm{~g} \mathrm{~kg}^{-1}\right)$ quando comparado ao Coastcross $1\left(14,8 \mathrm{~g} \mathrm{~kg}^{-1}\right)$ utilizando uma adubação básica de potássio de $83 \mathrm{~kg} \mathrm{de} \mathrm{K} \mathrm{ha}^{-1}$. Em Swannee, sem adubação, o teor médio de potássio foi de $11,7 \mathrm{~g} \mathrm{~kg}^{-1}$ (Gomide et al., 1969). Hernández e Cárdenas (1990) obtiveram teor máximo de potássio em capimestrela jamaicano de $19,7 \mathrm{~g} \mathrm{~kg}^{-1}$ com a adubação potássica de $165 \mathrm{~kg} \mathrm{de} \mathrm{K} \mathrm{ha}^{-1}$. O valor médio de potássio nos capins-bermuda Alicia e Coastal foi de $17,8 \mathrm{~g} \mathrm{~kg}^{-1}$, adubados com $340 \mathrm{~kg}$ de $\mathrm{N}$ e $115 \mathrm{~kg}$ de $\mathrm{K} \mathrm{ha}^{-1}$ durante a estação de crescimento e amostragens feitas a cada duas semanas (Kappel et al., 1985).

O nível crítico de potássio em Coastcross 1 encontrado por Gonzalez e Oilda (1982) foi de 26,0 $\mathrm{g} \mathrm{kg}^{-1}$. Eichhorn Junior e Hallmark (1989) observaram que a produção de matéria seca de Coastal decresceu quando a concentração de potássio foi menor que $22,4 \mathrm{~g} \mathrm{~kg}^{-1}$. Cripps et al. (1989) obtiveram máxima produção quando a concentração de potássio nos tecidos desse capim foi de $22,0 \mathrm{~g}$ $\mathrm{kg}^{-1}$. Mesa et al. (1989) encontraram nível crítico de potássio de $36,4 \mathrm{~g} \mathrm{~kg}^{-1}$ para o 
Tifton 68. No Brasil, o teor médio de potássio encontrado em amostras de pastagens de Cynodon dactylon no Estado de São Paulo foi de $18,8 \mathrm{~g} \mathrm{~kg}^{-1}$ (Gallo et al. , 1974). França e Haag (1985) observaram sintomas visuais de deficiência de potássio em Tobiatã quando a teor nas folhas foi menor do que $4,7 \mathrm{~g} \mathrm{~kg}^{-1}$.

Em estudos com Coastcross 1 em solos mal drenados, Bufarah et al. (1982) encontraram teor de potássio de $10,3 \mathrm{~g} \mathrm{~kg}^{-1}$. Palhano (1990) encontrou teor médio para o mesmo capim de $17,0 \mathrm{~g} \mathrm{~kg}^{-1}$ aos 30 dias de crescimento, utilizando adubação de $250 \mathrm{~kg}_{\text {de }} \mathrm{N}_{\text {ha }}{ }^{-1}$ e $250 \mathrm{~kg}_{\text {de }} \mathrm{K} \mathrm{ha}^{-1}$, e também observou também que o teor de potássio na planta diminuiu significativamente $(\mathrm{P}<0,05)$ com a idade. Gomide et al. (1969) também observaram que o teor de potássio diminuiu de 14,2 para 3,0 $\mathrm{g} \mathrm{kg}^{-1}$ com o avanço da idade de quatro para 36 semanas em seis espécies de capins (Melinis minutiflora, Digitaria decumbens, Pennisetum purpureum, Pennisetum clandestinum, Cynodon dactylon e Panicum maximum) cultivadas em solo arenoso de Minas Gerais.

Resultados de trabalhos de pesquisa tem mostrado que uma nutrição adequada de potássio aumenta a resistência das plantas a doenças. Richardson e Croughan (1989), em pesquisas com os cultivares Grazer e Tifton 78, observaram aumento da susceptibilidade ao ataque de Helminthosporium cynodontis quando o teor de potássio nos tecidos foi menor $25,0 \mathrm{~g} \mathrm{~kg}^{-1}$. Também o Coastal mostrou sintomas foliares da mesma doença quando as plantas não foram supridas com o potássio (Matocha e Smith, 1980).

A adubação nitrogenada de 0 até $400 \mathrm{~kg} \mathrm{ha}^{-1}$ também influenciou na concentração de potássio em Coastcross 1 no trabalho de Herrera e Hernandez (1985b), onde houve aumento linear $(\mathrm{P}<0,01)$ de 5,0 para 9,0 $\mathrm{g} \mathrm{kg}^{-1}$ e de 11,0 para $19,0 \mathrm{~g} \mathrm{~kg}^{-1}$ na estação seca e chuvosa, respectivamente. O mesmo foi observado por Gonzalez et al. (1983), em pesquisas com doses de nitrogênio de 0, 200 e 400 
$\mathrm{kg}$ de $\mathrm{N} \mathrm{ha}^{-1}$ ano $^{-1}$, as quais resultaram em uma variação $(\mathrm{P}<0,05)$ no teor de potássio em Coastcross 1 de 14,2; 17,6 e 12,7 $\mathrm{g} \mathrm{kg}^{-1}$; respectivamente, na estação seca.

Aspiolea e Díaz (1981) observaram que houve aumento no conteúdo de potássio nos tecidos de Coastcross 1 à medida que incrementaram as doses de potássio e nitrogênio, onde os maiores níveis utilizados foram de 250 e $400 \mathrm{~kg}$ $\mathrm{ha}^{-1}$ ano $^{-1}$, respectivamente. Eichhorn Junior e Nelson (1988) observaram aumento de 7,7 para $22,4 \mathrm{~g} \mathrm{~kg}^{-1}$ em Coastal sem adubação e com adubação de $558 \mathrm{~kg}$ de K ha $^{-1}$ ano $^{-1}$, respectivamente.

Em pesquisas com Coastal utilizando doses de adubação variando de 84 até $672 \mathrm{~kg} \mathrm{ha}^{-1}$ da proporção 9,1:1:5,7 (N:P:K), Day e Parker (1985) constataram que nas três primeiras doses de nitrogênio utilizadas as plantas não foram adequadamente supridas em potássio. Porém, para a aplicação mais elevada nitrogênio (672 kg de $\mathrm{N} \mathrm{ha}^{-1}$ ), houve consumo de luxo de potássio pelas plantas. O teor de potássio nas plantas variou de $16,3 \mathrm{~g} \mathrm{~kg}^{-1}$ para $19,0 \mathrm{~g} \mathrm{~kg}^{-1}$ para o menor e maior nível de nitrogênio utilizado, respectivamente.

No solo, Hass (1986) relatou que para cada aumento de $0,10 \mathrm{cmol}_{c} \mathrm{dm}^{-3}$ no teor de potássio no solo foi observado um decréscimo de $1,0 \mathrm{~g} \mathrm{~kg}^{-1}$ na concentração de nitrogênio na parte aérea do Coastcross 1. Porém acrescentou que não foi observada correlação significativa entre o teor de potássio nas folhas com seus correspondentes no solo.

Nelson et al. (1983) concluíram que o potássio no solo pode se exaurir quando ocorrem altas produções do cultivar Coastal, mesmo para o mais alto nível de potássio utilizado no trabalho (278 $\mathrm{kg}$ de $\left.\mathrm{K} \mathrm{ha}^{-1}\right)$. Cripps et al. (1989), trabalhando com os níveis $0,140,279$ e $419 \mathrm{~kg}$ de $\mathrm{K} \mathrm{ha}^{-1}$, observaram que houve 
incremento do conteúdo de potássio no solo somente quando a mais alta dose do nutriente foi utilizada.

Segundo Eichhorn Junior e Amarcher (1987-88) a máxima produção de Coastal submetido a níveis de potássio, foi obtida quando o potássio trocável no solo $(0-15 \mathrm{~cm})$ era de $50 \mathrm{mg} \mathrm{dm}^{-3}$.

\subsubsection{Concentração de fósforo nos tecidos}

O fósforo é usualmente o nutriente mais limitante na fase de estabelecimento das forrageiras devido a escassez desse nutriente nos solos brasileiros. Gallo et al. (1974) revelaram que esse teor em pastagens de Cynodon dactylon foi de $1,9 \mathrm{~g} \mathrm{~kg}^{-1}$. Pedreira e Mattos (1981) obtiveram teor de $2,5 \mathrm{~g} \mathrm{~kg}^{-1}$ em Coastcross 1 adubado com $44 \mathrm{~kg} \mathrm{de} \mathrm{P} \mathrm{ha}^{-1}$ ano $^{-1}$. O mesmo foi observado por Palhano (1990), em estudos com a mesma forrageira aos 30 dias de crescimento. Por outro lado, Bufarah et al. (1982) obtiveram teor de fósforo de $1,5 \mathrm{~g} \mathrm{~kg}^{-1} \mathrm{em}$ Coastcross 1. Em capim-bermuda Alicia e Coastal, o teor médio de P encontrado por Kappel et al. (1985) foi de $4,5 \mathrm{~g} \mathrm{~kg}^{-1}$

Segundo Gutierrez et al. (1980), o teor de fósforo em Coastcross 1 decresceu de 5,2 $\mathrm{g} \mathrm{kg}^{-1}$ para $2,6 \mathrm{~g} \mathrm{~kg}^{-1}$ com o avanço da idade de três para oito semanas, respectivamente, em pasto adubado com $65 \mathrm{~kg}_{\text {de }} \mathrm{P} \mathrm{ha}^{-1} \mathrm{ano}^{-1}$. Gomide et al. (1969) relataram que houve diminuição $(\mathrm{P}<0,01)$ na concentração de $\mathrm{P}$ com o avanço da idade e entre as espécies estudadas. Para o Swannee a concentração de $\mathrm{P}$ observada foi de $2,2 \mathrm{~g} \mathrm{~kg}^{-1}$ com quatro semanas de crescimento. Aos 39 dias de crescimento, Combellas et al. (1972) também obtiveram concentração de fósforo de $2,2 \mathrm{~g} \mathrm{~kg}^{-1}$ em Coastal. 
A adubação nitrogenada tende a diminuir o teor de fósforo em Coastcross 1. Gonzalez et al. (1983) observaram que o incremento na adubação nitrogenada de 0 para $400 \mathrm{~kg}_{\text {de }} \mathrm{N} \mathrm{ha}^{-1}$ (adubação básica contendo 22 e $83 \mathrm{~kg} \mathrm{ha}^{-1}$ ano $^{-1}$ de $\mathrm{P}$ e $\mathrm{K}$ ) diminuiu $(\mathrm{P}<0,05)$ o teor de fósforo de 3,8 para $3,2 \mathrm{~g} \mathrm{~kg}^{-1}$, respectivamente, durante a estação seca. Comportamento semelhante para o mesmo capim foi relatado por Herrera e Hernandez (1985b), com diminuição do teor de fósforo $(\mathrm{P}<0,001)$ de 3,4 para $3,0 \mathrm{~g} \mathrm{~kg}^{-1}$ na estação chuvosa para adubação nitrogenada de 0 e $400 \mathrm{~kg}$ de $\mathrm{N} \mathrm{ha}^{-1}$ ano $^{-1}$. Por outro lado, Caro-Costas et al. (1976) não obtiveram variação no teor de fósforo em capim-estrela utilizando a adubação com $\mathrm{N}$ e $\mathrm{K}$ de 270 e 150 até 670 e $370 \mathrm{~kg} \mathrm{ha}^{-1}$, respectivamente.

O teor máximo $\left(1,7 \mathrm{~g} \mathrm{~kg}^{-1}\right)$ e mínimo $\left(0,8 \mathrm{~g} \mathrm{~kg}^{-1}\right)$ de fósforo foram obtidos por Freitas e Jorge (1982) mediante aplicação de 350 e $0 \mathrm{~kg}$ de $\mathrm{P} \mathrm{ha}^{-1}$ ano $^{-1} \mathrm{em}$ Swannee cultivado em Latossolo Vermelho-Amarelo em Matão-SP. Segundo Monteiro et al. (1995a), a concentração de fósforo nas lâminas apresentou correlação positiva com a produção de matéria seca de Brachiaria decumbens.

\subsubsection{Concentração de cálcio nos tecidos}

Estudos com o Coastcross 1 revelaram teores de cálcio de $3,0 \mathrm{~g} \mathrm{~kg}^{-1}$ (Pedreira e Mattos, 1981); $2.7 \mathrm{~g} \mathrm{~kg}^{-1}$ (Bufarah et al., 1982); $2,4 \mathrm{~g} \mathrm{~kg}^{-1}$ (Palhano, 1990) com 30 dias e $4,1 \mathrm{~g} \mathrm{~kg}^{-1}$ (Combellas et al., 1972), com 39 dias de crescimento.

Gomide et al. (1969) observaram teor médio de cálcio em Swannee de 3,6 $\mathrm{g} \mathrm{kg}^{-1}$ com quatro semanas de idade. Gallo et al. (1974) observaram que o teor médio foi de $6,0 \mathrm{~g} \mathrm{~kg}^{-1}$ em amostras de Cynodon dactylon no Estado de São 
Paulo. A concentração média desse nutriente nos capins-bermuda Alicia e Coastal no sul dos Estados Unidos da América foi de $3,8 \mathrm{~g} \mathrm{~kg}^{-1}$ (Kappel et al., 1985).

Gonzalez et al. (1983) observaram que a adubação nitrogenada (0 até 400 $\mathrm{kg}$ de $\left.\mathrm{N} \mathrm{ha}^{-1}\right)$ incrementou $(\mathrm{P}<0,05)$ o teor de cálcio em Coastcross 1 de 4,4 para $5,0 \mathrm{~g} \mathrm{~kg}^{-1}$, respectivamente, sendo semelhantes aos encontrados nos demais capins do gênero Cynodon. Na estação chuvosa, Herrera e Hernandez (1985b), nas mesmas condições, observaram que o teor de cálcio aumentou $(\mathrm{P}<0,05)$ de 4,4 para $4,9 \mathrm{~g} \mathrm{~kg}^{-1}$.

Não foi verificada variação no teor de cálcio em capim-estrela quando a adubação com nitrogênio e potássio foram de 270 e 150 até 670 e $370 \mathrm{~kg} \mathrm{ha}^{-1}$, respectivamente (Caro-Costas et al., 1976).

Resultados experimentais tem demonstrado que a absorção do potássio pode interferir na absorção de cálcio pelas plantas. Mesa et al. (1989) observaram que o teor de cálcio ajustou-se a uma regressão quadrática, apresentando ponto mínimo de $200 \mathrm{~kg}$ de $\mathrm{K} \mathrm{ha}^{-1}$ em Cynodon dactylon. O aumento na fertilização potássica também induziu a um decréscimo no teor de cálcio nos tecidos de Coastal (Cripps et al., 1989). Por outro lado, em estudos com o mesmo capim, Eichhorn e Nelson (1988) relataram que o teor de cálcio não foi alterado com a adubação potássica de até $560 \mathrm{~kg}$ de $\mathrm{K} \mathrm{ha}^{-1}$ ano $^{-1}$.

\subsubsection{Concentração de magnésio nos tecidos}

Kappel et al. (1985), em estudos com os capins-bermuda Coastal e Alicia, relataram que o teor médio de magnésio encontrado foi de $2,2 \mathrm{~g} \mathrm{~kg}^{-1}$. Em Cynodon dactylon amostrado no Estado de São Paulo, Gallo et al. (1974) observaram valores médios de $2,3 \mathrm{~g} \mathrm{~kg}^{-1}$. Num estudo com o Coastcross 1 , 
Palhano (1990) encontrou teor de magnésio de $3,8 \mathrm{~g} \mathrm{~kg}^{-1}$ aos 30 dias de crescimento. Gomide et al. (1969) observaram que o teor de magnésio em Swannee foi de $3,1 \mathrm{~g} \mathrm{~kg}^{-1}$ com quatro semanas, e que decresceu com o avançar da idade do capim.

Gonzalez et al. (1983) efetuaram estudos com o Coastcross $1 \mathrm{e}$ descobriram que a concentração de magnésio incrementou $(\mathrm{P}<0,05)$ de 1,7 para $2,1 \mathrm{~g} \mathrm{~kg}^{-1}$ durante a estação seca quando a dose de nitrogênio utilizada passou de 0 para $400 \mathrm{~kg}_{\text {de }} \mathrm{N} \mathrm{ha}^{-1} \mathrm{ano}^{-1}$, respectivamente. Com o mesmo capim e idêntica adubação, Herrera e Hernandez (1985b) observaram aumento linear $(\mathrm{P}<0,01)$ no teor de magnésio de 2,0 para 3,0 $\mathrm{g} \mathrm{kg}^{-1}$ na estação seca e chuvosa.

Trabalhos de pesquisa tem comprovado que existe antagonismo entre o potássio e o magnésio, especialmente para níveis elevados de adubação potássica. Segundo Mesa et al. (1989), o teor de magnésio ajustou-se a um modelo de

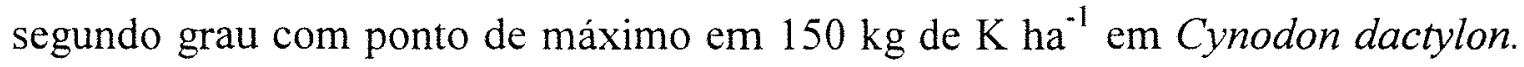
$\mathrm{O}$ teor de magnésio decresceu significativamente $(\mathrm{P}<0,01)$ de 2,3 para $1,7 \mathrm{~g} \mathrm{~kg}^{-1}$ com a adubação potássica de até $560 \mathrm{~kg}$ de $\mathrm{K} \mathrm{ha}^{-1}$ em Coastal (Eichhorn e Nelson, 1988).

\subsubsection{Fibra em detergente ácido (FDA) e detergente neutro (FDN)}

Segundo Van Soest (1994), o sistema do "detergente" é um procedimento que visa determinar a matriz de parede celular insolúvel e estimar a maioria dos seus subcomponentes. O resíduo de fibra resultante da utilização do detergente neutro, ou seja, o FDN (fibra em detergente neutro) é constituído de celulose, hemicelulose e lignina. Já o FDA (fibra em detergente ácido) é constituído principalmente de celulose, mas também de lignina, cutina, nitrogênio indigestível 
e sílica. Segundo esse autor, o FDA está mais associado com a digestibilidade dos alimentos, enquanto que o FDN com a ingestão, taxa de enchimento e passagem do alimento no sistema digestivo em ruminantes.

Existe uma grande variação no teor de FDN e FDA obtidos nas forrageiras. Sabe-se que esses teores são influenciados por diversos fatores como, por exemplo, os ambientais, idade de corte e espécie ou cultivar. O teor de FDA encontrado em Orchardgrass (Dactylis glomerata, L.) foi de $344 \mathrm{~g} \mathrm{~kg}^{-1}$, já no Coastal esse valor foi de $400 \mathrm{~g} \mathrm{~kg}^{-1}$ (Reid et al., 1967a; Combellas et al., 1972). Olubajo et al. (1974) constataram teores de FDA de 436; 425; 426; $437 \mathrm{~g} \mathrm{~kg}^{-1}$, respectivamente em Cynodon plectostachyum, Cynodon Ib8, Pennisetum purpureum, Panicum maximum com seis semanas de crescimento. Caielli et al. (1979) obtiveram teores de FDN e FDA em capim gordura, em média, de 815 e $494 \mathrm{~g} \mathrm{~kg}^{-1}$, respectivamente.

O teor de FDN encontrado por Hill et al. (1993) para o Tifton 85 adubado com $250 \mathrm{~kg}$ de $\mathrm{N} \mathrm{ha}^{-1} \mathrm{ano}^{-1}$ foi de $730 \mathrm{~g} \mathrm{~kg}^{-1}$, valor esse inferior ao obtido por Pedreira (1995) que observou teores de FDN de $808 \mathrm{~g} \mathrm{~kg}^{-1}$ para Tifton 85 e 772 $\mathrm{g} \mathrm{kg}^{-1}$ para Florakirk adubados com $150 \mathrm{~kg} \mathrm{de} \mathrm{N} \mathrm{ha}^{-1}$ ano $^{-1}$.

Com quatro semanas de crescimento e utilizando uma adubação com $\mathrm{N}: \mathrm{P}: \mathrm{K}$ de 45:6,5:25 ( $\left.\mathrm{kg} \mathrm{ha}^{-1}\right)$, Utley et al. (1971), obtiveram teores de FDA para o Coastcross 1 e Coastal de 328 e $344 \mathrm{~g} \mathrm{~kg}^{-1}$, respectivamente. Palhano (1990) observou aos 30 dias de crescimento que o FDN e o FDA foram de 716 e 379 $\mathrm{g} \mathrm{kg}^{-1}$, respectivamente, num estudo com Coastcross 1 adubado com $250 \mathrm{~kg}$ de $\mathrm{N}$ ha ${ }^{-1}$ e $250 \mathrm{~kg}$ de $\mathrm{K} \mathrm{ha}^{-1}$.

A verificação do comportamento das gramíneas forrageiras com o avanço da idade tem revelado grande influência da idade sobre o teor de fibra das mesmas. Nascimento e Pinheiro (1975) observaram com capim-jaraguá que o 
FDA aumentou significativamente $(\mathrm{P}<0,05)$ na matéria seca de 305 a $502 \mathrm{~g} \mathrm{~kg}^{-1}$ com intervalo entre cortes aumentando de 28 para 112 dias, respectivamente. $\mathrm{O}$ mesmo comportamento foi observado em Coastcross 1 com relação ao FDN e FDA (Palhano, 1990), que verificou incremento de 687 e 349 para 805 e 465 g $\mathrm{kg}^{-1}$ com o avanço da idade de 20 para 70 dias, respectivamente. No entanto, após 30 dias de crescimento, Daiub (1994) verificou variação mínima no teor de FDN e FDA com o tempo em Transvala (Digitaria decumbens).

Segundo Alvim et al. (1996), o teor de FDN diminuiu com o aumento do intervalo entre cortes do Coastcross 1 (variando de 600 até $730 \mathrm{~g} \mathrm{~kg}^{-1}$ ), e diminuiu de 710 para $610 \mathrm{~g} \mathrm{~kg}^{-1}$ quando a adubação nitrogenada aumentou de 0 para $750 \mathrm{~kg}$ de $\mathrm{N}^{-1} \mathrm{ano}^{-1}$. Ferrari Júnior et al. (1993) observaram que o FDN em Coastcross 1 foi maior $(\mathrm{P}<0,05)$ para áreas sem adubação $\left(766 \mathrm{~g} \mathrm{~kg}^{-1}\right)$ do que nas áreas onde foi feita adubação de reposição $\left(694 \mathrm{~g} \mathrm{~kg}^{-1}\right)$.

Reid et al. (1967a) não observaram correlação entre a adubação nitrogenada o teor de FDA em Ochardgrass. Por outro lado, Herrera e Ramos (1983), constataram que o teor de celulose em Coastcross 1 foi significativamente maior para o nível 0 do que para o nível $400 \mathrm{~kg}^{\mathrm{de}} \mathrm{N} \mathrm{ha}^{-1} \mathrm{ano}^{-1}$ na estação chuvosa, mas o mesmo não foi observado no teor de hemicelulose.

A adubação potássica também parece ter influência no teor de fibras de gramíneas. Em estudos com o Coastal, Eichhorn e Nelson (1988) observaram que a concentração tanto de FDN como de FDA decresceu $(\mathrm{P}<0,05)$ de 694 e 334 para 687 e $323 \mathrm{~g} \mathrm{~kg}^{-1}$, respectivamente, com a aplicação de 0 e $560 \mathrm{~kg} \mathrm{de} \mathrm{K} \mathrm{ha}^{-1}$. Também observou-se que o teor de potássio aumentou de 7 para $22,4 \mathrm{~g} \mathrm{~kg}^{-1}$, respectivamente com essa adubação e não foi observada variação significativa para a concentração de proteína bruta nessas condições. 


\subsubsection{Digestibilidade}

Freqüentemente utilizada como critério para seleção de espécies, a digestibilidade é um indicador da qualidade de uma forrageira, dando subsídios importantes para a produção animal (Minson e Mcleod, 1976; Herrera et al., 1985; Andriguetto et al., 1988).

Diversos trabalhos tem mostrado que a digestibilidade varia em função da espécie ou cultivar. Em Tifton, nos Estados Unidos da América, Hill et al. (1993) encontraram que a digestibilidade in vitro da matéria seca (DIVMS) foi significativamente mais elevada $(\mathrm{P}<0,05)$ para Tifton $85\left(596 \mathrm{~g} \mathrm{~kg}^{-1}\right)$ do que para

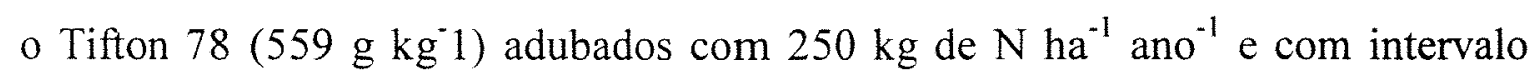
entre cortes de quatro semanas, num experimento com duração de três anos. Holt e Conrad (1986) observaram que o Tifton 68 foi mais digestivel $\left(661 \mathrm{~g} \mathrm{~kg}^{-1}\right)$ do que o Callie $\left(587 \mathrm{~g} \mathrm{~kg}^{-1}\right)$ e o Coastal $\left(547 \mathrm{~g} \mathrm{~kg}^{-1}\right)$ aos 28 dias de crescimento. O Tifton 85 apresentou, em média, maior DIVMO (554 $\left.\mathrm{g} \mathrm{kg}^{-1}\right)$ do que Florakirk (534 $\mathrm{g} \mathrm{kg}^{-1}$ ), segundo Pedreira (1995).

Trabalhando no Brasil com fenos de colonião, jaraguá e braquiária, Gomide et al. (1987) observaram que a DIVMS em média para esses capins foi de 510; 505 e $428 \mathrm{~g} \mathrm{~kg}^{-1}$, respectivamente. A DIVMS encontrada para capimgordura foi de $412 \mathrm{~g} \mathrm{~kg}^{-1}$, em média, para diferentes estádios de crescimento (Caielli et al., 1979); em feno de capim-de-rhodes (Chloris gayana) foi de $462 \mathrm{~g}$ $\mathrm{kg}^{-1}$ (Vieira et al., 1987) e em feno de braquiária foi de $429 \mathrm{~g} \mathrm{~kg}^{-1}$ (Castro et al., 1992).

Schank et al. (1977) obtiveram DIVMO de $606 \mathrm{~g} \mathrm{~kg}^{-1}$ em Coastcross 1. Palhano (1990) relatou que a DIVMS em Coastcross 1 foi de $690 \mathrm{~g} \mathrm{~kg}^{-1}$ e Beltran e Santa Cruz (1985) encontraram DIVMS de $581 \mathrm{~g} \mathrm{~kg}^{-1}$ para esse mesmo capim 
adubado com $100 \mathrm{~kg}$ de $\mathrm{N} \mathrm{ha}^{-1}$ ano $^{-1}$, em três cortes anuais. Por outro lado, com 60 dias de crescimento, Alcântara et al. (1981) obtiveram DIVMS de apenas $376 \mathrm{~g}$ $\mathrm{kg}^{-1}$ para o Coastcross 1 adubado com $200 \mathrm{~kg}$ de $\mathrm{N} \mathrm{ha}^{-1}$.

Em Coastcross 1, valores superiores do coeficiente de DIVMS foram observados por Duble et al. (1971), que obtiveram valor médio de $723 \mathrm{~g} \mathrm{~kg}^{-1}$, capim cortado a cada três semanas e adubado em média com $200 \mathrm{~kg}$ de $\mathrm{N} \mathrm{ha}^{-1}$ ano $^{-1}$. Nas mesmas condições de adubação nitrogenada e periodo de crescimento, Gutierrez et al. (1980), obtiveram coeficiente de DIVMS de $645 \mathrm{~g} \mathrm{~kg}^{-1} \mathrm{em}$ Coastcross 1.

$\mathrm{Na}$ Nigéria, Olubajo et al. (1974) observaram grande variação na digestibilidade de alguns capins, sendo que os valores médios encontrados para a DIVMS foram de $620,580,550$ e $470 \mathrm{~g} \mathrm{~kg}^{-1}$ para o Pennisetum purpureum, Panicum maximum, Cynodon Ib8 e Cynodon plectostachyum, respectivamente, com seis semanas de crescimento.

Utley et al. (1971) observaram que digestibilidade in vivo aparente do Coastcross $1\left(654 \mathrm{~g} \mathrm{~kg}^{-1}\right)$ foi maior $(\mathrm{P}<0,01)$ do que a do Coastal $\left(620 \mathrm{~g} \mathrm{~kg}^{-1}\right)$ com quatro semanas de crescimento. O Coastcross 1 também foi mais digestível do que o Pensacola, o Alicia e o Coastal, tendo em média $50 \mathrm{~g} \mathrm{~kg}^{-1}$ a mais de digestibilidade do que o segundo mais digestível, o Pensacola (Brown et al., 1976).

Num estudo com capins-bermuda de alta qualidade, entre eles o Coastcross 1, e capins-bermuda de baixa qualidade, Hanna et al. (1976) não observaram diferenças histológicas nem anatômicas entre essas plantas, mas relataram que as plantas de alta qualidade pareciam ter maior DIVMS devido à maior quantidade de constituintes solúveis e maior digestibilidade da parede celular. 
Segundo Van Soest (1994) os fatores ambientais que influenciam na composição da planta forrageira são a temperatura, comprimento do dia, latitude, disponibilidade de água, desfoliações, doenças, solo e adubação. A interação desses fatores aliados à genética e maturidade das forrageiras alteram a digestibilidade.

Maraschin e Mott (1989), em estudos com associações de algumas leguminosas com o Coastcross 1 , observaram que a DIVMO (digestibilidade in vitro da matéria orgânica) diminuiu linearmente $(\mathrm{P}<0,05)$ com o aumento do resíduo deixado no pasto, influenciado pela pressão de pastejo e pelos dias de descanso da pastagem. Por outro lado, Garcia Soldevilla et al. (1981) não observaram influência da lotação da DIVMS de Coastcross 1 .

A temperatura é freqüentemente citada na literatura como um dos fatores de maior influência na digestibilidade das gramíneas. Nesse sentido, Wilson et al. (1991), em estudos com três espécies do tipo C4, entre elas um Cynodon dactylon, e duas do tipo $\mathrm{C} 3$ observaram decréscimo significativo na DIVMO das folhas e das hastes com a elevação da temperatura e concluíram que ela está também associada ao aumento do teor de lignina nessas plantas. Segundo Duble et al. (1971) o teor de sílica e de lignina influenciam na digestibilidade do Coastcross 1.

Existe correlação entre o teor de fibra e digestibilidade de uma gramínea. Nascimento e Pinheiro (1975) relataram que para cada $10 \mathrm{~g} \mathrm{~kg}^{-1}$ de aumento no teor de FDA houve redução nos coeficientes de DIVMS de $15 \mathrm{~g} \mathrm{~kg}^{-1}$ no capimjaraguá. Os autores concluíram ainda que a lignina influiu mais do que a fibra no decréscimo dos teores de digestibilidade.

Forde et al. (1976), em estudos com 20 espécies de gramíneas temperadas e tropicais, observaram que a DIVMS foi usualmente mais elevada nas gramíneas temperadas do que nas tropicais. Também observaram que a DIVMS não foi 
influenciada significativamente pela hora do dia em que foi realizado o corte e nem pela irrigação. Por outro lado, Dias Filho et al. (1991) observaram que a DIVMO do Tobiatã foi maior quanto mais intenso foi o estresse hídrico ao qual o capim foi submetido.

Segundo Monson e Burton (1982), há um amplo decréscimo na DIVMS de capins do gênero Cynodon com a idade, especialmente entre quatro e oito semanas de crescimento. Outros autores também relataram decréscimo na digestibilidade com o avanço da idade em capins como orchardgrass (Reid et al.,1967a); Festuca (Reid et al., 1967b); em capim-jaraguá (Nascimento e Pinheiro, 1975); capim-colonião (Vieira et al., 1980); Coastal, Callie, capimbermuda S-16, Tifton 68 e capim-bermuda S-83 (Holt e Conrad, 1986); Coastal, Festuca e Pennisetum (Silva et al., 1987); Coastcross 1 (Gutierrez et al., 1980; Herrera et al., 1985; Palhano, 1990); capim-bermuda seleção RS1 (Belesky et al., 1991); Digitária decumbens (Daiub, 1994). Hanna et al. (1976) concluíram que a redução na digestibilidade com o incremento da idade em capim-bermuda ocorre principalmente devido à alterações nas hastes desses capins.

Segundo Van Soest (1994), geralmente a fertilização nitrogenada tende a reduzir suavemente a digestibilidade das forrageiras. Tal informação discorda de Waite (1970), que acredita que o efeito usual da aplicação de fertilizantes nitrogenados constitui num aumento no crescimento da gramínea, aumento no teor de nitrogênio nos tecidos, decréscimo no teor de fibra bruta e aumento na digestibilidade. Blaser (1964) fez uma revisão sobre o assunto e concluiu que a fertilização nitrogenada promove um aumento na digestibilidade. Sobre os demais nutrientes, no entanto, poucos estudos tem sido conduzidos com relação a qualidade de forragem (Van Soest, 1994). 
A digestibilidade in vivo da matéria seca de feno de timothy (Phleum pratense) decresceu de 645 para $614 \mathrm{~g} \mathrm{~kg}^{-1}$ para adubação de 0 e $225 \mathrm{~kg}_{\text {de N ha }}{ }^{-1}$, respectivamente (Woelfel e Poulton, 1960). Tal informação discorda de Waite (1970) que relatou mínima alteração na porcentagem da digestibilidade in vitro de capim-azevém (Lolium perenne) com a adubação nitrogenada mas incrementou em $48 \%$ a produção de matéria orgânica digestível.

Monson e Burton (1982) observaram que o aumento na adubação nitrogenada de 336 para $672 \mathrm{~kg}$ de $\mathrm{N}_{\text {ha }}{ }^{-1}$ em média aumentou significativamente $(\mathrm{P}<0,05)$ a DIVMS de cinco espécies e híbridos de Cynodon. Nesse estudo, a mais alta DIVMS foi de $686 \mathrm{~g} \mathrm{~kg}^{-1}$ para o Tifton 68 , sendo que o Coastcross 1 apresentou DIVMS de $647 \mathrm{~g} \mathrm{~kg}^{-1}$, na dose mais alta de nitrogênio e com quatro semanas de crescimento. Ferrari Júnior et al. (1993) também observaram aumento $(\mathrm{P}<0,05)$ na DIVMS de Coastcross 1 com 42 dias de idade em áreas com a adubação de reposição nitrogenada e potássica $\left(654 \mathrm{~g} \mathrm{~kg}^{-1}\right)$, comparado às áreas sem essa adubação (592 $\left.\mathrm{g} \mathrm{kg}^{-1}\right)$.

Herrera et al. (1985) obtiveram incremento da DIVMS do Coastcross com adubação nitrogenada de até $400 \mathrm{~kg}$ de $\mathrm{N} \mathrm{ha}^{-1} \mathrm{ano}^{-1}$, sendo que o valor mais alto foi de $601 \mathrm{~g} \mathrm{~kg}^{-1}$, na estação chuvosa e na primeira semana de crescimento. Em estudos com a mesma gramínea, Coto et al. (1990) não observaram diferenças significativas entre os teores de DIVMO de 581; 578 e $575 \mathrm{~g} \mathrm{~kg}^{-1}$ para as adubações com 0,200 e $400 \mathrm{~kg}$ de $\mathrm{N} \mathrm{ha}^{-1}$ ano $^{-1}$, respectivamente. Comportamento semelhante foi obtido por Cáceres et al. (1989), onde não observaram diferença significativa na digestibilidade in vivo da matéria orgânica com a adubação nitrogenada de até $400 \mathrm{~kg}$ de $\mathrm{N} \mathrm{ha}^{-1}$ em Coastcross 1 . Na Nova Zelândia, um estudo realizado com cinco espécies de gramíneas, entre elas o Coastcross 1 , 
demonstrou que a digestibilidade in vivo prevista da matéria seca foi, em média, pouco afetada pela adubação nitrogenada (Rumball, 1991).

Caro-Costas et al. (1976) não observaram variação na DIVMS de capimestrela adubado com N e K na proporção de 270 e 150 até 670 e $370 \mathrm{~kg} \mathrm{ha}^{-1}$, respectivamente. A digestibilidade da matéria seca aumentou de 533 para $550 \mathrm{~g}$ $\mathrm{kg}^{-1}$ com o aumento na adubação potássica de 0 até $370 \mathrm{~kg}$ de $\mathrm{K} \mathrm{ha}^{-1}$ em Coastal cortado quatro vezes ao ano, porém esse aumento não foi significativo a $5 \%$ de probabilidade (Eichhorn e Nelson, 1988). 


\section{MATERIAL E MÉTODOS}

\subsection{Gramíneas estudadas}

Os capins estudados foram o Coastcross 1 [Cynodon dactylon (L.) Pers. cv. Coastcross 1] e o Tifton 85 [Cynodon spp.(reg. $\mathrm{n}^{0}$ CV-20, PI 562699)]. Segundo Burton (1972), o Coastcross 1 possui estolões que se desenvolvem rapidamente e, apesar de ser um capim-bermuda, falha no desenvolvimento de rizomas. É altamente resistente à doenças foliares e à "penetração" de nematóides. O Coastcross 1 possui pêlos aderidos à lígula medindo 3 a $4 \mathrm{~mm}$ de comprimento e espaçados a cada 3 a $4 \mathrm{~mm}$, em ambos os lados da lâmina.

O Tifton 85 é estéril e mais alto, com hastes maiores e folhas mais largas do que outros capim-bermuda, além de folhas com coloração verde mais escuro. Também possui rizomas grandes e com rápido crescimento (Burton et al., 1993).

\subsection{Local e período}

O experimento foi desenvolvido em casa-de-vegetação no Departamento de Química da Escola Superior de Agricultura "Luiz de Queiroz" (ESALQ/USP), em Piracicaba, SP.

O preparo do solo e plantio das mudas iniciaram-se em junho de 1995. A fase experimental de cultivo das plantas teve início em novembro de 1995 e foi concluída em fevereiro de 1996, portanto na época quente do ano. 


\subsection{Preparo do substrato}

Foi utilizada como substrato terra proveniente de um perfil de um Latossolo Vermelho-Amarelo ácrico (Haplustox), do cerrado do Estado de Goiás. A terra foi coletada, secada e peneirada. Amostra dessa terra foi analisada quimicamente antes da implantação do experimento e os resultados podem ser observados na Tabela 1.

Tabela 1. Resultados da análise química do solo em amostra retirada antes da implantação do experimento.

\begin{tabular}{cccccccccc}
\hline $\begin{array}{c}\mathrm{P} \text { (resina) } \\
\mathrm{mg} \mathrm{dm}^{-3}\end{array}$ & $\begin{array}{c}\mathrm{M} . \mathrm{O} \\
\mathrm{dag} \mathrm{kg}^{-1}\end{array}$ & $\begin{array}{c}\mathrm{pH} \\
\mathrm{CaCl}_{2}\end{array}$ & $\mathrm{~K}$ & $\mathrm{Ca}$ & $\mathrm{Mg}$ & $\mathrm{H}+\mathrm{Al}$ & $\mathrm{S}$ & $\mathrm{T}$ & $\mathrm{V}$ \\
\hdashline 1,6 & 3,27 & 4,70 & 0,13 & 0,13 & 0,11 & 6,44 & 0,40 & 6,8 & 5,5 \\
\hline
\end{tabular}

A necessidade de calagem foi calculada através do método da saturação por bases visando atingir a saturação por bases $\left(\mathrm{V}_{2}\right)$ de $60 \%$, de acordo Werner (1986). Foi aplicado o equivalente a 3,7 $\mathrm{Mg} \mathrm{ha}^{-1}$, utilizando-se $\mathrm{CaO}$ e $\mathrm{MgO}$ puros para análise como corretivos, numa proporção $\mathrm{CaCO}_{3}: \mathrm{MgCO}_{3}$ de 2:1.

O corretivo foi pesado e adicionado aos sacos plásticos contendo $3,9 \mathrm{~kg}$ de terra. Esse material foi então agitado manualmente dentro dos sacos plásticos por quatro minutos para homogeneização e foi então colocado em vasos plásticos. Em seguida foram adicionados $1050 \mathrm{ml}$ de água destilada por vaso, para que o solo atingisse a capacidade de campo. Os vasos tiveram seus pesos anotados e água evaporada foi reposta diariamente de acordo com a variação do peso dos mesmos, pelo periodo de incubação de 61 dias, até o plantio das mudas. 


\subsection{Preparo das mudas e plantio}

As mudas foram plantadas em recipientes de cimento amianto contendo areia fina adubada com superfosfato simples com o objetivo de multiplicar a quantidade de mudas disponíveis para a implantação do experimento. O plantio foi realizado quatro (Tifton 85) e dois (Coastcross 1) meses antes do início do experimento. Nesse período as plantas foram irrigadas diariamente e também foi aplicada uma solução nutritiva baseada na solução de Sarruge (1975) contendo micronutrientes $(\mathrm{B}, \mathrm{Cl}, \mathrm{Cu}, \mathrm{Fe}, \mathrm{Mn}, \mathrm{Mo}$ e $\mathrm{Zn}$ ), nitrato de cálcio, fosfato de magnésio e sulfato de magnésio, porém nenhuma forma de potássio foi utilizada nessa época.

Antes do início do experimento foi realizado um teste pré-plantio em um vaso contendo a terra a ser utilizada no trabalho com alguns tipos de mudas. Todas brotaram, porém as mudas com raízes tiveram uma brotação mais rápida e intensa e por isso foi o tipo escolhido de muda para o experimento.

As mudas foram destacadas manualmente das plantas de forma que as raizes e folhas fossem mantidas e tivessem tamanhos regulares. Em seguida, as mudas foram lavadas em água corrente e depois em água destilada e plantadas nos vasos. Foram utilizadas oito mudas por vaso, e realizaram-se posteriormente desbastes até atingir cinco plantas em cada vaso.

\subsection{Delineamento experimental e análise estatística}

O delineamento experimental foi o de blocos ao acaso com quatro repetições. Foram estudados dois cultivares, três doses de nitrogênio e três doses de potássio, em um fatorial completo $(2 \times 3 \times 3)$. Os resultados foram avaliados 
através do programa SAS (Statistical Analysis System) na forma de regressão linear ou quadrática e do teste de Tukey. Todos as regressões apresentadas foram testadas (teste F) para a significância estatística mínima de 5\% de probabilidade.

\subsection{Adubação básica e doses de nitrogênio e de potássio}

Após o período de incubação do solo foi realizada outra amostragem para fins de análise do solo (Tabela 2). Com base nos resultados desta análise do solo foi executada uma adubação geral em todos os vasos, a qual foi aplicada no mesmo dia do plantio das mudas. Essa adubação conteve o equivalente a: $60 \mathrm{~kg}$ de $\mathrm{Pha}{ }^{-1}$ como $\mathrm{Ca}\left(\mathrm{H}_{2} \mathrm{PO}_{4}\right)_{2} \cdot \mathrm{H}_{2} \mathrm{O}$ e $60 \mathrm{~kg}$ de $\mathrm{P} \mathrm{ha}^{-1}$ como $\mathrm{NaH}_{2} \mathrm{PO}_{4} \cdot \mathrm{H}_{2} \mathrm{O} ; 60 \mathrm{~kg}$ de $\mathrm{S} \mathrm{ha}^{-1}$ como $\mathrm{MgSO}_{4} \cdot 7 \mathrm{H}_{2} \mathrm{O} ; 3 \mathrm{~kg}$ de $\mathrm{Zn} \mathrm{ha}^{-1}$ como $\mathrm{ZnSO}_{4} .7 \mathrm{H}_{2} \mathrm{O} ; 2 \mathrm{~kg}$ de Cu ha ${ }^{-1}$ como $\mathrm{CuSO}_{4} .5 \mathrm{H}_{2} \mathrm{O} ; 0,5 \mathrm{~kg}$ de B ha ${ }^{-1}$ como $\mathrm{H}_{3} \mathrm{BO}_{3}$ e $0,25 \mathrm{~kg}$ de $\mathrm{Mo} \mathrm{ha}^{-1}$ como $\left(\mathrm{NH}_{4}\right)_{6} \mathrm{Mo}_{7} \mathrm{O}_{24} \cdot 4 \mathrm{H}_{2} \mathrm{O}$.

Tabela 2. Resultados da análise química em amostra solo após o período de incubação.

\begin{tabular}{cccccccccc}
\hline $\begin{array}{c}\text { P(resina) } \\
\mathrm{mg} \mathrm{dm}^{-3}\end{array}$ & $\begin{array}{c}\text { M.O. } \\
\text { dag kg}\end{array}$ & $\begin{array}{c}\mathrm{pH} \\
\mathrm{CaCl}_{2}\end{array}$ & $\mathrm{~K}$ & $\mathrm{Ca}$ & $\mathrm{Mg}$ & $\mathrm{H}+\mathrm{Al}$ & $\mathrm{S}$ & $\mathrm{T}$ & $\mathrm{V}$ \\
& 3,20 & 5,30 & 0,12 & 2,05 & 1,55 & 3,91 & 3,72 & 7,63 & 48,7 \\
\hline
\end{tabular}

O nitrogênio e o potássio foram aplicados quatro dias após o corte de uniformização contendo o equivalente em nitrogênio a $N_{20}=20, N_{100}=100$ e $\mathrm{N}_{180}=180 \mathrm{~kg}$ de $\mathrm{N} \mathrm{ha}^{-1}$ corte $^{-1}$ e o equivalente em potássio a $\mathrm{K}_{15}=15, \mathrm{~K}_{75}=75 \mathrm{e}$

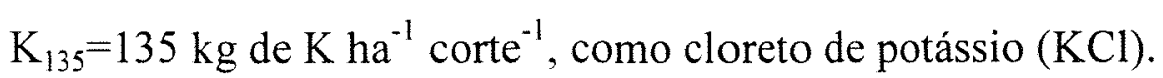


Para a adubação nitrogenada foram utilizadas duas fontes de nitrogênio com equivalentes em carbonato de cálcio negativos e positivos visando não alterar o potencial hidrogeniônico do solo, especialmente nos níveis mais elevados de nitrogênio. As fontes utilizadas foram a uréia e o nitrato de cálcio que, segundo Malavolta (1981), possuem equivalentes a $-1,80 \mathrm{e}+1,35 \mathrm{~kg}$ de $\mathrm{CaCO}_{3} \mathrm{~kg} \mathrm{~kg}^{-1} \mathrm{de}$ $\mathrm{N}$, respectivamente. Foi aplicado $75 \%$ do nitrogênio na forma de uréia e $25 \%$ na forma de nitrato de cálcio (Tabela 3).

Tabela 3. Quantidade de nitrogênio $(\mathrm{N})$ aplicado na forma de uréia e nitrato de cálcio e quantidade de cálcio veiculada pelo nitrato de cálcio em cada tratamento em equivalente a $\mathrm{kg} \mathrm{ha}^{-1}$.

\begin{tabular}{cccc}
\hline $\begin{array}{c}\mathrm{N} \\
\mathrm{kg} \mathrm{ha}\end{array}{ }^{-1}$ & $\left.\mathrm{NH}_{2}\right)_{2} \mathrm{CO}$ & $\begin{array}{c}\mathrm{Ca}\left(\mathrm{NO}_{3}\right)_{2} .4 \mathrm{H}_{2} \mathrm{O} \\
\left.\mathrm{N}(\mathrm{kg} \mathrm{ha})^{-1}\right)\end{array}$ & $\begin{array}{c}\text { Ca veiculado } \\
\left(\mathrm{kg} \mathrm{ha}^{-1}\right)\end{array}$ \\
\hline 20 & 8,6 & 11,4 & 16,3 \\
100 & 42,9 & 57,1 & 81,7 \\
180 & 77,1 & 102,9 & 147,1 \\
\hline
\end{tabular}

Nos níveis mais elevados de nitrogênio foi aplicado mais nitrato de cálcio, e portanto forneceu mais cálcio para esses vasos (Tabela 3). Com o objetivo de corrigir a diferença entre quantidades de cálcio aplicadas foram utilizados 130,8 e $65,4 \mathrm{~kg} \mathrm{ha}^{-1}$ de cálcio (como $\mathrm{CaCl}_{2}$ ) nos vasos das doses 20 e $100 \mathrm{~kg}$ de $\mathrm{N} \mathrm{ha}^{-1}$ respectivamente.

\subsection{Coleta e pesagem do material}

Oito dias após o plantio realizou-se um corte de uniformização a $5 \mathrm{~cm}$ de altura do solo em todas as plantas. Além do corte de uniformização foram 
realizados três cortes na parte aérea das plantas a uma altura $1,5 \mathrm{~cm}$ do nivel do solo. O primeiro corte foi executado aos 44 dias da implantação do experimento, e o segundo e o terceiro cortes ocorreram após 32 e 26 dias de crescimento, respectivamente, baseados nas recomendações para o corte a cada 30 a 40 dias em Coastcross 1 (Palhano, 1990) ou 28 a 35 dias para o mesmo capim (Alvim et al., 1996).

Após cada corte foram separadas as lâminas das hastes + bainhas e todo o material foi colocado em estufa a $65^{\circ} \mathrm{C}$ até atingir peso constante. As lâminas e as hastes + bainhas secas foram pesadas separadamente com o objetivo de verificar a relação entre hastes (peso da haste mais bainha das folhas) e as lâminas dos capins.

\subsection{Determinação do teor de nutrientes, fibras e digestibilidade in vitro da matéria seca.}

A determinação dos teores de nutrientes no tecido das plantas foi realizada no Laboratório de Nutrição Mineral de Plantas da ESALQ/USP, seguindo os métodos descritos por Sarruge e Haag (1974).

As análises bromatológicas foram executadas no Laboratório de Bromatologia do Departamento de Zootecnia da ESALQ/USP. Para realização dessas análises foram unidas as amostras dos blocos 1 e 2 (uma amostra), e dos blocos 3 e 4 (outra amostra) devido à escassez de material. Parte das amostras foram novamente secadas em estufa a $100^{\circ} \mathrm{C}$.

A digestibilidade in vitro (DIVMS) foi determinada segundo método de Tilley e Terry (1963), modificado por Tinimit (1974), com a utilização de sulfito de sódio $\left(\mathrm{Na}_{2} \mathrm{SO}_{3}\right)$ juntamente com o detergente neutro. Para fibra em detergente 
neutro (FDN) e fibra detergente ácido (FDA) foi utilizado o método de Goering e Van Soest (1970). 


\section{RESULTADOS E DISCUSSÃO}

\subsection{Produção de matéria seca da parte aérea e das raízes}

Para a produção de matéria seca da parte aérea, não houve diferença significativa $(\mathrm{P}>0,05)$ entre os capins estudados. O Tifton 85 somente foi superior ao Coastcross 1 para a dose de $180 \mathrm{~kg}$ de $\mathrm{N}$ e $15 \mathrm{~kg}$ de $\mathrm{K} \mathrm{ha}^{-1}$ no segundo crescimento (Tabela 4). Esses resultados demonstram que esses capins são similares no que se refere à produção de matéria seca da parte aérea, nas condições desse experimento. Essa produção variou, no entanto, com a aplicação de nitrogênio no primeiro crescimento e teve efeito significativo para a interação nitrogênio $\mathrm{x}$ potássio $\mathrm{x}$ cultivares no segundo crescimento e para a interação nitrogênio $x$ potássio no terceiro crescimento.

Tabela 4. Produção de matéria seca da parte aérea $\left(\mathrm{g} \mathrm{vaso}^{-1}\right)$ dos capins Tifton 85 e Coastcross 1, no segundo crescimento, em função das doses de nitrogênio e de potássio.

\begin{tabular}{|c|c|c|c|}
\hline \multirow{3}{*}{ Forrageiras } & \multicolumn{3}{|c|}{ Doses $\left(\mathrm{kg} \mathrm{ha}^{-1}\right)$} \\
\hline & $N=20$ & $\mathrm{~N}=100$ & $\mathrm{~N}=180$ \\
\hline & \multicolumn{3}{|c|}{$\mathrm{K}=15$} \\
\hline Tifton 85 & $11,9 \mathrm{a}$ & $\overline{15,4 a}$ & $\overline{17,9 a}$ \\
\hline \multirow[t]{2}{*}{ Coastcross 1} & $13,2 \mathrm{a}$ & $14,9 \mathrm{a}$ & $16,1 \mathrm{~b}$ \\
\hline & \multicolumn{3}{|c|}{$\mathrm{K}=75$} \\
\hline Tifton 85 & $13,1 \mathrm{a}$ & $17,8 \mathrm{a}$ & $18,3 \mathrm{a}$ \\
\hline \multirow[t]{2}{*}{ Coastcross 1} & $13,4 \mathrm{a}$ & $13,2 \mathrm{a}$ & $20,8 \mathrm{a}$ \\
\hline & \multicolumn{3}{|c|}{$\mathrm{K}=135$} \\
\hline Tifton 85 & $13,9 \mathrm{a}$ & $19,6 \mathrm{a}$ & $20,7 \mathrm{a}$ \\
\hline Coastcross 1 & $14,8 \mathrm{a}$ & $19,7 \mathrm{a}$ & $20,9 a$ \\
\hline
\end{tabular}




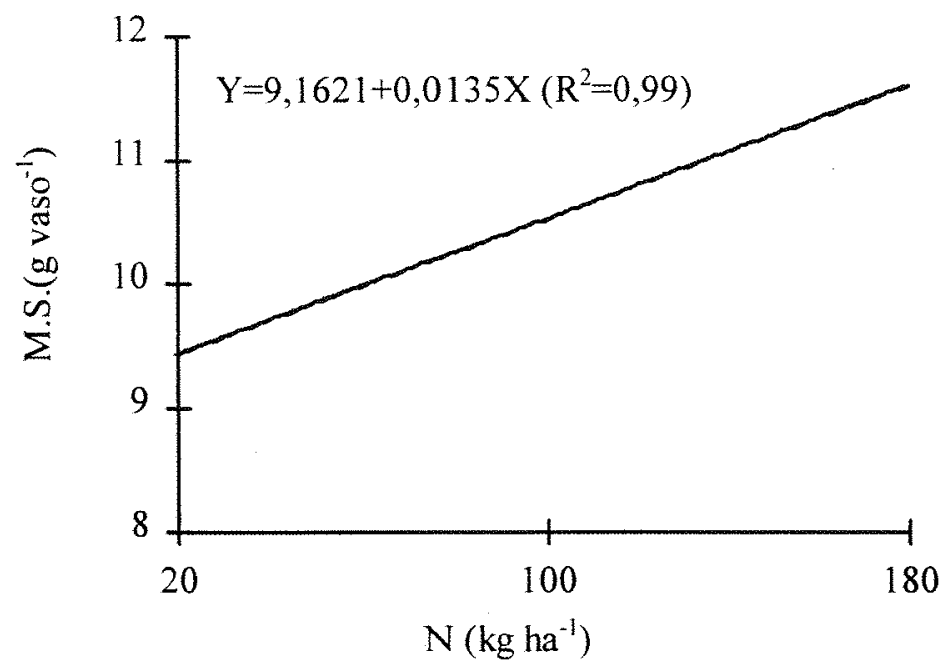

Figura 1. Média da produção de matéria seca da parte aérea dos capins Tifton 85 e Coastcross 1, no primeiro crescimento, em função das doses de nitrogênio.

No primeiro crescimento a produção de matéria seca aumentou linearmente $(\mathrm{P}<0,01)$ com a adubação nitrogenada (Figura 1), mas não teve variação significativa em função das doses de potássio. Fato semelhante ocorreu no segundo crescimento na dose mais baixa de nitrogênio, como pode ser observado na Figura 2. É também possível observar nessa figura que a utilização da dose 15 $\mathrm{kg}$ de $\mathrm{K} \mathrm{ha}^{-1}$ limitou mais o desenvolvimento do Coastcross 1 do que do Tifton 85, revelando que, nessas condições, o Coastcross 1 mostrou-se mais exigente a esse nutriente. 


\section{TIFTON 85}
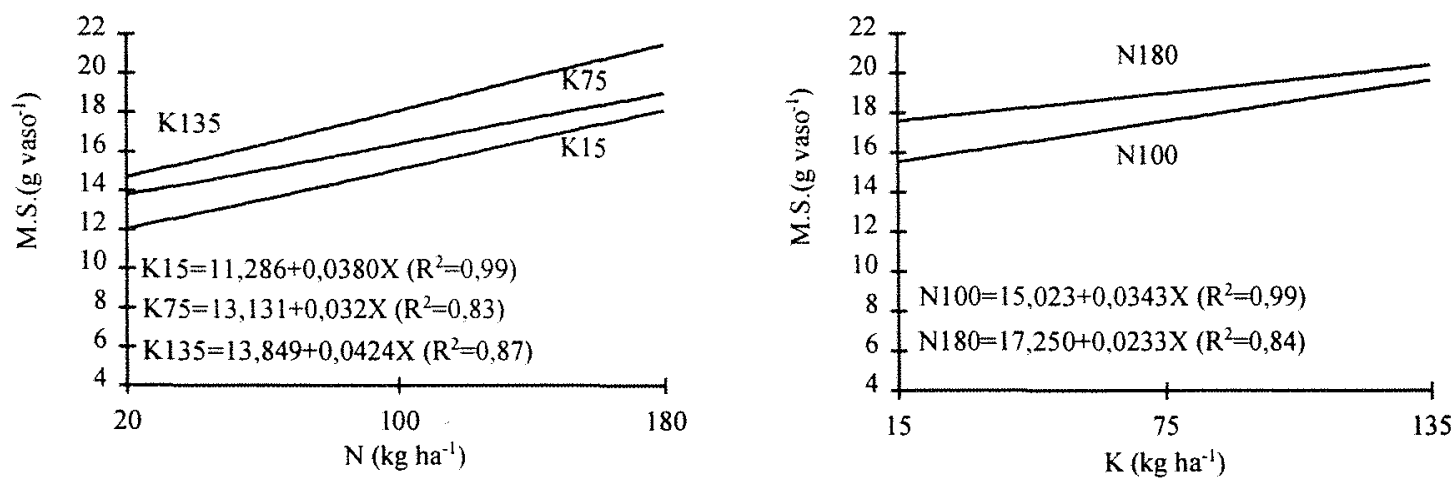

COASTCROSS 1
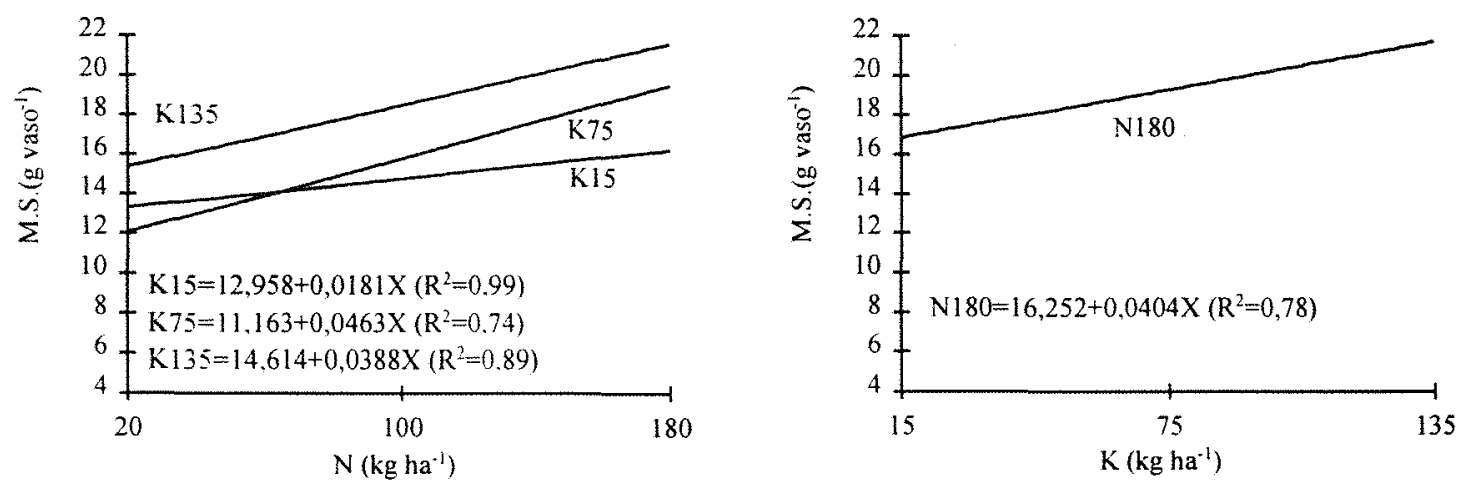

Figura 2. Produção de matéria seca da parte aérea dos capins Tifton 85 e Coastcross 1, no segundo crescimento, em função das doses de nitrogênio e de potássio.

Tanto no segundo como no terceiro crescimento a produção de matéria seca da parte aérea foi maior quanto mais elevadas as doses de nitrogênio e de potássio. No entanto, no terceiro crescimento, a variação na produção de matéria seca com os níveis de nitrogênio foi muito mais acentuada do que com os de potássio (Figura 3), concordando com Alvim et al. (1996), que afirmaram que o nitrogênio foi o nutriente de maior influência no aumento da produção de matéria seca em Coastcross 1. 

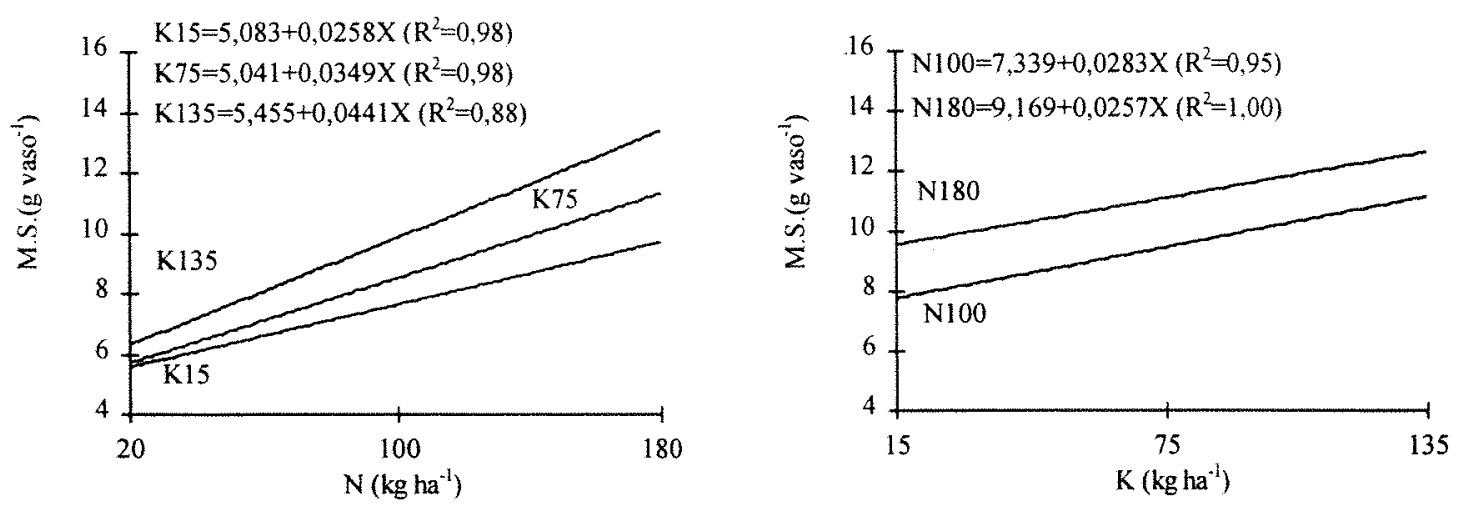

Figura 3. Média da produção de matéria seca da parte aérea dos capins Tifton $85 \mathrm{e}$ Coastcross 1, no terceiro crescimento, em função das doses de nitrogênio e de potássio.

O Tifton 85 e o Coastcross 1 mostraram-se bastante responsivos a adubação. $\mathrm{O}$ aumento na produção de matéria seca desses capins em função das doses de nitrogênio dentro da mais elevada dose de potássio, foi em média de $43 \mathrm{e}$ $113 \%$ no segundo e terceiro crescimentos, respectivamente. Esses valores foram superiores aos encontrados por Monson e Burton (1982), os quais relataram que houve um aumento médio de $18 \%$ na produção de matéria seca quando a dose de

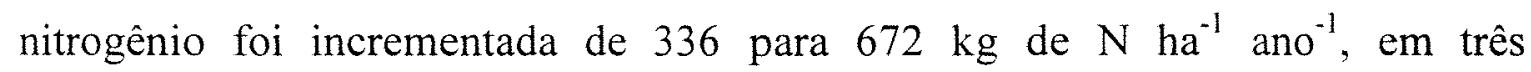

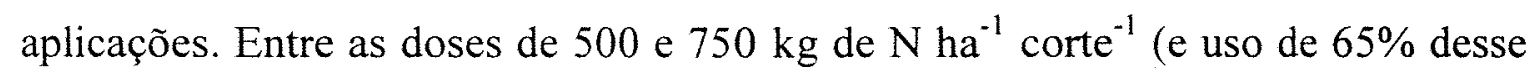
valor em K), Alvim et al. (1996) não obtiveram diferença significativa $(\mathrm{P}>0,05)$ para produção de matéria seca no Coastcross 1 .

Para a dose de nitrogênio de $180 \mathrm{~kg}$ de $\mathrm{N} \mathrm{ha}^{-1}$, o aumento da produção de

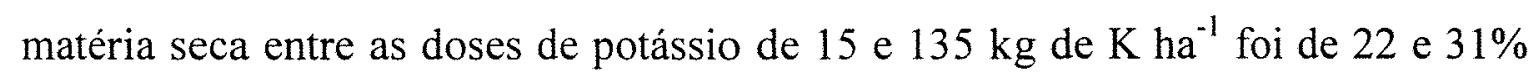
no segundo e terceiro cortes, respectivamente, sendo inferior ao observado por Adams et al. (1967) que obtiveram aumento de $66 \%$ na produção de matéria seca 


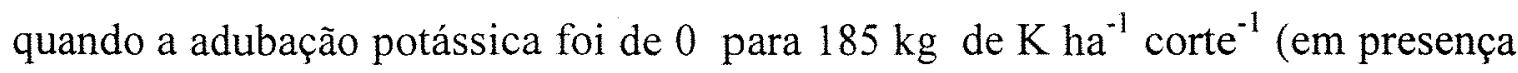
de $224 \mathrm{~kg}$ de $\mathrm{N} \mathrm{ha}^{-1}$ corte $^{-1}$ ).

No presente estudo, nas doses mais elevadas de nitrogênio e de potássio foi empregada uma relação $\mathrm{N}: \mathrm{K}$ de $1,3: 1$, a qual foi a mesma recomendada por Cripps et al. (1989); mas inferior a sugestão de Freitas e Jorge (1982), Hernández e Cárdenas (1987), Pacheco et al. (1987) e Alvim et al. (1996) que foi de 3,6:1, $3,6: 1,2,4: 1$ e 1,5:1, respectivamente e superior à recomendação de $1: 1$ de Andrade et al. (1991) e Ferrari Júnior et al. (1993). A acentuada resposta do Tifton 85 e do Coastcross 1 em função da adubação potássica nas condições desse estudo sugere que o emprego de menor relação $\mathrm{N}: \mathrm{K}$ poderia ser estudada para esses capins.

A produção de matéria seca das raízes foi semelhante em ambos capins, porém foi superior no Tifton $85(\mathrm{P}<0,05)$ quando foram utilizadas as doses $100 \mathrm{~kg}$ de $\mathrm{N}$ e $135 \mathrm{~kg}_{\text {de }} \mathrm{K} \mathrm{ha}^{-1}$ e as doses $180 \mathrm{~kg}$ de $\mathrm{Ne} 15 \mathrm{~kg}$ de $\mathrm{K} \mathrm{ha}^{-1}$, como pode ser observado na Tabela 5 .

Semelhante ao comportamento observado da parte aérea dos capins, a produção de matéria seca das raízes aumentou linearmente com as doses de potássio e nitrogênio (Figura 4). Segundo Favoretto e Monteiro (1992), o nitrogênio e o potássio foram os nutrientes que mais limitaram a produção de matéria seca das raizes de aveia. Abreu (1994) verificou que a produção de matéria seca de raízes aumentou significativamente $(\mathrm{P}<0,01)$ com as doses de nitrato utilizadas em solução nutritiva no capim-gordura, na braquiária Marandú e no Tanzânia 1. 


\section{TIFTON 85}
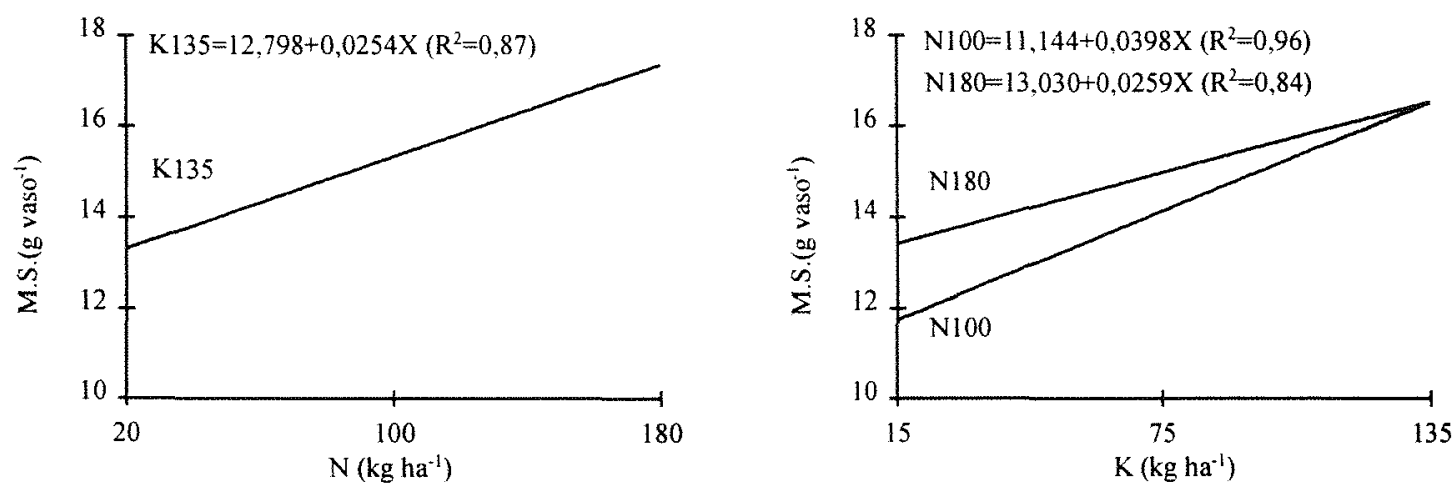

\section{COASTCROSS 1}
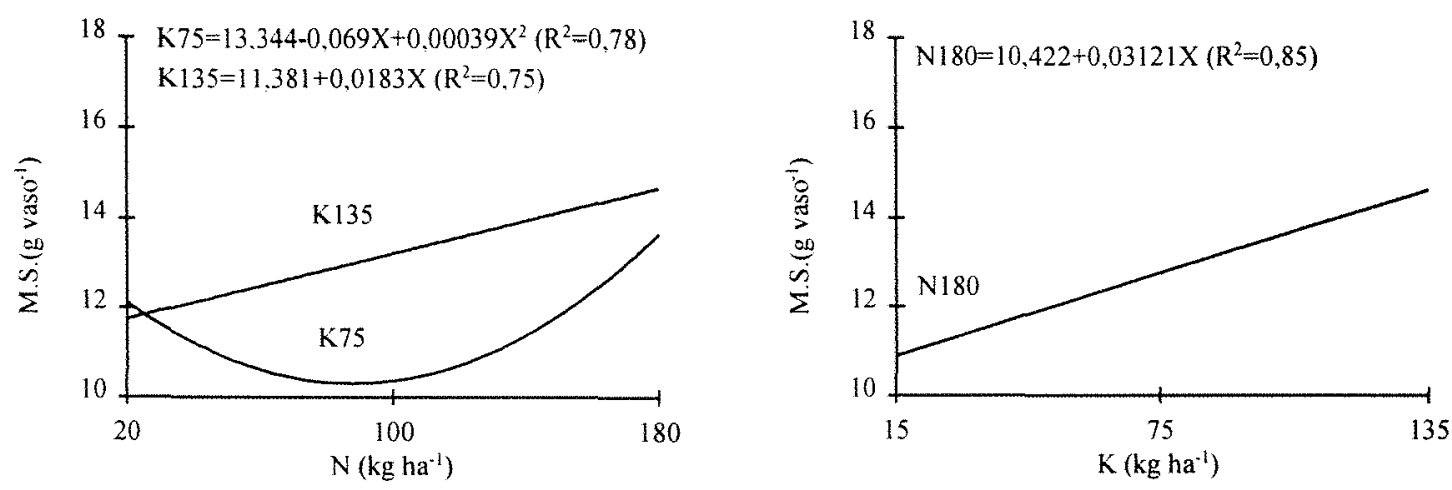

Figura 4. Produção de matéria seca das raizes de Tifton 85 e Coastcross 1 , em função das doses de nitrogênio e de potássio. 
Tabela 5. Produção de matéria seca das raízes $\left(\mathrm{g}\right.$ vaso $\left.^{-1}\right)$ dos capins Tifton 85 e Coastcross 1, no segundo crescimento, em função das doses de nitrogênio e de potássio.

\begin{tabular}{l|c|c|c}
\hline \multirow{2}{*}{ Forrageiras } & \multicolumn{3}{|c}{ Doses $\left(\mathrm{kg} \mathrm{ha}^{-1}\right)$} \\
\cline { 2 - 4 } & $\mathrm{N}=20$ & $\mathrm{~N}=100$ & $\mathrm{~N}=180$ \\
\cline { 2 - 4 } & $11,89 \mathrm{a}$ & $\mathrm{K}=15$ & $11,46 \mathrm{a}$ \\
Tifton 85 & $10,41 \mathrm{a}$ & $10,78 \mathrm{a}$ & $10,44 \mathrm{~b}$ \\
\hline Coastcross 1 & $11,61 \mathrm{a}$ & $\mathrm{K}=75$ \\
\hline Tifton 85 & $12,12 \mathrm{a}$ & $14,68 \mathrm{a}$ & $14,20 \mathrm{a}$ \\
Coastcross 1 & \multicolumn{3}{|c}{$10,36 \mathrm{a}$} \\
\hline \multicolumn{3}{|c}{$\mathrm{K}=135$} \\
\hline Tifton 85 & $12,85 \mathrm{a}$ & $16,24 \mathrm{a}$ & $16,92 \mathrm{a}$ \\
Coastcross 1 & $11,26 \mathrm{~b}$ & $14,18 \mathrm{~b}$ & $14,19 \mathrm{a}$ \\
\hline Médias seguidas de letras diferentes na mesma subcoluna diferem \\
estatisticamente a 5\% de probabilidade pelo teste de Tukey.
\end{tabular}

\subsection{Relação haste:lâmina nos capins}

No primeiro crescimento houve aumento linear $(\mathrm{P}<0,05)$ da relação haste:lâmina com a adubação potássica apenas para o Tifton 85 , a qual variou entre os limites 1,03 e de 1,15 (Figura 5) enquanto no segundo crescimento esse aumento ocorreu nos dois cultivares (Figura 6). A relação haste:lâmina no segundo crescimento atingiu 1,43 em Coastcross 1 e 1,14 em Tifton 85 para a

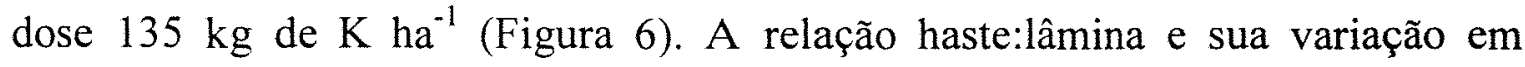
função das doses de $\mathrm{K}$ foram menores em Tifton 85 do que em Coastcross 1 . Ferrari Júnior et al. (1993) observaram que a relação haste:folha aumentou de 1,3 para 1,6 quando comparou áreas de feno de Coastcross 1 sem e com adubação de reposição (contendo nitrogênio e potássio), respectivamente. 


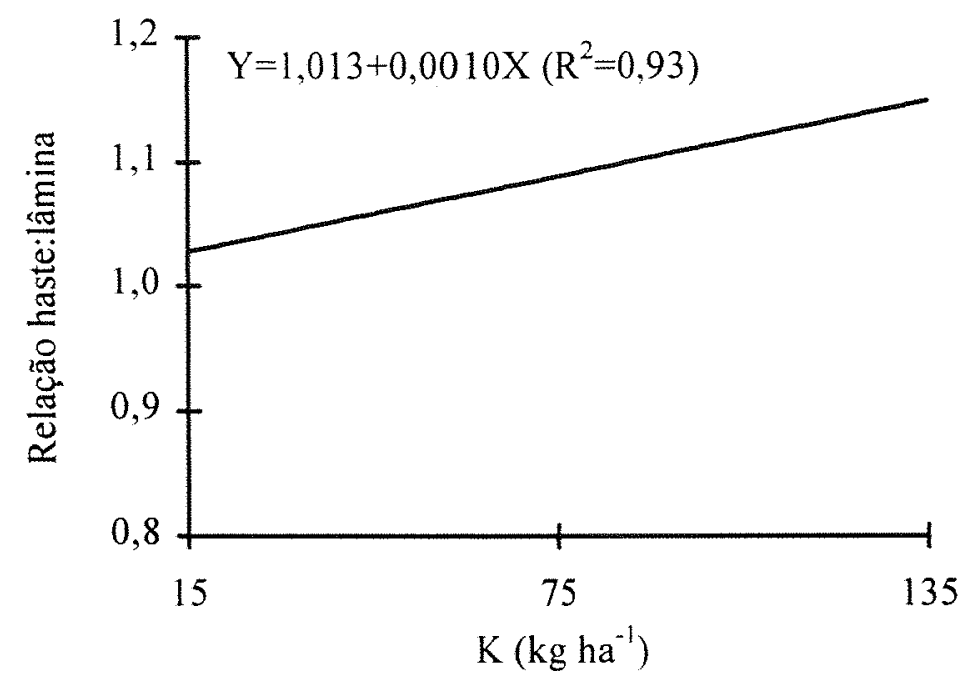

Figura 5. Relação haste:lâmina do Tifton 85 , no primeiro crescimento, em função das doses de potássio.

No segundo e terceiro crescimento a relação haste:lâmina diminuiu com a adubação nitrogenada (Figura 6 e 7), não havendo variação significativa no primeiro crescimento. A relação haste:lâmina diminuiu de 1,43 para 1,16 e de 1,09 para 1,02 com o aumento da adubação nitrogenada em Coastcross 1 no segundo e terceiro períodos de crescimento, respectivamente. No terceiro crescimento, essa relação seguiu um modelo quadrático em função das doses de potássio, como pode ser observado na Figura 8. 


\section{TIFTON 85}

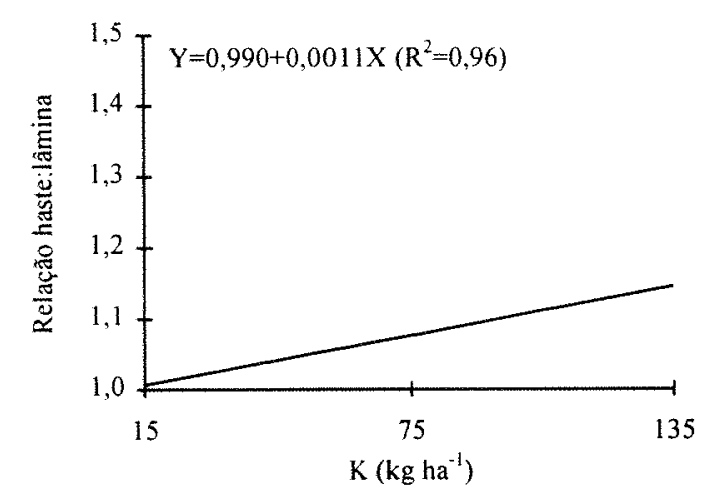

COASTCROSS 1
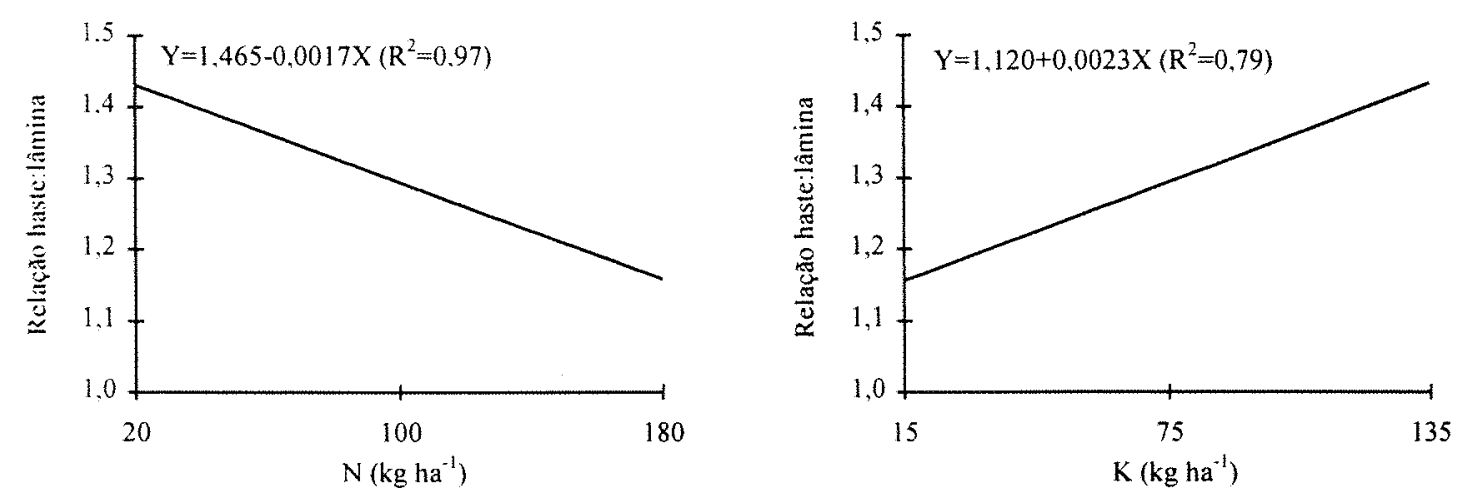

Figura 6. Relação haste:lâmina do Tifton 85 e do Coastcross 1, no segundo crescimento, em função das doses de nitrogênio e de potássio.

Nesse estudo, os capins tiveram produção de matéria seca incrementada em função das doses de nitrogênio e de potássio. O estudo da proporção haste:lâmina, no entanto, revelou que esse aumento foi proporcionalmente maior em folhas com as doses de nitrogênio e proporcionalmente maior em hastes com as doses de potássio. Segundo Jordan et al (1981), o aumento na proporção de folhas em Coastcross 1 incrementou o teor de nitrogênio e a digestibilidade desse capim. 


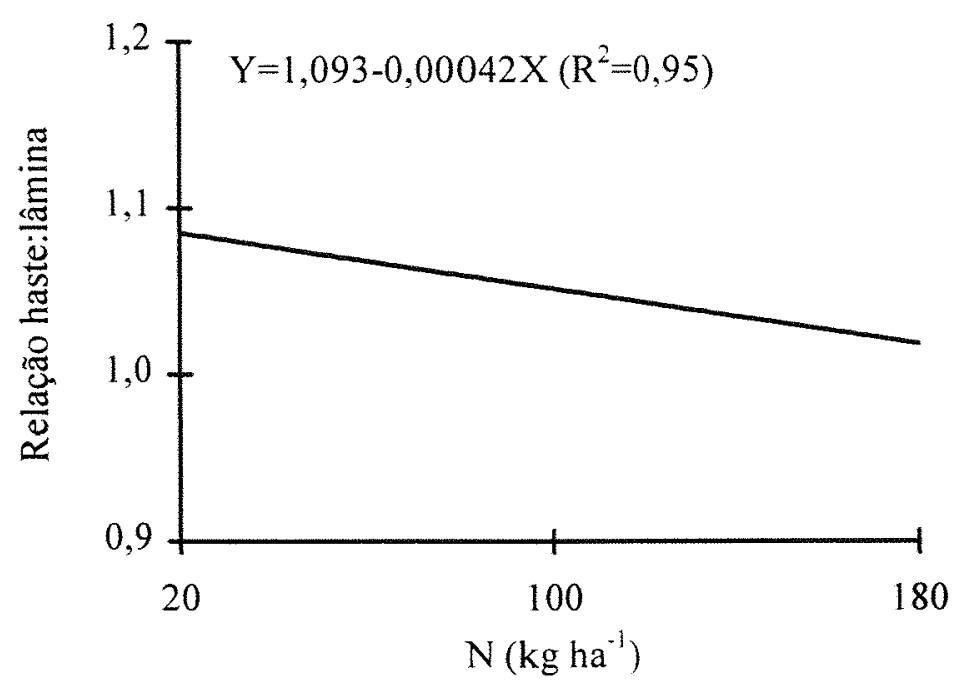

Figura 7. Média da relação haste:lâmina dos capins Tifton 85 e do Coastcross 1, no terceiro crescimento, em função das doses de nitrogênio.

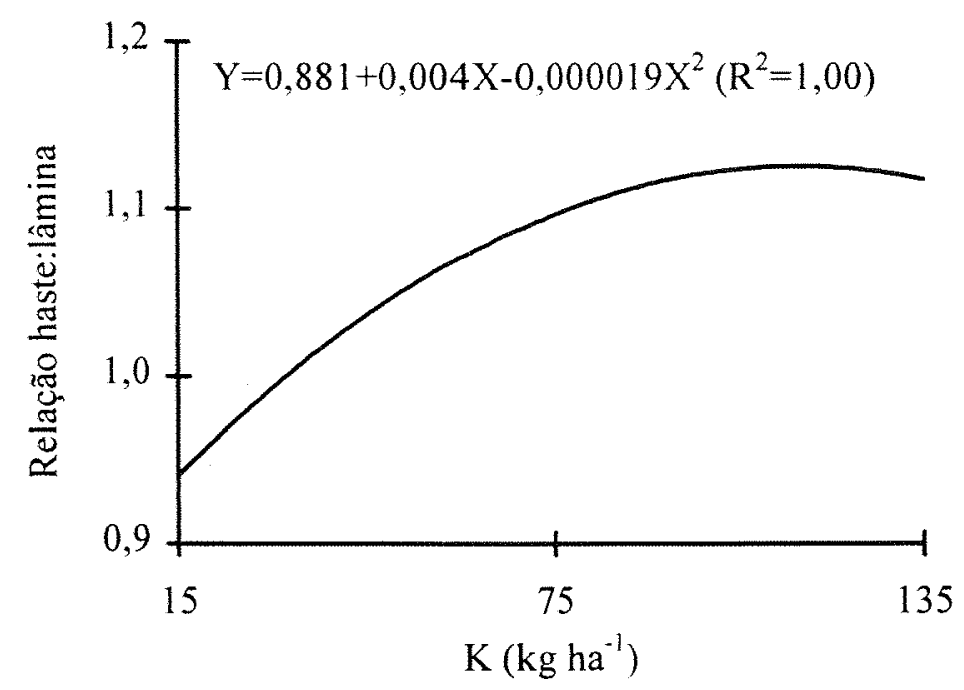

Figura 8. Média da relação haste:lâmina dos capins Tifton 85 e Coastcross 1, no terceiro crescimento, em função das doses de potássio. 
O decréscimo na relação haste:folha com a adubação nitrogenada também foi observado por Herrera (1979a), durante a estação seca. Por outro lado, Herrera e Hernandez (1979a) e Herrera e Hernandez (1985a) observaram diminuição na porcentagem de folhas em Coastcross 1 com o incremento da adubação

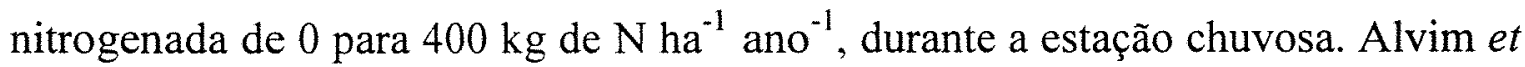
al. (1996) observaram que a relação haste:folha foi de 0,$67 ; 0,67 ; 0,77$ e 0,77 para aplicações de $0,250,500,750 \mathrm{~kg} \mathrm{~N} \mathrm{ha}^{-1} \mathrm{ano}^{-1}$, em Coastcross 1 colhido a cada quatro semanas.

A relação haste:lâmina foi significativamente mais elevada no Coastcross 1 que no Tifton 85 no primeiro (Tabela 6), segundo (Figura 9 e Tabela 6) e terceiro cortes, com exceção do nível $15 \mathrm{~kg}$ de $\mathrm{K} \mathrm{ha}^{-1}$ no primeiro corte, onde o Tifton 85 apresentou maior relação haste:lâmina do que o Coastcross 1 (Tabela 6). Os valores obtidos foram superiores ao encontrado por Vieira et al. (1980) em capim-colonião com 75 dias de crescimento; Pinto et al. (1992) em pesquisas com capim-andropogon, guiné e setária cv. Kazungula; Moura et al. (1975) com o capim-gordura e inferiores ao obtido por Ferrari Júnior et al. (1993) em estudos com o Coastcross 1 . 
Tabela 6. Relação haste:lâmina dos capins Tifton 85 e Coastcross 1, no primeiro e segundo crescimento, em função das doses de potássio.

\begin{tabular}{|c|c|c|}
\hline \multirow[t]{2}{*}{$\overline{\text { Forrageiras }}$} & \multicolumn{2}{|c|}{ Doses $\left(\mathrm{kg} \mathrm{ha}^{-1}\right)$} \\
\hline & Primeiro corte & Segundo corte \\
\hline & \multicolumn{2}{|c|}{$\mathrm{K}=15$} \\
\hline Tifton 85 & $2,47 a$ & $1,02 b$ \\
\hline \multirow[t]{2}{*}{ Coastcross 1} & $2,01 b$ & $1,11 \mathrm{a}$ \\
\hline & \multicolumn{2}{|c|}{$\mathrm{K}=75$} \\
\hline Tifton 85 & $1,07 \mathrm{~b}$ & $1,06 \mathrm{~b}$ \\
\hline \multirow{2}{*}{ Coastcross 1} & $1,31 \mathrm{a}$ & $1,38 \mathrm{a}$ \\
\hline & \multicolumn{2}{|c|}{$\mathrm{K}=135$} \\
\hline Tifton 85 & $1,16 \mathrm{~b}$ & $1,15 b$ \\
\hline Coastcross 1 & $1,23 \mathrm{a}$ & $1,39 \mathrm{a}$ \\
\hline
\end{tabular}

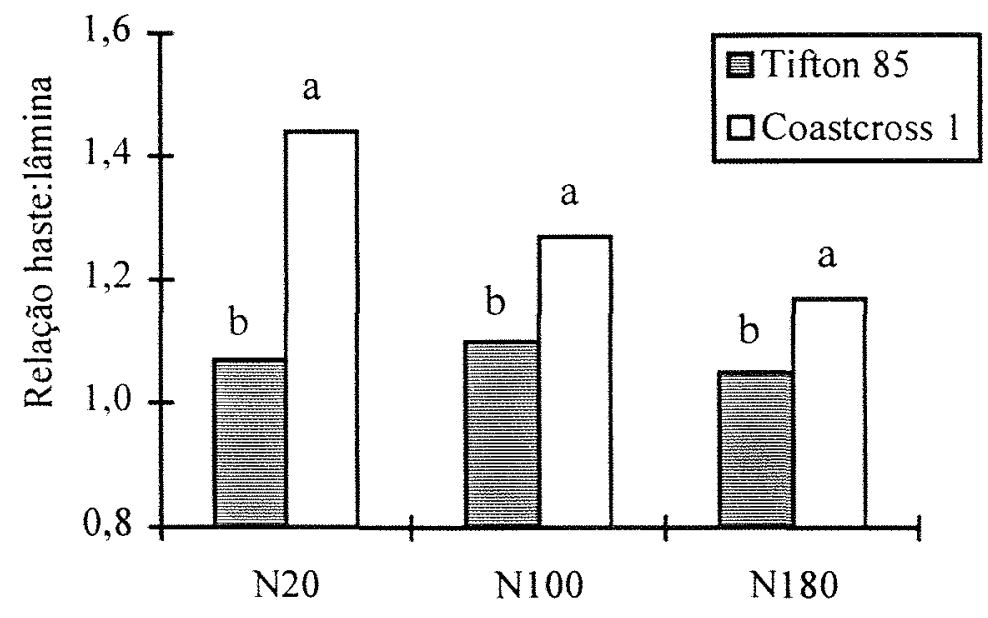

Figura 9. Relação haste:lâmina do Tifton 85 e do Coastcross 1, no segundo crescimento, em função das doses de nitrogênio (médias seguidas de letras diferentes dentro da mesma dose de nitrogênio diferem estatisticamente a $5 \%$ de probabilidade pelo teste de Tukey). 


\subsection{Concentração de nitrogênio nos tecidos vegetais}

O Tifton 85 apresentou maior concentração de nitrogênio $(P<0,05)$ do que o Coastcross 1 no primeiro crescimento (Figura 11 e 10) e no terceiro crescimento apenas para as doses de $100 \mathrm{~kg}$ de $\mathrm{N}$ e $135 \mathrm{~kg}$ de $\mathrm{K} \mathrm{ha}^{-1}$ (Tabela 7). No segundo crescimento não houve diferença significativa $(\mathrm{P}>0,05)$ para concentração de nitrogênio entre os capins estudados. Pedreira (1995) observou que o teor de nitrogênio em Tifton 85 foi de $19,5 \mathrm{~g} \mathrm{~kg}^{-1}$ e em Florakirk (Cynodon dactylon) foi de $21,1 \mathrm{~g} \mathrm{~kg}^{-1}$. Em estudos com o Tifton 85 , Hill et al. (1993), obtiveram 22,6 g $\mathrm{kg}^{-1}$ como média no teor de nitrogênio desse capim.

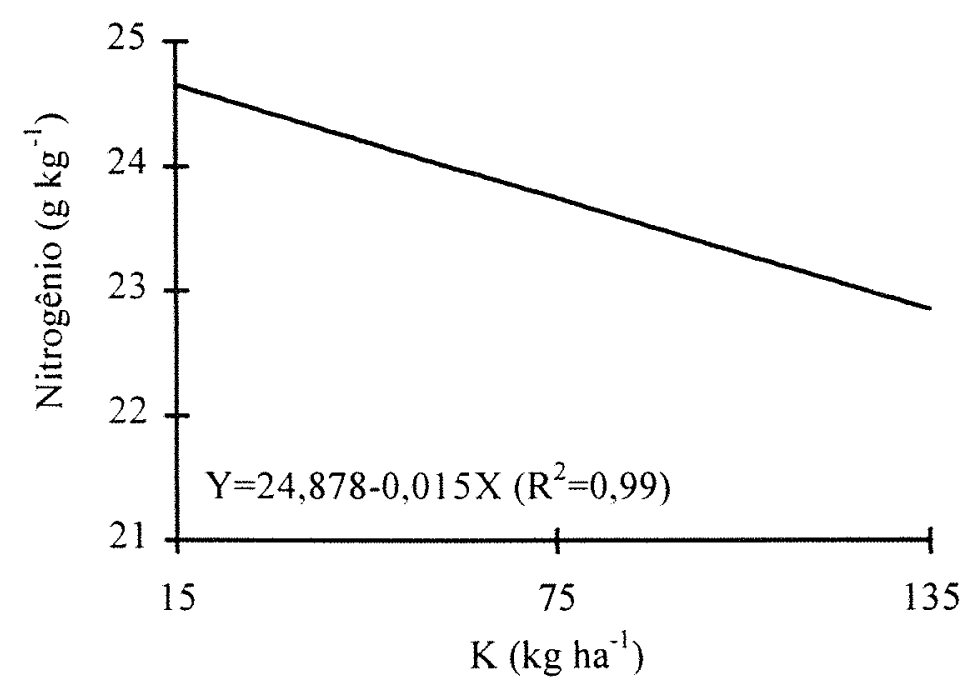

Figura 10. Concentração de nitrogênio na parte aérea do Tifton 85 , no primeiro corte, em função das doses de potássio. 


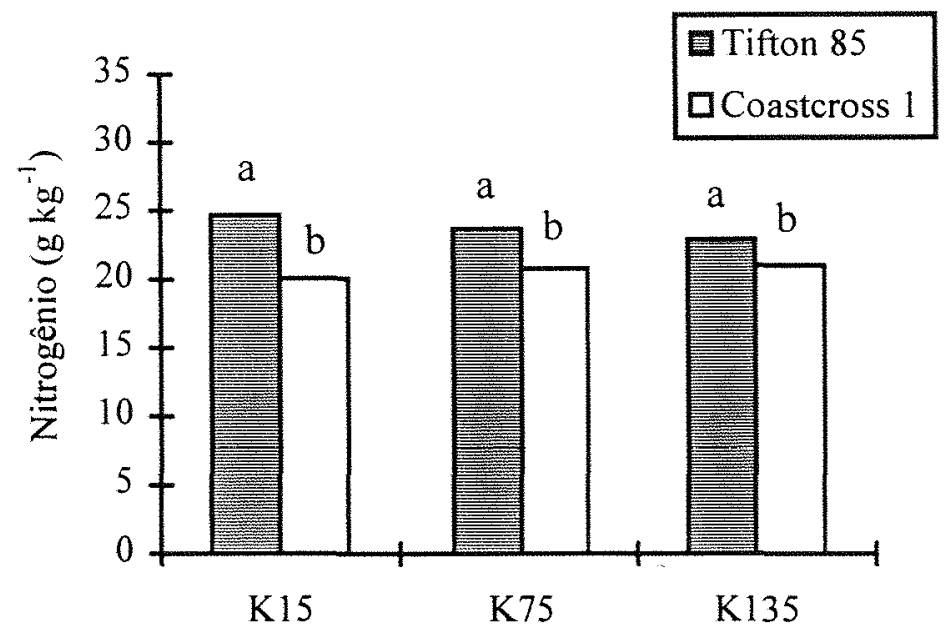

Figura 11. Concentração de nitrogênio $\left(\mathrm{g} \mathrm{kg}^{-1}\right)$ na parte aérea dos capins Tifton 85 e Coastcross 1 , no primeiro corte, em função das doses de potássio (médias seguidas de letras diferentes dentro da mesma dose de potássio diferem a $5 \%$ de probabilidade pelo teste de Tukey).

Tabela 7. Concentração de nitrogênio $\left(\mathrm{g} \mathrm{kg}^{-1}\right)$ na parte aérea dos capins Tifton 85 e Coastcross 1, no terceiro corte, em função das doses de nitrogênio e de potássio.

\begin{tabular}{l|c|c|c}
\hline \multirow{2}{*}{ Forrageiras } & \multicolumn{3}{|c}{ Doses $\left(\mathrm{kg} \mathrm{ha}^{-1}\right)$} \\
\cline { 2 - 4 } & $\mathrm{N}=20$ & $\mathrm{~N}=100$ & $\mathrm{~N}=180$ \\
\hline \multirow{2}{*}{ Tifton 85} & $10,04 \mathrm{a}$ & $15,71 \mathrm{a}$ & $19,25 \mathrm{~b}$ \\
Coastcross 1 & $10,81 \mathrm{a}$ & $15,61 \mathrm{a}$ & $21,56 \mathrm{a}$ \\
\hline & \multicolumn{3}{|c}{$\mathrm{K}=75$} \\
\hline Tifton 85 & $9,13 \mathrm{a}$ & $13,23 \mathrm{a}$ & $18,69 \mathrm{a}$ \\
Coastcross 1 & $9,10 \mathrm{a}$ & $16,20 \mathrm{a}$ & $15,57 \mathrm{a}$ \\
\hline \multicolumn{4}{|c}{$\mathrm{K}=135$} \\
\hline Tifton 85 & $9,17 \mathrm{a}$ & $12,46 \mathrm{a}$ & $17,01 \mathrm{a}$ \\
Coastcross 1 & $8,89 \mathrm{a}$ & $11,13 \mathrm{~b}$ & $16,94 \mathrm{a}$ \\
\hline Médias seguidas de letras diferentes na mesma subcoluna diferem \\
estatisticamente a 5\% de probabilidade pelo teste de Tukey.
\end{tabular}


No segundo crescimento a concentração de nitrogênio aumentou linearmente $(\mathrm{P}<0,01)$ de 10,5 para $17,6 \mathrm{~g} \mathrm{~kg}^{-1}$ quando as doses de nitrogênio foram de 20 para $180 \mathrm{~kg}$ de $\mathrm{N} \mathrm{ha}^{-1}$ corte $^{-1}$ (Figura 12). O mesmo comportamento foi verificado em Coastcross 1 e em Tifton 85 no terceiro crescimento (Figura 14). Alvim et al. (1996) observaram que o teor de nitrogênio em Coastcross 1 cortado a cada quatro semanas aumentou com as doses de nitrogênio, sendo que o teor foi de 21,$6 ; 21,8 ; 28,2$ e $30,6 \mathrm{~g} \mathrm{~kg}^{-1}$, para as doses de $0,250,500$ e $750 \mathrm{~kg}$ de $\mathrm{N} \mathrm{ha}^{-1}$ ano $^{-1}$ durante a estação chuvosa e 19,$8 ; 21,0 ; 27,0$ e $28,6 \mathrm{~g} \mathrm{~kg}^{-1}$, para as doses de $0,250,500$ e $750 \mathrm{~kg}_{\text {de }} \mathrm{N} \mathrm{ha}^{-1}$ ano $^{-1}$ na estação seca do ano.

A concentração de nitrogênio obtida nas doses mais baixas de nitrogênio são muito próximas às concentrações referidas por Alcântara et al. (1981), onde teor de nitrogênio foi de $10,0 \mathrm{~g} \mathrm{~kg}^{-1}$ em Coastcross $1 \mathrm{com} 60$ dias de crescimento e adubado com $200 \mathrm{~kg}$ de $\mathrm{N} \mathrm{ha}^{-1}$ ano $^{-1}$ e por Gomide et al. (1987) em capimcolonião (13,3 $\left.\mathrm{g} \mathrm{kg}^{-1}\right)$ e em jaraguá $\left(10,4 \mathrm{~g} \mathrm{~kg}^{-1}\right)$; mas são superiores ao observado por Gomide et al. (1987) em braquiária decumbens $\left(4,1 \mathrm{~g} \mathrm{~kg}^{-1}\right)$.

Não foi observada variação na concentração do nitrogênio $(P>0,05)$ em função das doses de nitrogênio no primeiro crescimento. Essa afirmação discorda de Bufarah et al. (1982), Ferrari Júnior et al. (1993), Herrera (1979a), Herrera (1979b), Herrera e Hernandez (1985b), os quais relataram que a concentração do nitrogênio nas plantas aumentou com o incremento na adubação nitrogenada. Esse fato ocorreu provavelmente devido ao desenvolvimento mais lento das plantas durante a fase de estabelecimento, causando maior acúmulo do nitrogênio nos tecidos e afetando a variação no teor desse nutriente em função da adubação nitrogenada. O primeiro crescimento foi também o período onde as plantas, particularmente o Tifton 85 , acumularam mais nitrogênio. 


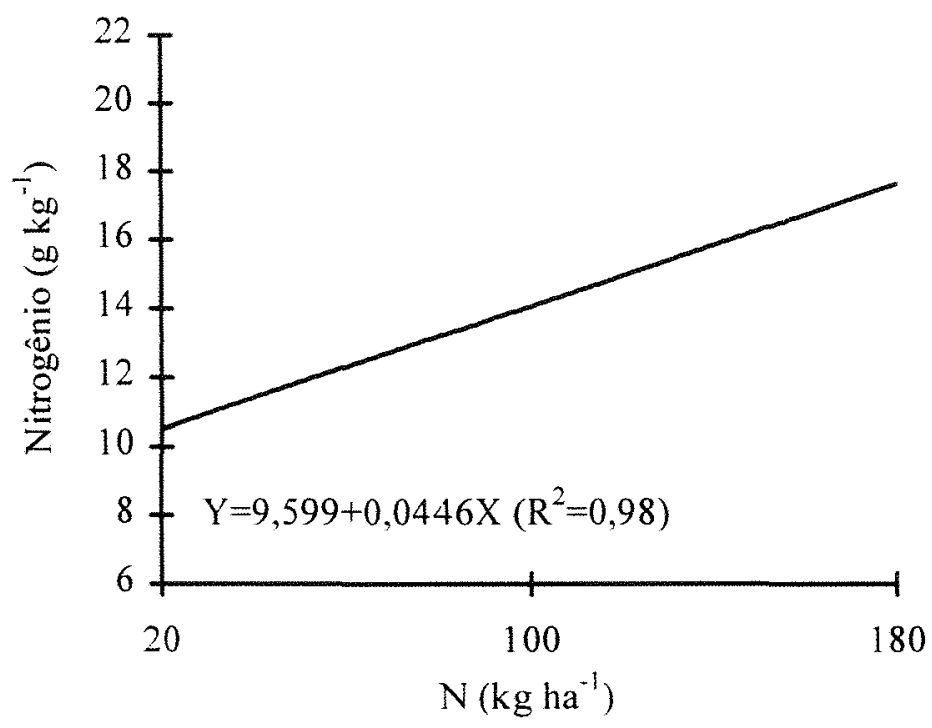

Figura 12. Média da concentração de nitrogênio na parte aérea dos capins Tifton 85 e Coastcross 1 , no segundo corte, em função das doses de nitrogênio.

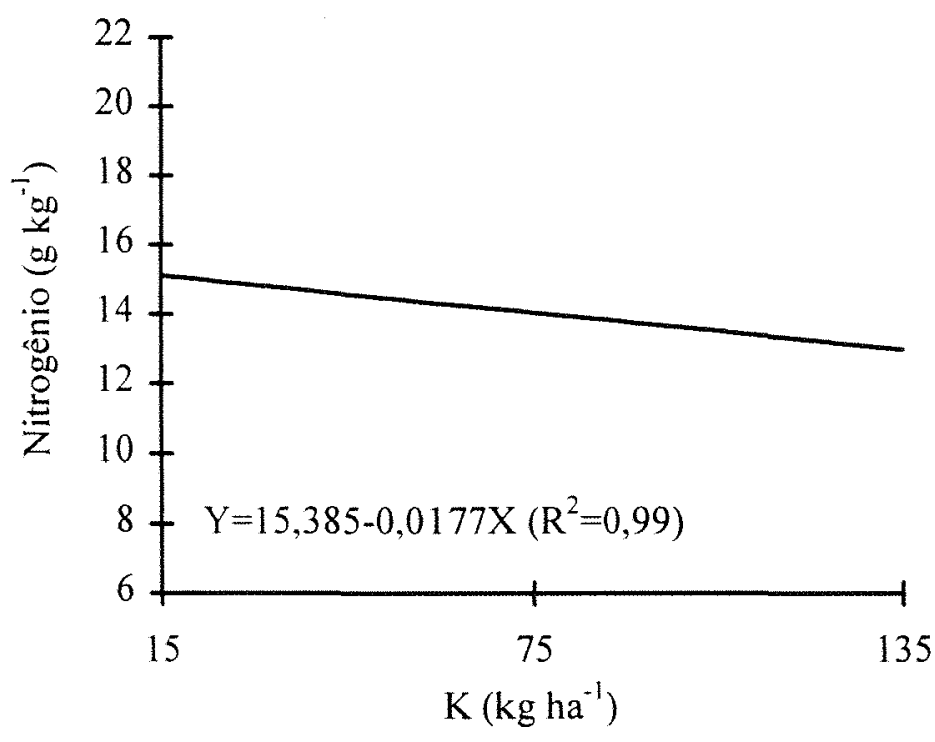

Figura 13. Média da concentração de nitrogênio na parte aérea dos capins Tifton 85 e Coastcross 1 , no segundo corte, em função das doses de potássio. 


\section{TIFTON 85}
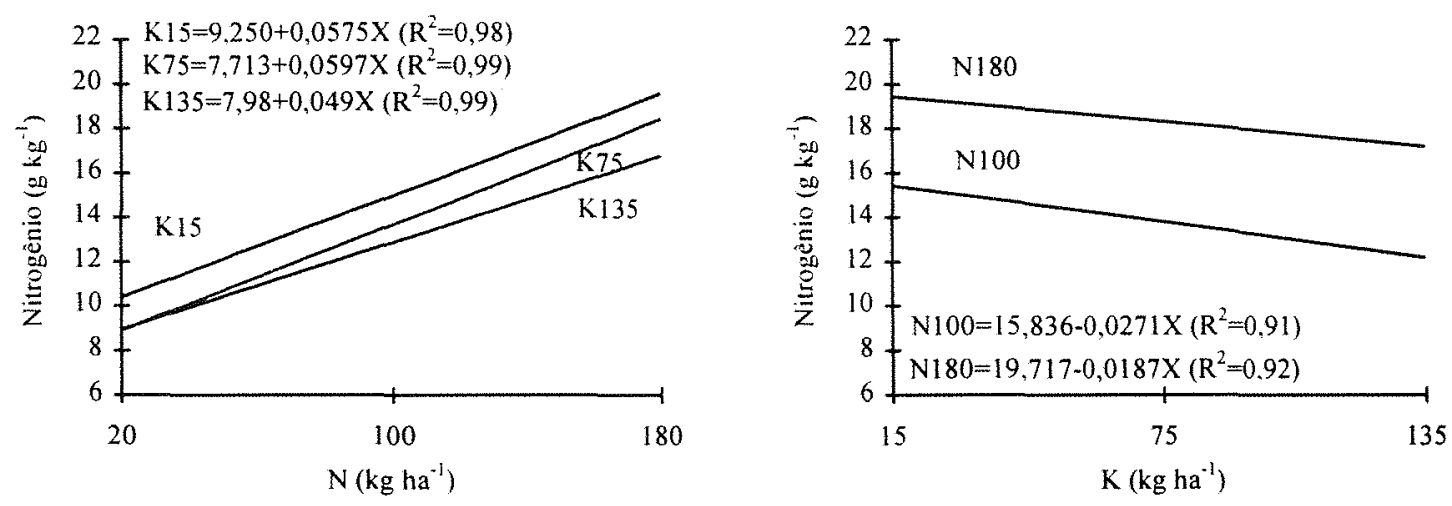

COASTCROSS 1

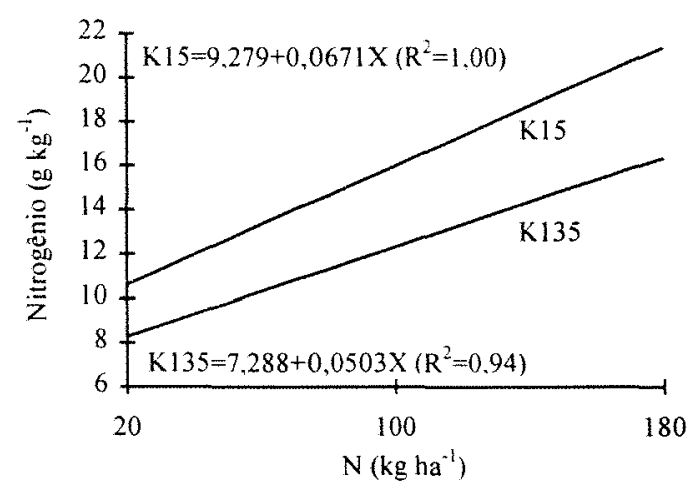

Figura 14. Concentração de nitrogênio na parte aérea do Tifton 85 e do Coastcross 1, no terceiro corte, em função das doses de nitrogênio e de potássio.

Mesmo no primeiro crescimento, onde as concentrações de nitrogênio obtidas em ambos capins foram mais elevadas do que nos demais periodos de crescimento, os valores foram inferiores aos verificados por Utley et al. (1971) e Monson e Burton (1982) em Coastcross 1 (28,0 $\left.\mathrm{g} \mathrm{kg}^{-1}, 33,0 \mathrm{~g} \mathrm{~kg}^{-1}\right)$; Coastal $(26,9$ $\left.\mathrm{g} \mathrm{kg}^{-1}, 27,5 \mathrm{~g} \mathrm{~kg}^{-1}\right)$; Callie $\left(31,7 \mathrm{~g} \mathrm{~kg}^{-1}\right)$, Tifton $68\left(31,5 \mathrm{~g} \mathrm{~kg}^{-1}\right)$, Midland $(28,8 \mathrm{~g}$ $\left.\mathrm{kg}^{-1}\right)$ e Tifton $44\left(27,2 \mathrm{~g} \mathrm{~kg}^{-1}\right)$. 
Palhano (1990) obteve teor de 27,4 $\mathrm{g} \mathrm{kg}^{-1}$ em Coastcross 1 cortado a cada 30 dias e adubado com $250 \mathrm{~kg}$ de $\mathrm{N}$ e $250 \mathrm{~kg} \mathrm{de} \mathrm{K} \mathrm{ha}^{-1}$ ano $^{-1}$, sendo mais elevado do que o obtido no presente estudo. Schank et al. (1977), em estudos com o Coastcross 1 , verificou concentração de nitrogênio de $24,3 \mathrm{~g} \mathrm{~kg}^{-1}$, semelhante ao encontrado em Coastcross 1 e Tifton 85 no primeiro corte mas superior ao obtido no segundo e terceiro cortes no presente trabalho.

Foi verificado decréscimo $(\mathrm{P}<0,05)$ na concentração do nitrogênio na parte aérea somente em Tifton 85, com o aumento das doses de potássio no primeiro e terceiro crescimento (Figura 10 e Figura 14) e em ambos capins no segundo crescimento (Figura 13). Através da análise da interação tripla $(\mathrm{P}<0,01)$ entre nitrogênio $\mathrm{x}$ potássio $\mathrm{x}$ cultivares obtida no terceiro crescimento, pode-se observar que tanto menor foi a concentração de nitrogênio quanto maior a dose de potássio utilizada em ambos cultivares (Figura 14). Esse fato pode ter se sucedido devido ao maior desenvolvimento atingido pelas plantas nas doses mais altas de potássio, causando um efeito de diluição na concentração de nitrogênio nos tecidos dos capins. Mesa et al. (1989) também observaram queda na concentração de nitrogênio nos tecidos de Cynodon dactylon cv. 68 com o aumento nas doses de

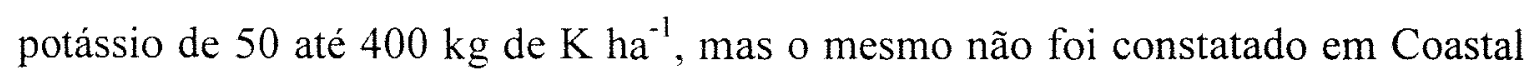
por Eichhorn e Nelson (1988), utilizando doses de até $500 \mathrm{~kg}$ de $\mathrm{K} \mathrm{ha}^{-1}$.

Os sintomas de deficiência de nitrogênio apareceram a partir do primeiro crescimento em Coastcross 1 e a partir do segundo crescimento em Tifton 85. Tais sintomas foram caracterizados pela clorose generalizada das folhas dos capins, porém pouco perceptível em Tifton 85 devido a cor azulada de suas folhas. 
Em ambos os cultivares ocorreu clorose das folhas mais velhas, iniciandose na ponta em direção à base das mesmas. Porém, tal observação foi muito mais rara em Tifton 85 (Figura 15).

Os sintomas foram verificados nos tratamentos com mais baixa dose de nitrogênio, durante o segundo e terceiro períodos de crescimento, e por volta de 10 e 5 dias antes de cada corte em Coastcross 1 e em Tifton 85, respectivamente. Essas informações concordam com o descrito por Malavolta et al. (1986) onde relatam que a deficiência de nitrogênio em gramíneas forrageiras causa menor desenvolvimento das plantas, menor perfilhamento e clorose nas folhas mais velhas.

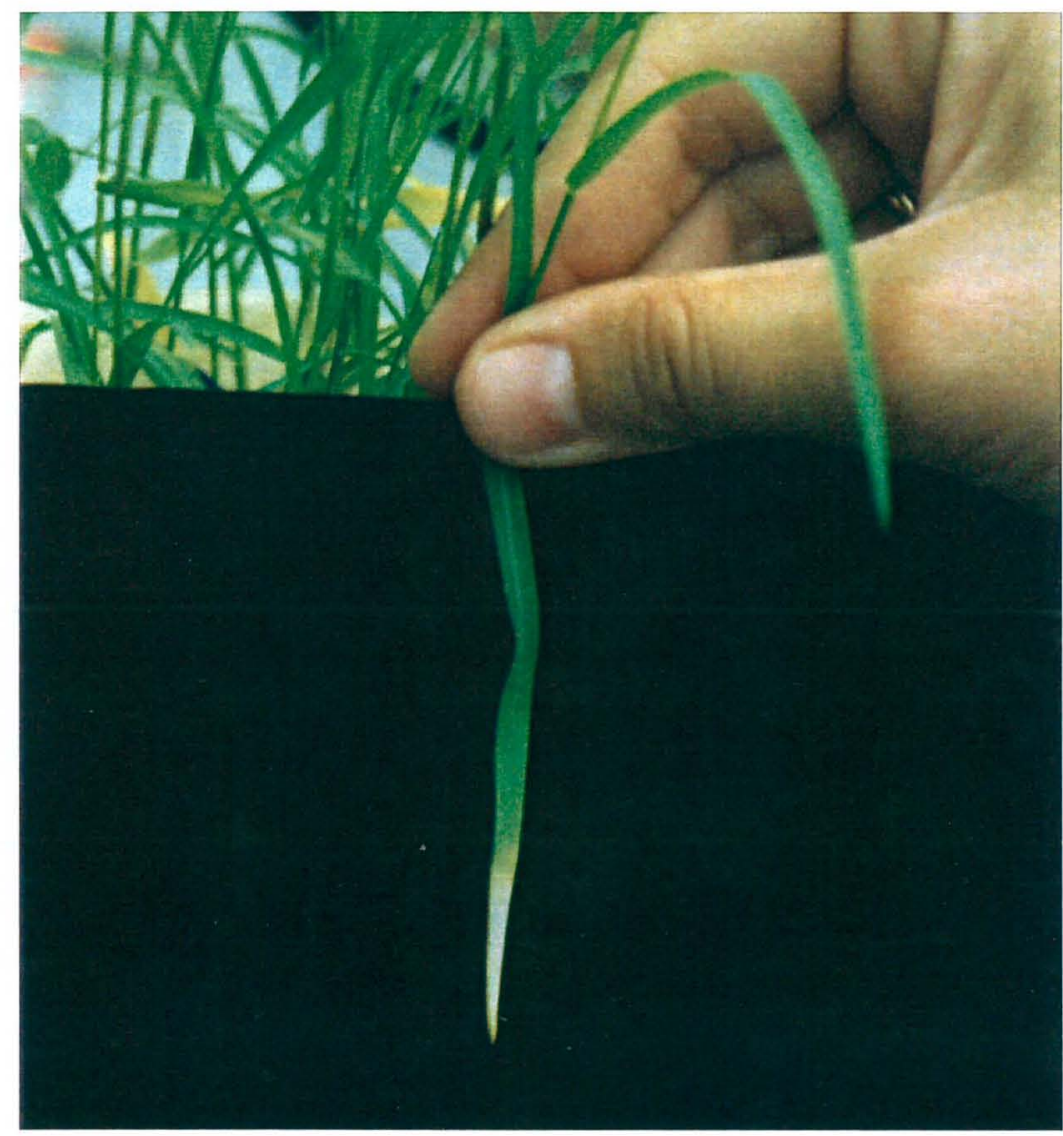

Figura 15. Sintomas de deficiência de nitrogênio em Coastcross 1, verificado no terceiro crescimento no tratamento $20 \mathrm{~kg}$ de $\mathrm{N}$ e $135 \mathrm{~kg}$ de $\mathrm{K} \mathrm{ha}^{-1}$. 
A concentração de nitrogênio nas raízes variou com a adubação nitrogenada, seguindo um modelo quadrático (Figura 16). Também foi observada maior concentração $(\mathrm{P}<0,01)$ de nitrogênio nas raízes de Tifton $85\left(10,9 \mathrm{~g} \mathrm{~kg}^{-1}\right)$ do que em Coastcross $1\left(9,8 \mathrm{~g} \mathrm{~kg}^{-1}\right)$. Abreu (1994) observou que os teores mínimo e máximo de nitrogênio nas raízes dos capins gordura, braquiária Marandu e Tanzânia-1 foram de $8 \mathrm{~g} \mathrm{~kg}^{-1}$ e $16 \mathrm{~g} \mathrm{~kg}^{-1}$, com a utilização de 97 e $210 \mathrm{mg}$ de $\mathrm{NO}_{3}{ }^{-} \mathrm{L}^{-1}$ de solução, respectivamente.

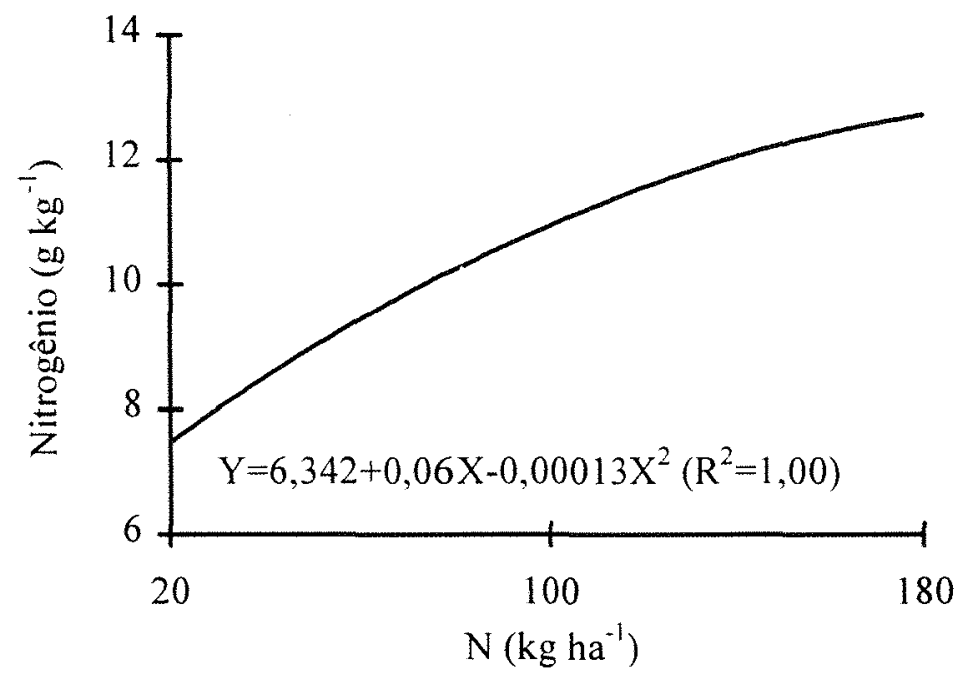

Figura 16. Média da concentração de nitrogênio nas raízes do Tifton 85 e do Coastcross 1, em função das doses de nitrogênio.

\subsection{Concentração de potássio nos tecidos vegetais}

O teor de potássio na parte aérea dos capins aumentou com a adubação potássica no primeiro e segundo crescimento (Figuras 17 e 19). Houve uma variação nos capins de 13,4 para $17,4 \mathrm{~g} \mathrm{~kg}^{-1}$ e de 3,7 para $13,3 \mathrm{~g} \mathrm{~kg}^{-1}$, representando aumentos de 30 e $259 \%$ no primeiro e segundo cortes, respectivamente. Segundo Adams et al. (1967), adubações de 0 até $740 \mathrm{~kg}$ de 
$\mathrm{K} \mathrm{ha}^{-1}$ incrementaram o teor de potássio de Coastal mais acentuadamente $(300 \%)$ do que a produção de matéria seca (66\%).

No terceiro crescimento o Tifton 85 e o Coastcross 1, apesar de apresentarem aumento na produção de matéria seca com as doses de potássio, não mostraram aumento na concentração de potássio nos tecidos. Esse resultado pode ser um indicativo de que, nessas condições, a produção de matéria seca possivelmente seria incrementada com doses mais elevadas de potássio.

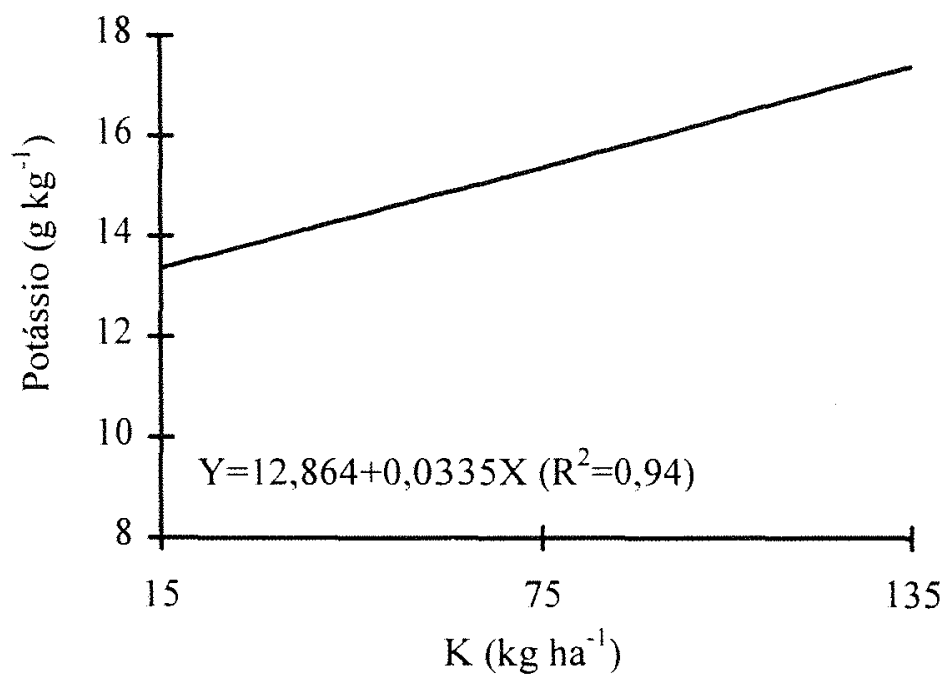

Figura 17. Média da concentração de potássio na parte aérea dos capins Tifton 85 e Coastcross 1, no primeiro crescimento, em função das doses de potássio.

Houve diminuição no teor de potássio em função da adubação nitrogenada, no segundo e terceiro crescimentos (Figura 18 e 20). A adubação nitrogenada promoveu um grande aumento na produção de matéria seca desses capins, o que pode ter causado uma diluição na concentração do potássio nessas forrageiras. $O$ mesmo foi constatado por Herrera e Hernandez (1985b) em pesquisas com o 
Coastcross 1 e por Gonzalez et al. (1983), os quais verificaram teores de potássio de 14,$2 ; 17,6$ e $12,7 \mathrm{~g} \mathrm{~kg}^{-1}$ em Coastcross 1 e de 14,$5 ; 11,3$ e $10,3 \mathrm{~g} \mathrm{~kg}^{-1} \mathrm{em}$ Coastal, adubados com 0,200 e $400 \mathrm{~kg}$ de $\mathrm{N} \mathrm{ha}^{-1}$.

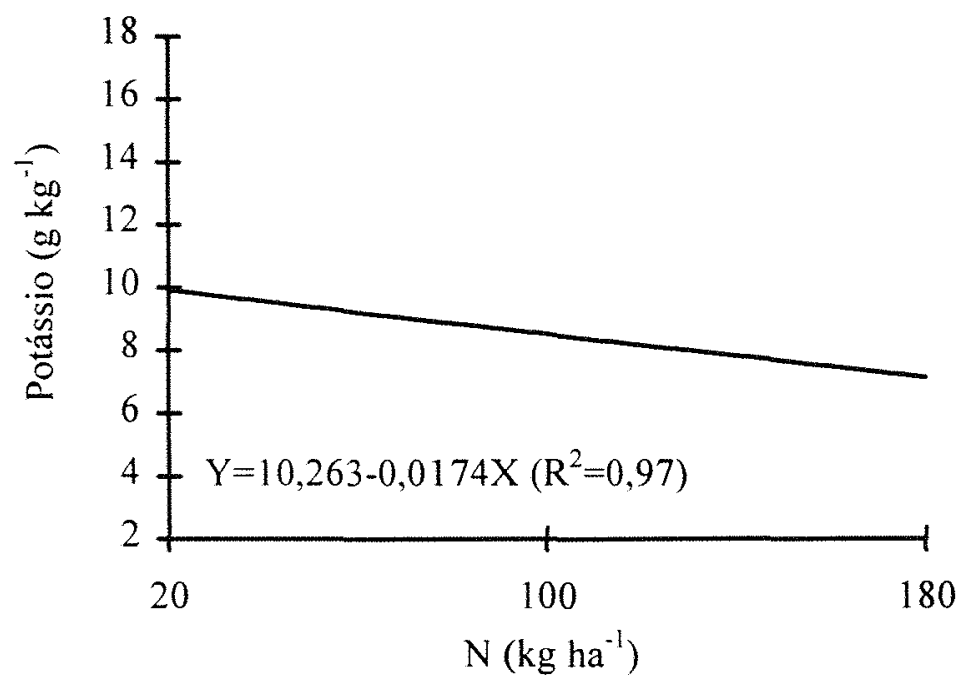

Figura 18. Média da concentração de potássio na parte aérea dos capins Tifton 85 e Coastcross 1, no segundo crescimento, em função das doses de nitrogênio. 


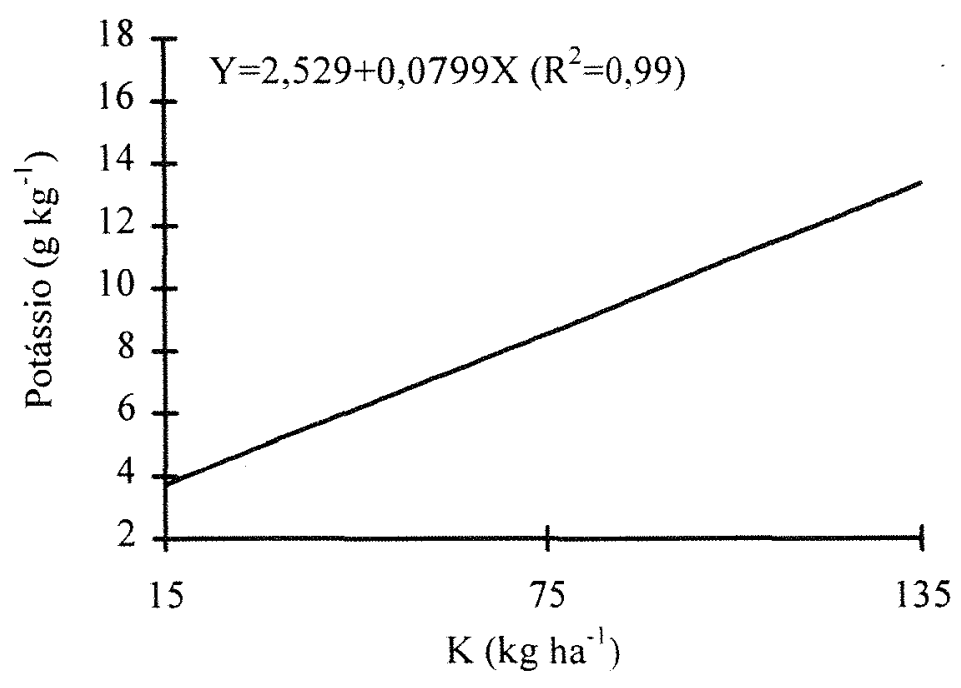

Figura 19. Média da concentração de potássio na parte aérea dos capins Tifton 85 e Coastcross 1, no segundo crescimento, em função das doses de potássio.

Observando-se a Figura 20 e 21, é possivel verificar que o Coastcross 1 acumulou mais potássio no nível mais baixo de nitrogênio, mas decresceu mais subitamente em função da adubação nitrogenada do que em Tifton 85. O ocorrido indica que o Coastcross 1 foi mais exigente em potássio para a maior dosagem de nitrogênio do que o Tifton 85 , como também foi verificado em relação a produção de matéria seca. 


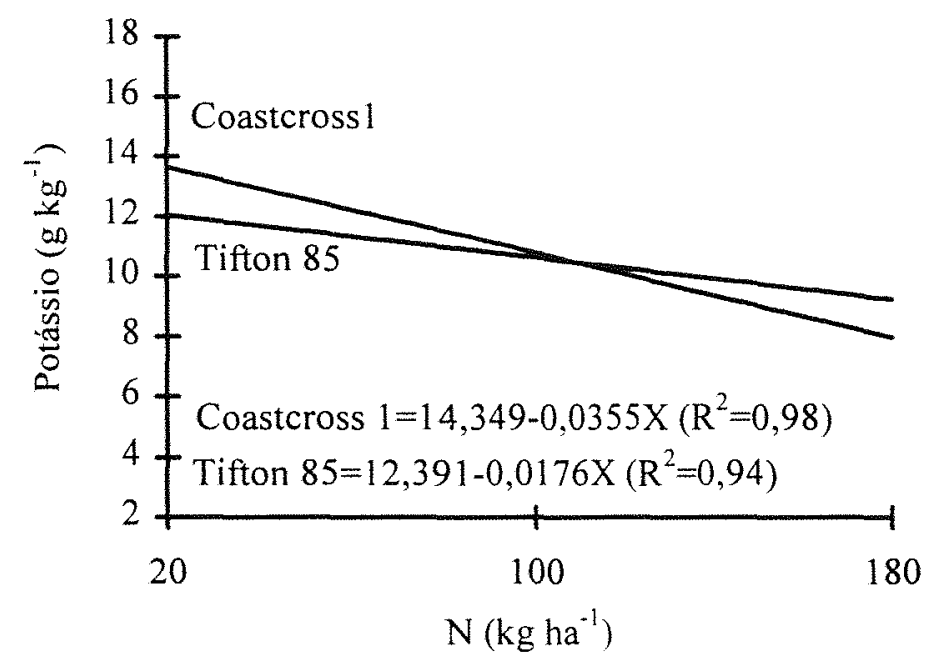

Figura 20. Concentração de potássio na parte aérea do Tifton 85 e do Coastcross 1, no terceiro crescimento, em função das doses de nitrogênio.

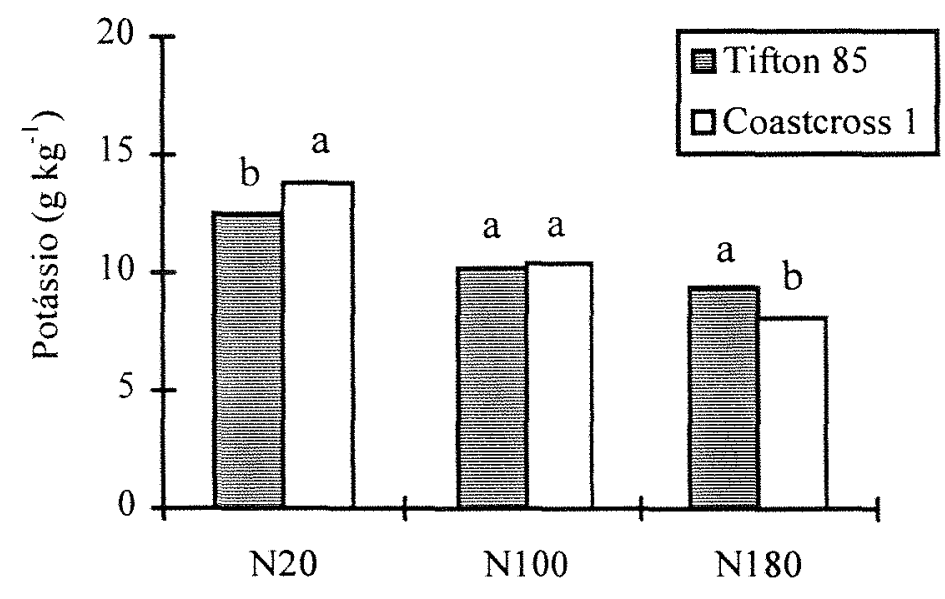

Figura 21. Concentração de potássio $\left(\mathrm{g} \mathrm{kg}^{-1}\right)$ na parte aérea dos capins Tifton $85 \mathrm{e}$ Coastcross 1, no terceiro crescimento, em função das doses de nitrogênio (médias seguidas de letras diferentes dentro da mesma dose de nitrogênio diferem estatisticamente a $5 \%$ de probabilidade pelo teste de Tukey). 
As mais altas concentrações de potássio obtidas no segundo e terceiro cortes foram semelhantes às observadas por Gonzalez et al. (1983) em Coastal e Coastcross 1 adubados com $83 \mathrm{~kg}$ de $\mathrm{K} \mathrm{ha}^{-1}$. Gomide et al. (1969) obtiveram teor de potássio de $11,7 \mathrm{~g} \mathrm{~kg}^{-1}$ em Swannee sem adubação, as quais foram superiores aos obtidos em Coastcross 1 e Tifton 85 para a dose $15 \mathrm{~kg}$ de $\mathrm{K} \mathrm{ha}^{-1}$, especialmente no segundo e terceiro crescimentos no presente trabalho. Esse fato pode ser resultado do baixo teor de potássio no solo $\left(0,13 \mathrm{cmol}_{\mathrm{c}} \mathrm{dm}^{-3}\right)$ e da alta exigência em potássio dessas plantas. Palhano (1990) encontrou teor médio de $17,0 \mathrm{~g} \mathrm{~kg}^{-1}$ de potássio em Coastcross 1 com 30 dias de crescimento e adubado com $250 \mathrm{~kg}$ de $\mathrm{K} \mathrm{ha}^{-1}$.

Semelhante ao observado na parte aérea, nas raízes ocorreu incremento no teor de potássio com a adubação potássica e decréscimo com a adubação nitrogenada (Figura 22). O acúmulo de potássio foi sempre maior para a mais alta dose de potássio e mais baixa dose de nitrogênio aplicada, não havendo diferença significativa $(\mathrm{P}>0,05)$ entre os cultivares estudados.
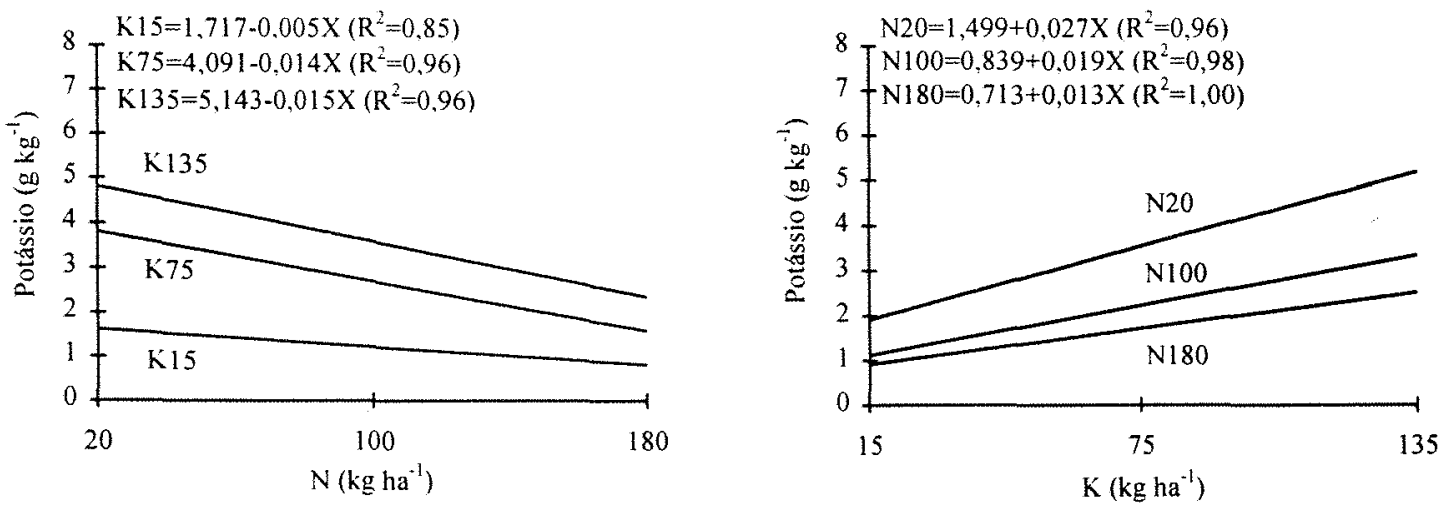

Figura 22. Média da concentração de potássio nas raízes dos capins Tifton 85 e Coastcross 1 , em função das doses de nitrogênio e de potássio. 
Os sintomas de deficiência de potássio apareceram no tratamento com a mais baixa dose de potássio e foram observados a partir do primeiro crescimento em Coastcross 1 e do segundo crescimento em Tifton 85.

O sintoma de deficiência de potássio foi semelhante nos dois capins, porém diferente do sintoma de deficiência de nitrogênio. Numa primeira fase, as folhas mais velhas sofreram clorose da ponta em direção a base e em seguida enrolavamse (Figura 23), enquanto que as folhas mais velhas dos capins deficientes em nitrogênio permaneceram expandidas. Numa segunda fase, as folhas tornaram-se completamente cloróticas e senesceram.

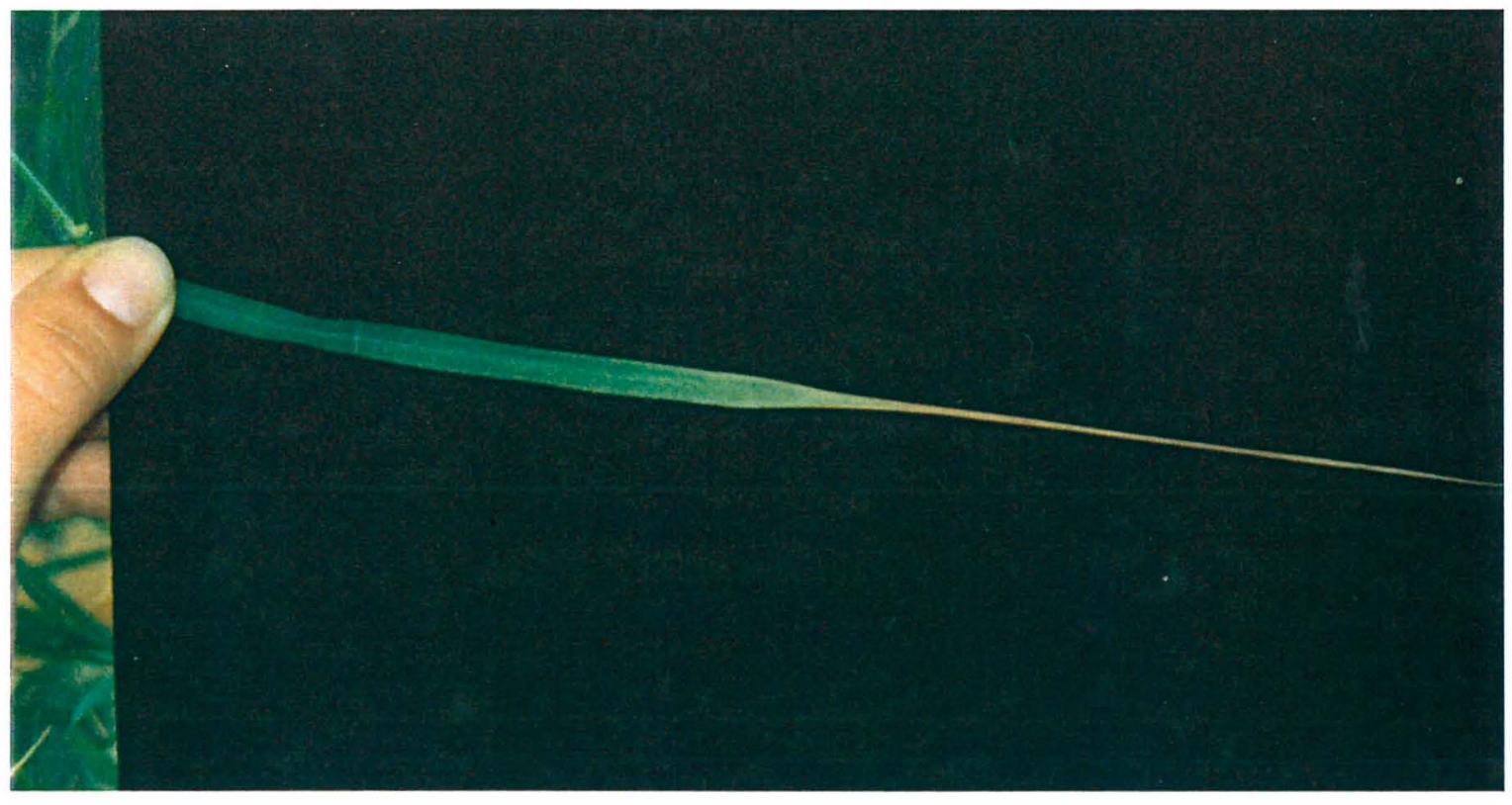

Figura 23. Sintomas de deficiência de potássio em Tifton 85, verificados no segundo crescimento no tratamento $180 \mathrm{~kg}$ de $\mathrm{N}$ e $15 \mathrm{~kg}$ de $\mathrm{K} \mathrm{ha}^{-1}$. 


\subsection{Concentração de fósforo nos tecidos vegetais}

No primeiro crescimento a concentração de fósforo na parte aérea dos capins foi maior $(\mathrm{P}<0,05)$ em Tifton $85\left(1,1 \mathrm{~g} \mathrm{~kg}^{-1}\right)$ do que em Coastcross $1(0,8 \mathrm{~g}$ $\left.\mathrm{kg}^{-1}\right)$, porém, no terceiro crescimento, foi menor em Tifton $85\left(0,7 \mathrm{~g} \mathrm{~kg}^{-1}\right)$ que o Coastcross $1\left(0,8 \mathrm{~g} \mathrm{~kg}^{-1}\right)$. Esses valores foram inferiores ao observado Pedreira $\mathrm{e}$ Mattos (1981), que encontraram teor de fósforo de $2,5 \mathrm{~g} \mathrm{~kg}^{-1}$ em Coastcross 1 adubado com $44 \mathrm{~kg}$ de $\mathrm{P} \mathrm{ha}^{-1}$ ano $^{-1}$ em um Podzolico Vermelho-Amarelo. O Coastcross 1, cultivado em um solo Latossolo Roxo distrófico, também apresentou concentração média de fósforo de $2,5 \mathrm{~g} \mathrm{~kg}^{-1}$, aos 30 dias de crescimento (Palhano, 1990).

Apesar de ter sido aplicada uma dose elevada de fósforo no início do experimento (120 kg de $\mathrm{P} \mathrm{ha}^{-1}$ ) esta parece ter sido insuficiente para as plantas nesse tipo de solo uma vez que os teores encontrados na parte aérea e raízes dos capins são relativamente baixos. Esse fato pode ter sido causado pela alta capacidade de fixação de fósforo desse solo, que teria deixado menos fósforo disponível às raízes dos capins.

A concentração de fósforo também diminuiu em função das doses de potássio, no segundo e terceiro crescimento (Figura 24 e 26), sendo que no segundo crescimento o teor mínimo de fósforo foi obtido com a dose de $95 \mathrm{~kg}$ de $\mathrm{K} \mathrm{ha}^{-1}$ corte $^{-1}$. No terceiro crescimento o teor de fósforo variou em função da adubação nitrogenada (Figura 25), onde o menor valor foi obtido com o fornecimento de $180 \mathrm{~kg} \mathrm{ha}^{-1}$ corte $^{-1}$. O aumento da produção de matéria seca dos capins em função das doses de nitrogênio e de potássio pode ter induzido a um aumento da necessidade da planta em fósforo. Uma vez que a maior parte do fósforo aplicado possivelmente encontrava-se indisponível devido à retenção no 
solo, sua concentração foi diluída com o incremento nas adubações potássica e nitrogenada.

Nas raízes o teor de fósforo apresentou comportamento similar ao da parte aérea com as doses de nitrogênio (Figura 27) e foi mais elevado $(\mathrm{P}<0,05)$ em Tifton $85\left(0,5 \mathrm{~g} \mathrm{~kg}^{-1}\right)$ do que em Coastcross $1\left(0,4 \mathrm{~g} \mathrm{~kg}^{-1}\right)$. Monteiro et al. (1995b), cultivando o capim-braquiária cv. Marandu em solução nutritiva, obtiveram teor de fósforo de $0,5 \mathrm{~g} \mathrm{~kg}^{-1}$ no tratamento onde o fósforo foi omitido da solução. No tratamento onde todos os nutrientes (inclusive o fósforo) foram fornecidos esse teor foi de $1,7 \mathrm{~g} \mathrm{~kg}^{-1}$.

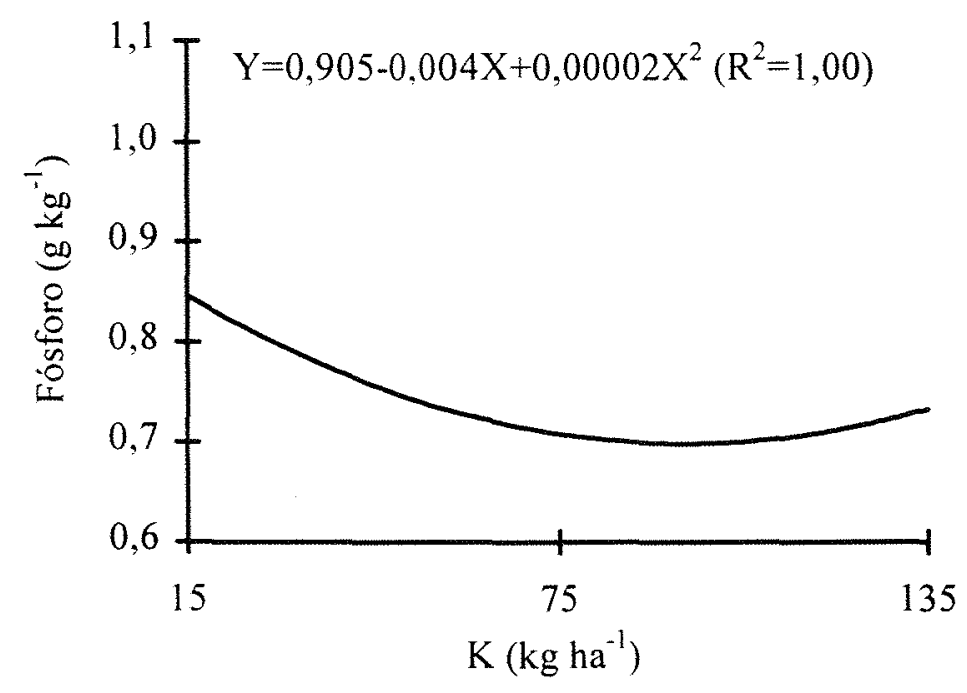

Figura 24. Média da concentração de fósforo na parte aérea dos capins Tifton 85 e Coastcross 1, no segundo crescimento, em função das doses de potássio. 


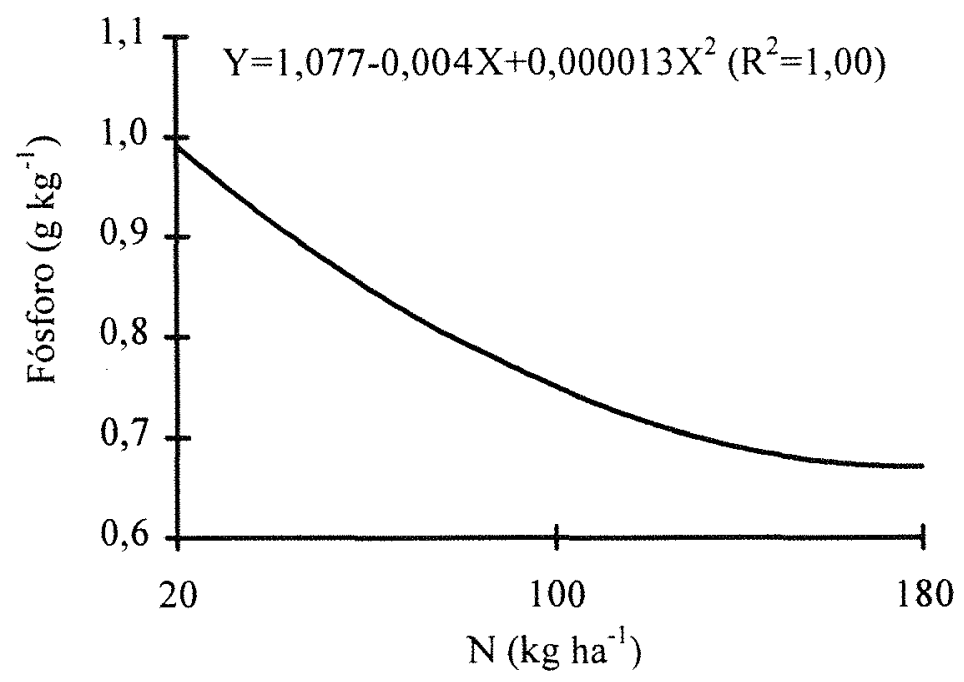

Figura 25. Média da concentração de fósforo na parte aérea dos capins Tifton $85 \mathrm{e}$ Coastcross 1, no terceiro crescimento, em função das doses de nitrogênio.

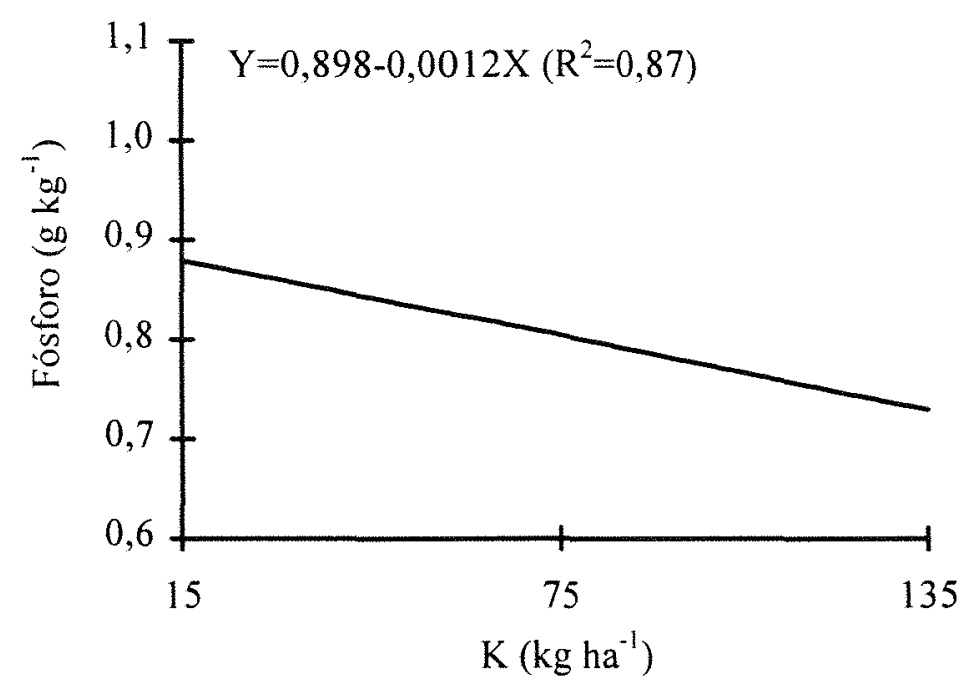

Figura 26. Média da concentração de fósforo na parte aérea dos capins Tifton $85 \mathrm{e}$ Coastcross 1, no terceiro crescimento, em função das doses de potássio. 


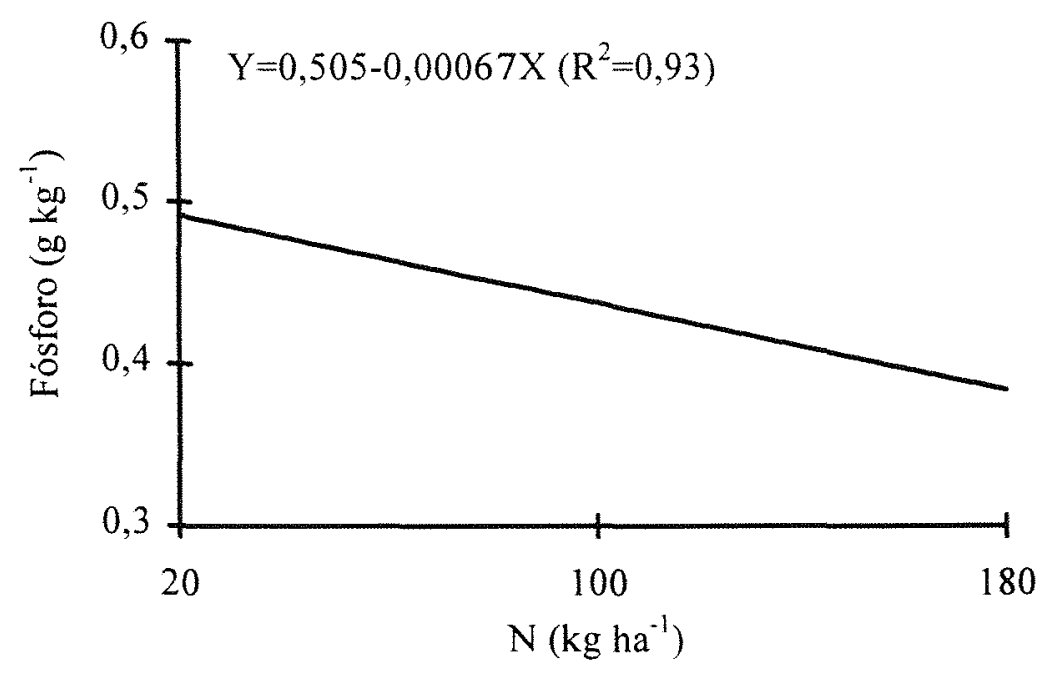

Figura 27. Média da concentração de fósforo nas raízes dos capins Tifton 85 e Coastcross 1 , em função das doses de nitrogênio.

\subsection{Concentração de cálcio nos tecidos vegetais}

Não houve variação significativa $(P>0,05)$ no teor de cálcio na parte aérea entre cultivares ou entre doses de ambos os nutrientes no primeiro periodo de crescimento. No segundo período de crescimento o teor de cálcio foi significativamente maior $(\mathrm{P}<0,05)$ em Coastcross $1\left(3,3 \mathrm{~g} \mathrm{~kg}^{-1}\right)$ do que em Tifton $85\left(3,0 \mathrm{~g} \mathrm{~kg}^{-1}\right)$ e no terceiro crescimento o Tifton 85 apresentou maior teor de cálcio que o Coastcross 1 apenas no tratamento $20 \mathrm{~kg}$ de $\mathrm{N}$ e $75 \mathrm{~kg}$ de $\mathrm{K} \mathrm{ha}^{-1}$ (Tabela 8). Porém o teor de $\mathrm{Ca}$ nas raízes foi maior $(\mathrm{P}<0,05)$ em Tifton $85(1,6 \mathrm{~g}$ $\left.\mathrm{kg}^{-1}\right)$ do que em Coastcross $1\left(1,2 \mathrm{~g} \mathrm{~kg}^{-1}\right)$. Estudos realizados no Brasil com Coastcross 1 mostraram teores de cálcio na parte aérea de $3,0,2,7$ e $2,4 \mathrm{~g} \mathrm{~kg}^{-1}$ (Pedreira e Mattos, 1981; Bufarah et al., 1982; Palhano, 1990).

No terceiro crescimento houve aumento linear $(\mathrm{P}<0,01)$ no teor de cálcio dos capins em função da adubação nitrogenada mas somente no nível $75 \mathrm{~kg}$ de $\mathrm{K}$ 
$\mathrm{ha}^{-1}$ em Coastcross 1 e $135 \mathrm{~kg}$ de $\mathrm{K} \mathrm{ha}^{-1}$ em Tifton 85 (Figura 29), mas decresceu

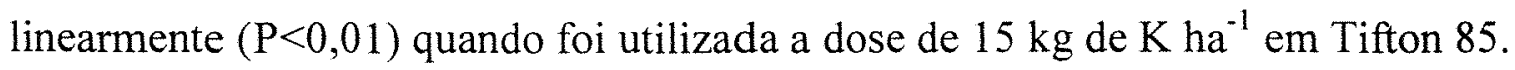

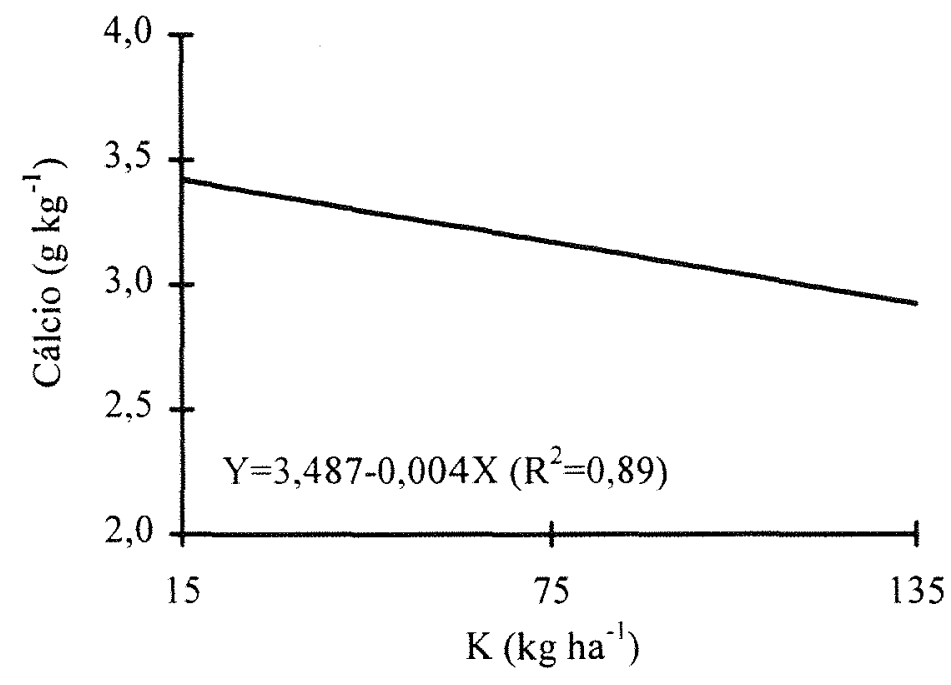

Figura 28. Média da concentração de cálcio na parte aérea dos capins Tifton 85 e Coastcross 1, no segundo crescimento, em função das doses de potássio.

Gonzalez et al. (1983) e Herrera e Hernandez (1985b) verificaram que houve incremento no teor de cálcio em Coastcross 1 com o aumento da adubação nitrogenada. Porém, esses dados não concordam com Caro-Costas et al. (1976), que não observaram variação na concentração de cálcio em capim-estrela quando as adubações com nitrogênio e potássio foram de 270 a $670 \mathrm{~kg} \mathrm{ha}^{-1}$ e de 150 a 370 $\mathrm{kg} \mathrm{ha}^{-1}$, respectivamente.

No segundo e no terceiro corte a concentração de cálcio diminuiu com as doses de potássio (Figura 28 e 29). Esse comportamento foi também mencionado 
por Mesa et al. (1989), Cripps et al. (1989) e Eichhorn e Nelson (1988), em estudos com capins do gênero Cynodon. Nas condições do presente trabalho, o cálcio foi menos absorvido pelos capins quando a dose mais elevada de potássio foi aplicada no solo.

Tabela 8. Concentração de cálcio $\left(\mathrm{g} \mathrm{kg}^{-1}\right)$ na parte aérea dos capins Tifton $85 \mathrm{e}$ Coastcross 1, no terceiro crescimento, em função das doses de nitrogênio e de potássio.

\begin{tabular}{l|c|c|c}
\hline \multirow{2}{*}{ Forrageiras } & \multicolumn{3}{|c}{ Doses $\left(\mathrm{kg} \mathrm{ha}^{-1}\right)$} \\
\cline { 2 - 4 } & $\mathrm{N}=20$ & $\mathrm{~N}=100$ & $\mathrm{~N}=180$ \\
\cline { 2 - 4 } & $5,02 \mathrm{a}=15$ & $4,12 \mathrm{a}$ \\
Tifton 85 & $5,00 \mathrm{a}$ & $4,47 \mathrm{a}$ & $4,62 \mathrm{a}$ \\
\hline & \multicolumn{3}{|c}{$\mathrm{K}=75 \mathrm{a}$} \\
\hline Tifton 85 & $4,42 \mathrm{a}$ & $4,65 \mathrm{a}$ & $4,20 \mathrm{a}$ \\
Coastcross 1 & $3,77 \mathrm{~b}$ & $4,60 \mathrm{a}$ & $4,82 \mathrm{a}$ \\
\hline & \multicolumn{3}{|c}{$\mathrm{K}=135$} \\
\hline Tifton 85 & $3,62 \mathrm{a}$ & $4,35 \mathrm{a}$ & $4,32 \mathrm{a}$ \\
Coastcross 1 & $4,57 \mathrm{a}$ & $3,77 \mathrm{a}$ & $4,67 \mathrm{a}$ \\
\hline Médias seguidas de letras diferentes na mesma subcoluna diferem \\
estatisticamente a 5\% de probabilidade pelo teste de Tukey.
\end{tabular}




\section{TIFTON 85}
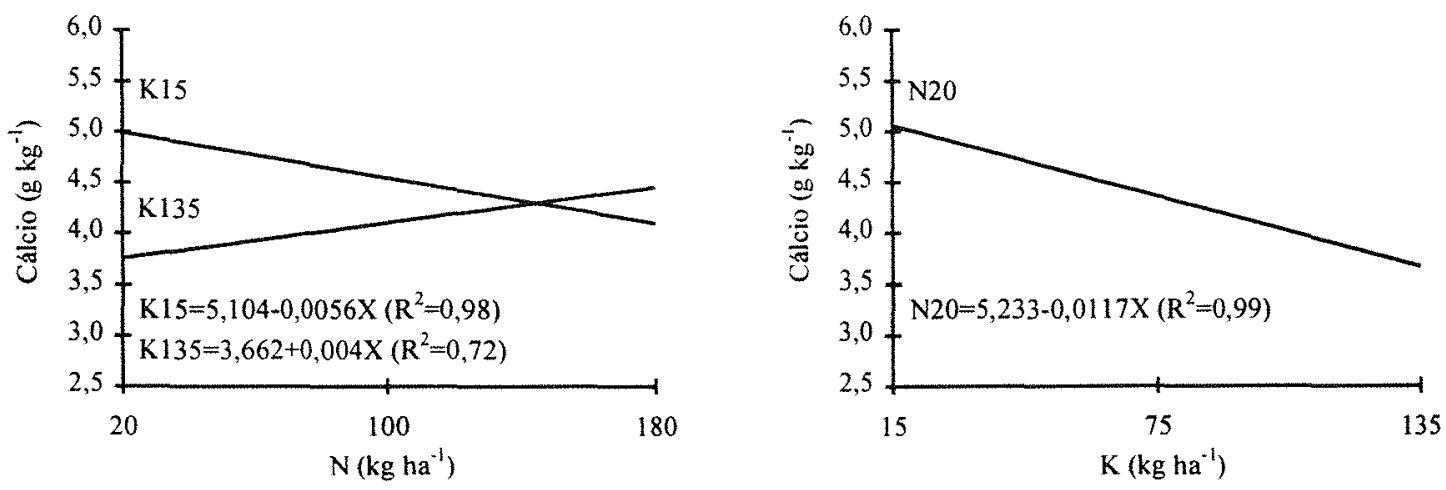

\section{COASTCROSS 1}
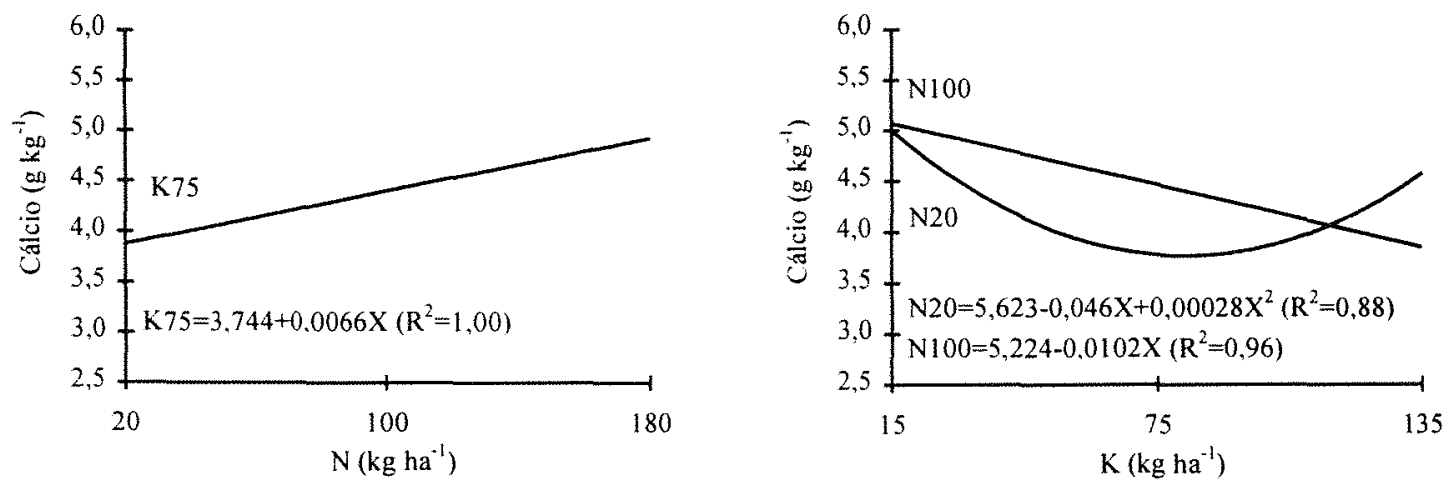

Figura 29. Concentração de cálcio na parte aérea do Tifton 85 e do Coastcross 1 , no terceiro crescimento, em função das doses de nitrogênio e de potássio. 


\subsection{Concentração de magnésio nos tecidos vegetais}

O cultivar Tifton 85 apresentou concentração média de magnésio no primeiro crescimento de $4,7 \mathrm{~g} \mathrm{~kg}^{-1}$, sendo significativamente $(\mathrm{P}<0,05)$ maior do que em Coastcross $1\left(4,1 \mathrm{~g} \mathrm{~kg}^{-1}\right)$. Em todos os períodos de crescimento, esses capins apresentaram teor de magnésio superior a $3,0 \mathrm{~g} \mathrm{~kg}^{-1}$, com exceção ao nível $135 \mathrm{~kg} \mathrm{de} \mathrm{K} \mathrm{ha}^{-1}$, na dose mais baixa de nitrogênio no terceiro corte (Figura 33). Em Coastcross 1, Palhano (1990) encontrou teor de magnésio de $3,8 \mathrm{~g} \mathrm{~kg}^{-1}$ aos 30 dias de crescimento. Com a mesma idade de corte, Gomide et al. (1969) observaram que o teor de magnésio em Swannee foi de $3,1 \mathrm{~g} \mathrm{~kg}^{-1}$. Esses valores foram superiores ao valor médio de $2,3 \mathrm{~g} \mathrm{~kg}^{-1}$ obtido por Gallo et al. (1974) em pastagens de Cynodon dactylon no Estado de São Paulo.

No segundo e terceiro crescimentos o teor de magnésio aumentou linearmente $(\mathrm{P}<0,01)$ com o incremento nas doses de nitrogênio, mas apenas para os níveis mais elevados de potássio ( 75 e $135 \mathrm{~kg}$ de $\left.\mathrm{K} \mathrm{ha}^{-1}\right)$, no terceiro crescimento (Figura 33). O aumento no teor de magnésio com a adubação nitrogenada também foi verificado por Gonzalez et al. (1983) e Herrera e Hernandez (1985b) em estudos com o Coastcross 1. 


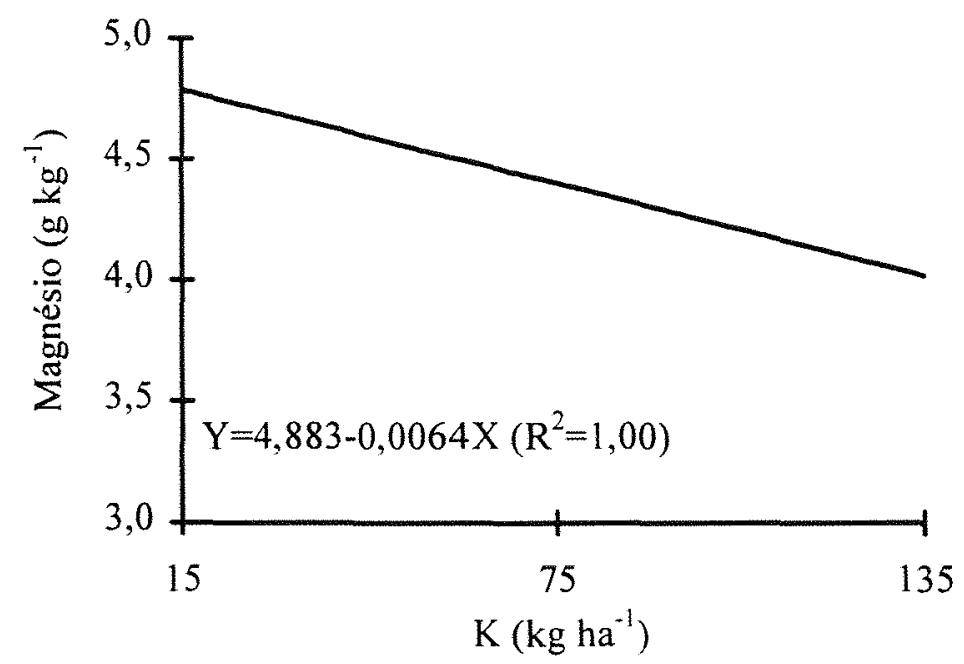

Figura 30. Média da concentração de magnésio na parte aérea dos capins Tifton 85 e Coastcross 1, no primeiro crescimento, em função das doses de potássio.

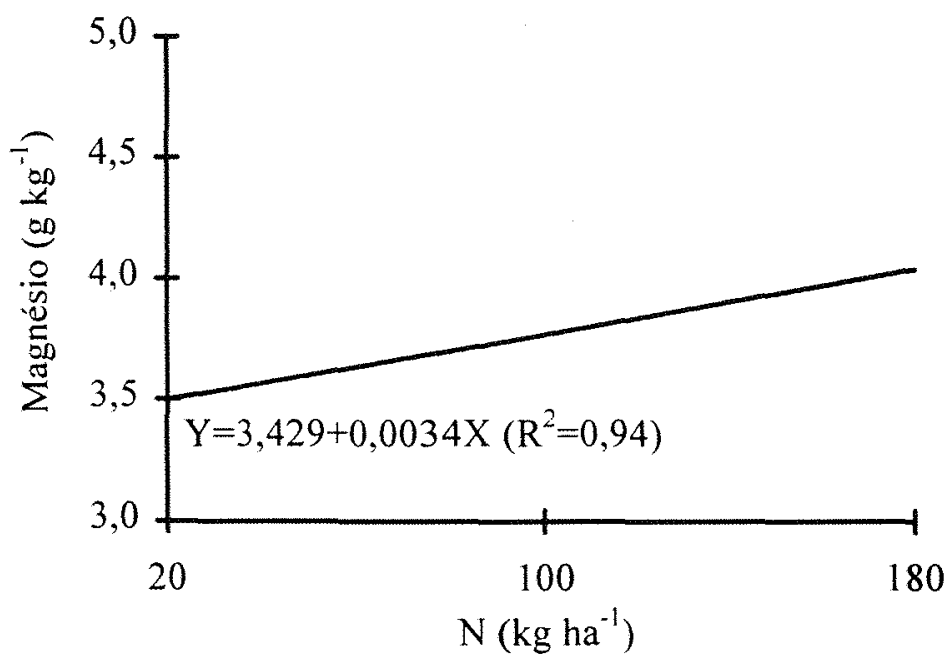

Figura 31. Média da concentração de magnésio na parte aérea dos capins Tifton 85 e Coastcross 1, no segundo crescimento, em função das doses de nitrogênio. 


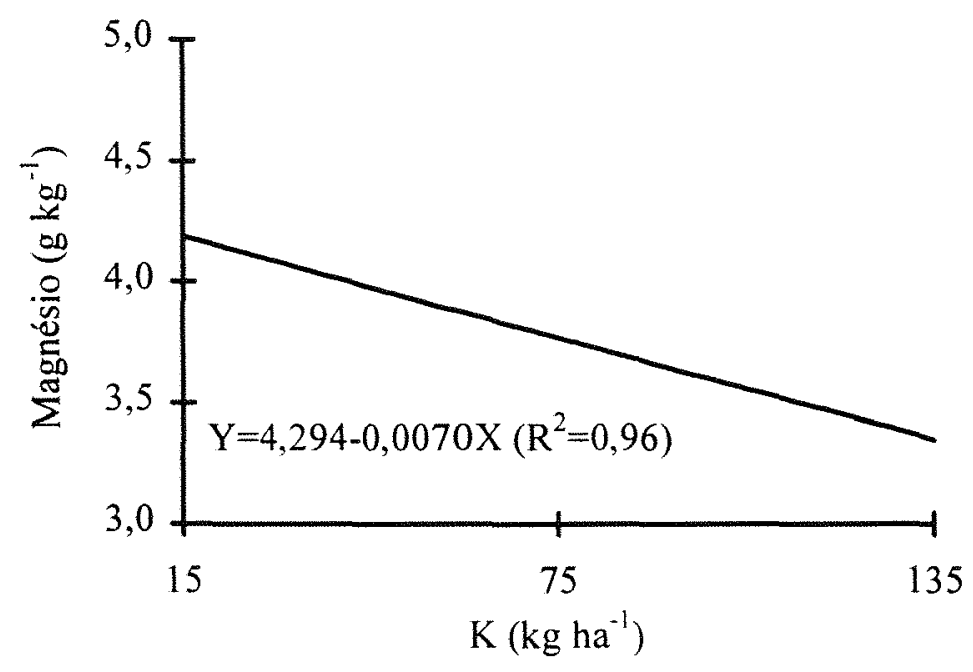

Figura 32. Média da concentração de magnésio na parte aérea dos capins Tifton 85 e Coastcross 1, no segundo crescimento, em função das doses de potássio.
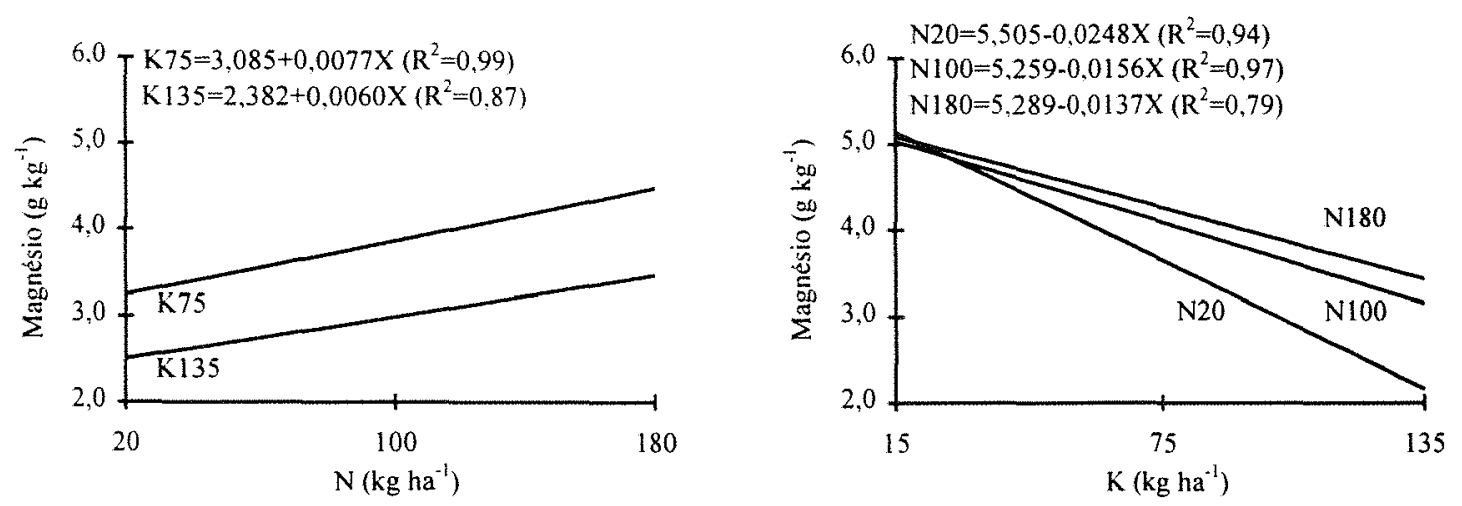

Figura 33. Concentração de magnésio na parte aérea do Tifton 85 e do Coastcross 1, no terceiro crescimento, em função das doses de nitrogênio e de potássio. 
No material vegetal de todos os cortes o teor de magnésio foi significativamente influenciado pela adubação potássica. No primeiro e no segundo crescimento, o teor de magnésio decresceu linearmente $(\mathrm{P}<0,01)$ com a adubação potássica (Figura 30 e 32), porém esse decréscimo foi mais acentuado no terceiro crescimento (Figura 33). Em Coastal, o teor de magnésio diminuiu de 2,3 para $1,7 \mathrm{~g} \mathrm{~kg}^{-1}$ com o aumento da adubação potássica de 0 para $560 \mathrm{~kg}$ de $\mathrm{K} \mathrm{ha}^{-1}$ (Eichhorn e Nelson, 1988). Silva et al. (1995) também observaram decréscimo significativo no teor de magnésio na parte aérea do Tanzânia em função de doses de potássio na solução nutritiva.

Malavolta (1981) preconizou que a relação potássio:magnésio no solo é importante, uma vez que o excesso do primeiro causa menor absorção do segundo pelas plantas. No entanto, mais estudos são necessários a fim de verificar se a queda no teor de cálcio e magnésio em função das doses de potássio chegaram a se tornar limitantes para desenvolvimento desses capins.

$\mathrm{Na}$ raizes o teor magnésio diminuiu $(\mathrm{P}<0,01)$ em função das doses de nitrogênio (Figura 34). Não foi observada variação significativa $(\mathrm{P}>0,05)$ para o teor de magnésio nas raízes em função das doses de potássio. Também verificouse que o teor de magnésio foi maior $(\mathrm{P}<0,05)$ em Tifton $85\left(0,5 \mathrm{~g} \mathrm{~kg}^{-1}\right)$ do que em Coastcross $1\left(0,4 \mathrm{~g} \mathrm{~kg}^{-1}\right)$. Monteiro et al. (1995) observaram que o teor de magnésio em raízes de Brachiaria brizantha cv. Marandu, cultivada em solução nutritiva, foi de $0,3 \mathrm{~g} \mathrm{~kg}^{-1}$ no tratamento onde todos os nutrientes foram fornecidos na solução. 


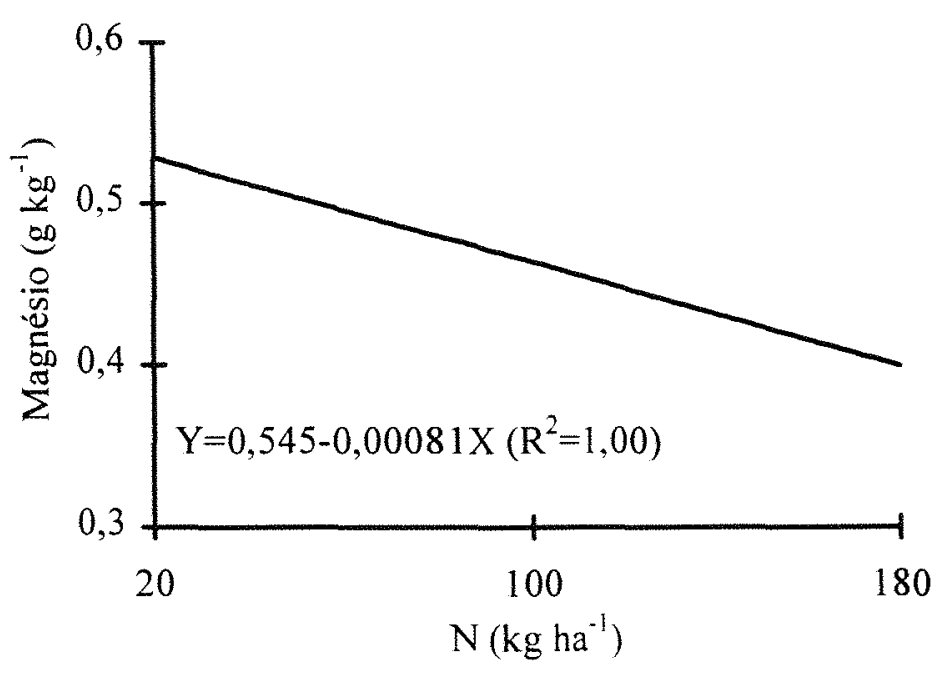

Figura 34. Média da concentração de magnésio nas raízes dos capins Tifton 85 e Coastcross 1 , em função das doses de nitrogênio.

\subsection{Concentração de FDN e FDA}

O teor de fibra em detergente neutro (FDN) decresceu em função da adubação nitrogenada no primeiro e segundo crescimentos, em ambos cultivares (Figuras 35 e 36), e no terceiro crescimento apenas em Coastcross 1 (Figura 37). O mesmo comportamento foi verificado por Ferrari Júnior et al. (1993), que obtiveram teor de FDN de 766,8 e 760,5 $\mathrm{g} \mathrm{kg}^{-1}$ em Coastcross 1 sem adubação e com adubação de reposição de $2 \%$ de $\mathrm{N}$ e $4 \%$ de $\mathrm{KCl}$ (com base na matéria seca removida), respectivamente. Alvim et al. (1996) também observaram que o teor de FDN em Coastcross 1 decresceu de 710 para $610 \mathrm{~g} \mathrm{~kg}^{-1}$ quando a adubação nitrogenada aumentou de 0 para $750 \mathrm{~kg}_{\text {de }} \mathrm{N} \mathrm{ha}^{-1} \mathrm{ano}^{-1}$. 


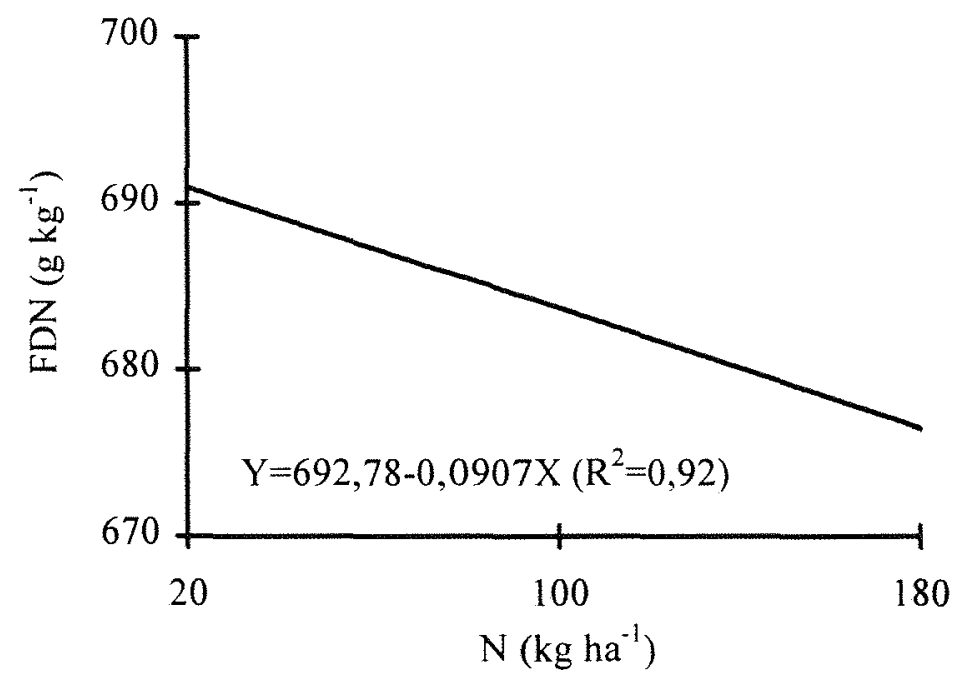

Figura 35. Média dos teores de FDN dos capins Tifton 85 e Coastcross 1 , no primeiro crescimento, em função das doses de nitrogênio.

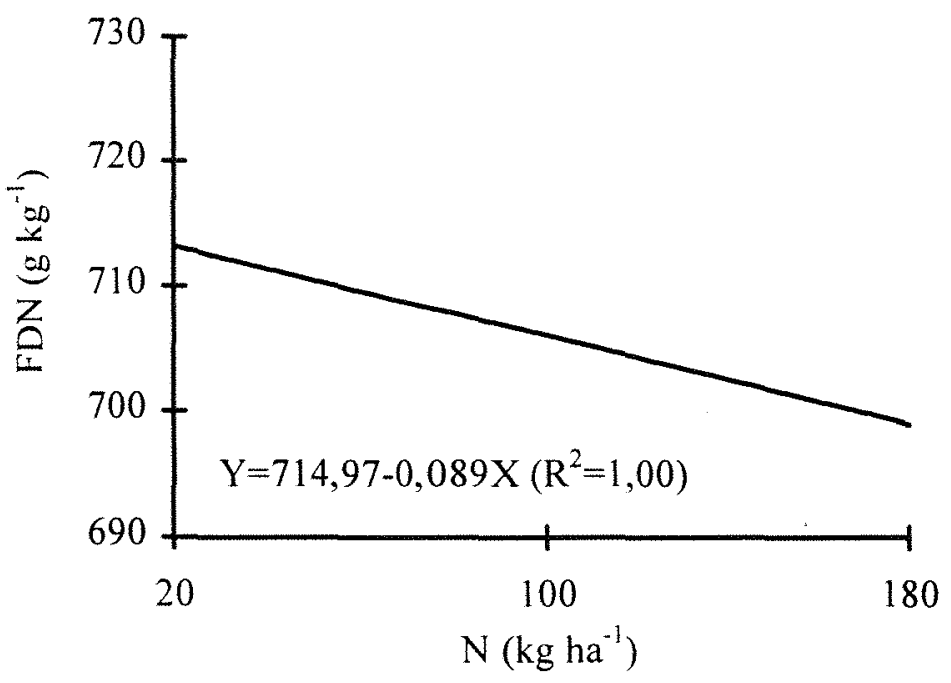

Figura 36. Média dos teores de FDN dos capins Tifton 85 e Coastcross 1, no segundo crescimento, em função das doses de nitrogênio. 


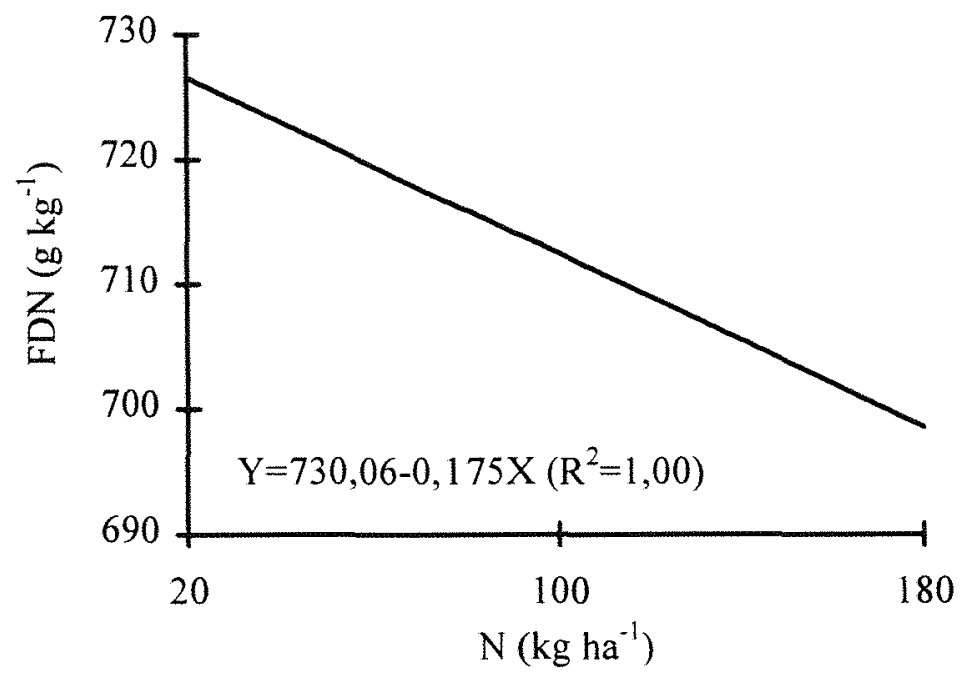

Figura 37. Concentração de FDN do Coastcross 1, no terceiro crescimento, em função das doses de nitrogênio.

No segundo crescimento o teor de FDN foi maior $(\mathrm{P}<0,05)$ em Tifton 85 $\left(711,6 \mathrm{~g} \mathrm{~kg}^{-1}\right)$ do que em Coastcross $1\left(700,6 \mathrm{~g} \mathrm{~kg}^{-1}\right)$. O teor de FDN em Tifton 85 não variou no terceiro corte com as doses de nitrogênio, e foi maior $(\mathrm{P}<0,05)$ em Tifton 85 do que em Coastcross 1 apenas no tratamento $180 \mathrm{~kg} \mathrm{de} \mathrm{N} \mathrm{ha}^{-1}$ (Figura 38). Em estudos com o Tifton 85, Hill et al. (1993) e Pedreira (1995), obtiveram valores de FDN de 730 e $808 \mathrm{~g} \mathrm{~kg}^{-1}$, respectivamente.

Em Coastcross 1 com 30 dias de crescimento, Palhano (1990) obteve teor de FDN de $716 \mathrm{~g} \mathrm{~kg}^{-1}$, valor esse semelhante ao obtido no presente estudo, porém superior ao relatado por Ferrari Júnior et al. (1993) que encontraram em folhas de Coastcross 1 teor de FDN de $694 \mathrm{~g} \mathrm{~kg}^{-1}$ em pastagem onde foi feita adubação de reposição com nitrogênio e potássio.

Eichhorn e Nelson (1988) observaram que a concentração de FDN em Coastal decresceu $(\mathrm{P}<0,05)$ com o aumento da adubação potássica. No entanto, 
não foi observado nesse experimento variação significativa no teor de FDN no Coastcross 1 e no Tifton 85 em função das doses de potássio.

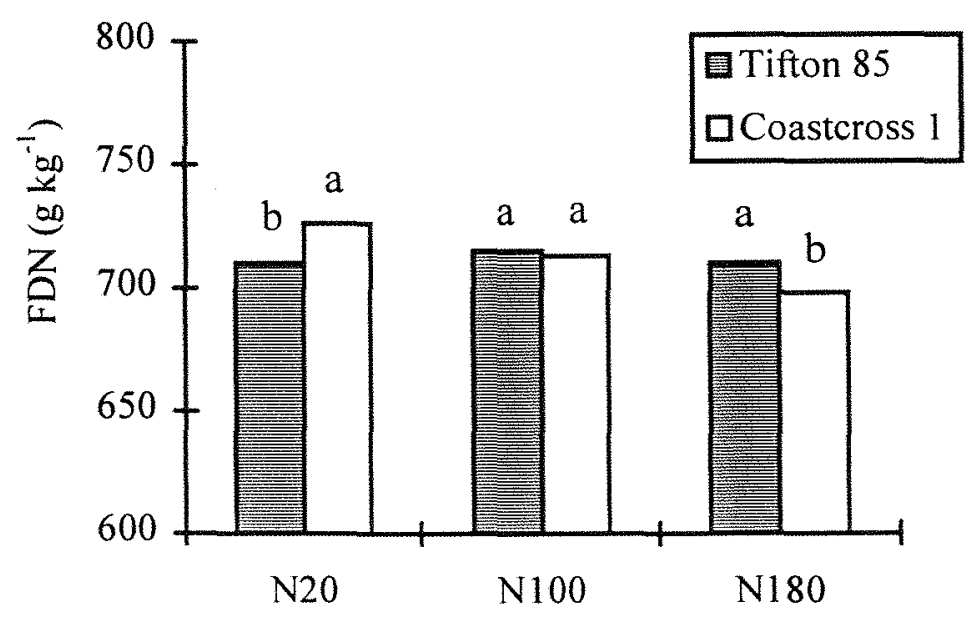

Figura 38. Concentração de FDN ( $\mathrm{g} \mathrm{kg}^{-1}$ ) nos capins Tifton 85 e Coastcross 1 , no terceiro crescimento, em função das doses de nitrogênio (médias seguidas de letras diferentes dentro da mesma dose de nitrogênio diferem estatisticamente a $5 \%$ de probabilidade pelo teste de Tukey).

O teor de fibra em detergente ácido (FDA) encontrado para Tifton 85 foi de $322,8 \mathrm{~g} \mathrm{~kg}^{-1}$ no primeiro corte, sendo menor $(\mathrm{P}<0,05)$ do que o encontrado em Coastcross $1\left(335,5 \mathrm{~g} \mathrm{~kg}^{-1}\right)$. No segundo e terceiro cortes, o valor de FDA obtido em Tifton 85 foi de 373,8 e $373,3 \mathrm{~g} \mathrm{~kg}^{-1}$, e foi maior $(\mathrm{P}<0,05)$ do que o obtido em Coastcross 1 que foi de 364,6 e $360,4 \mathrm{~g} \mathrm{~kg}^{-1}$, respectivamente. Teor de FDA (379 $\mathrm{g} \mathrm{kg}^{-1}$ ) mais elevado do que o do presente estudo foi obtido por Palhano (1990), em experimento com Coastcross 1 para intervalo entre cortes de 30 dias, adubado com $250 \mathrm{~kg}$ de $\mathrm{N}$ e $250 \mathrm{~kg}$ de $\mathrm{K} \mathrm{ha}^{-1}$. Esses valores foram superiores ao obtido por Utley et al. (1971) em estudos com o Coastcross 1 e o Coastal, adubados com 45 $\mathrm{kg}$ de $\mathrm{N} \mathrm{ha}^{-1}$ corte $^{-1}$ e cortados a cada 28 dias. 
No primeiro crescimento não houve variação significativa de FDA em função da adubação. Porém, no segundo e terceiro crescimentos o teor de FDA decresceu com o incremento das doses de nitrogênio (Figura 39 e 40), apresentando comportamento semelhante ao teor de FDN desses capins. Esses dados não concordam com Reid et al. (1967a), os quais não observaram correlação entre a adubação nitrogenada e o teor de FDA em Orchardgrass.

Nesse estudo não foi observada variação significativa $(\mathrm{P}>0,05)$ no teor de FDA em função das doses de potássio, ao contrário do obtido por Eichhorn e Nelson (1988), que observaram decréscimo ( $\mathrm{P}<0,01)$ no teor de FDA de Coastal bermuda de 334 para $323 \mathrm{~g} \mathrm{~kg}^{-1}$ com o aumento da adubação potássica de 0 para $560 \mathrm{~kg}^{\mathrm{de} \mathrm{K} \mathrm{ha}^{-1}}$ ano $^{-1}$.

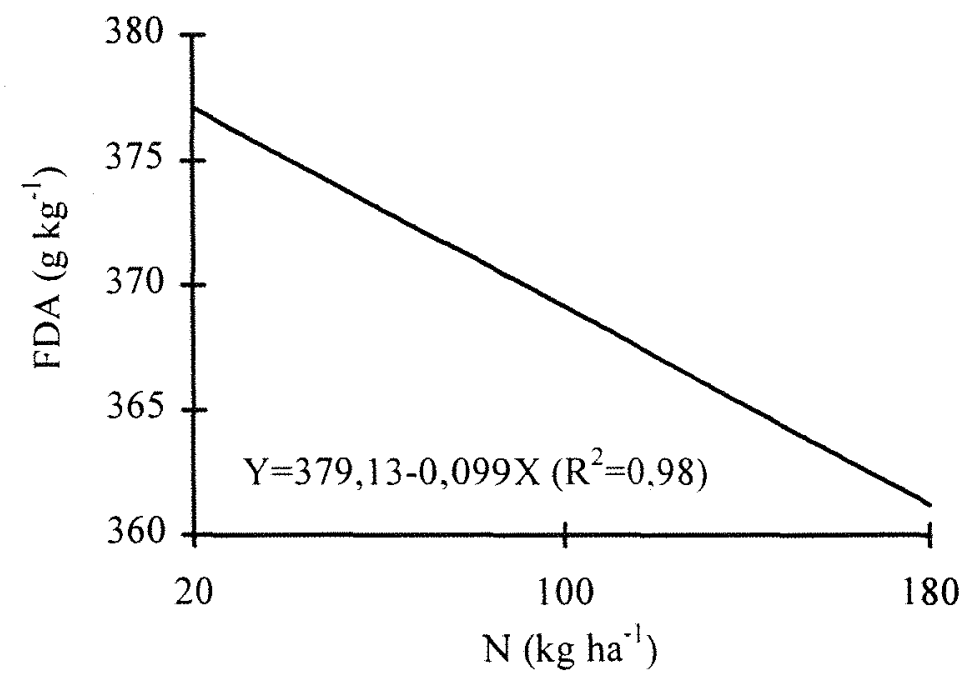

Figura 39. Média dos teores de FDA dos capins Tifton 85 e Coastcross 1 , no segundo crescimento, em função das doses de nitrogênio. 


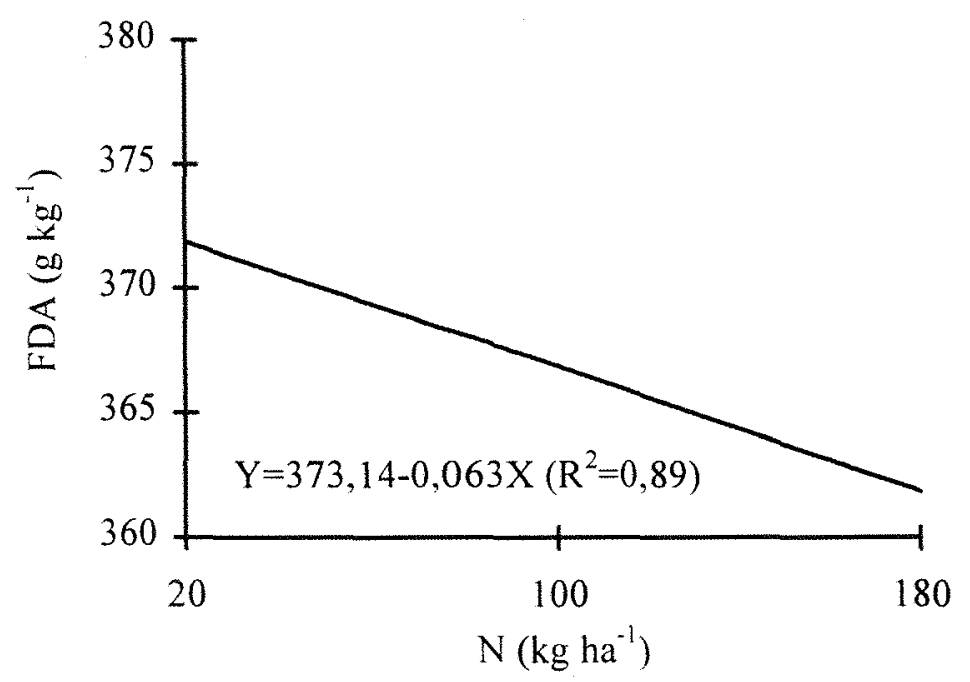

Figura 40. Média dos teores de FDA dos capins Tifton 85 e Coastcross 1, no terceiro crescimento, em função das doses de nitrogênio.

\subsection{Digestibilidade in vitro da matéria seca}

O Tifton 85 apresentou consistentemente DIVMS superior $(\mathrm{P}<0,05)$ ao Coastcross 1 no primeiro crescimento, para as doses de nitrogênio (Figura 41). O mesmo foi observado no segundo e terceiro cortes onde a DIVMS do Tifton 85 $\left(649,9\right.$ e $650,4 \mathrm{~g} \mathrm{~kg}^{-1}$, respectivamente) foi maior $(\mathrm{P}<0,05)$ do que o Coastcross 1 $\left(610,7\right.$ e $620,7 \mathrm{~g} \mathrm{~kg}^{-1}$, respectivamente). O Tifton 85 também se mostrou superior em um experimento realizado por Hill et al. (1993), onde apresentou maior DIVMS (596 $\mathrm{g} \mathrm{kg}^{-1}$ ) do que o Tifton 78 (559 $\left.\mathrm{g} \mathrm{kg}^{-1}\right)$. Pedreira (1995) observou maior DIVMO no Tifton $85\left(554 \mathrm{~g} \mathrm{~kg}^{-1}\right)$ do que em Florakirk $\left(534 \mathrm{~g} \mathrm{~kg}^{-1}\right)$. Os valores de DIVMS para o Tifton 85 nesse estudo foram superiores aos apresentados na literatura e tal resultado pode ter sido influenciado por fatores ambientais reinantes nas condições experimentais. 
A DIVMS encontrada em Coastcross 1 nos três períodos de crescimento foi superior a DIVMS obtida em Coastcross 1 por Beltran e Santa Cruz (1985) que foi de $581 \mathrm{~g} \mathrm{~kg}^{-1}$ utilizando uma adubação com $100 \mathrm{~kg} \mathrm{de} \mathrm{N} \mathrm{ha}^{-1} \mathrm{ano}^{-1}$ e por Alcântara et al. (1981) que obtiveram $378 \mathrm{~g} \mathrm{~kg}^{-1}$ em capim adubado com $200 \mathrm{~kg}$ de $\mathrm{N} \mathrm{ha}^{-1}$ ano $^{-1}$ e cortado com 60 dias de crescimento.

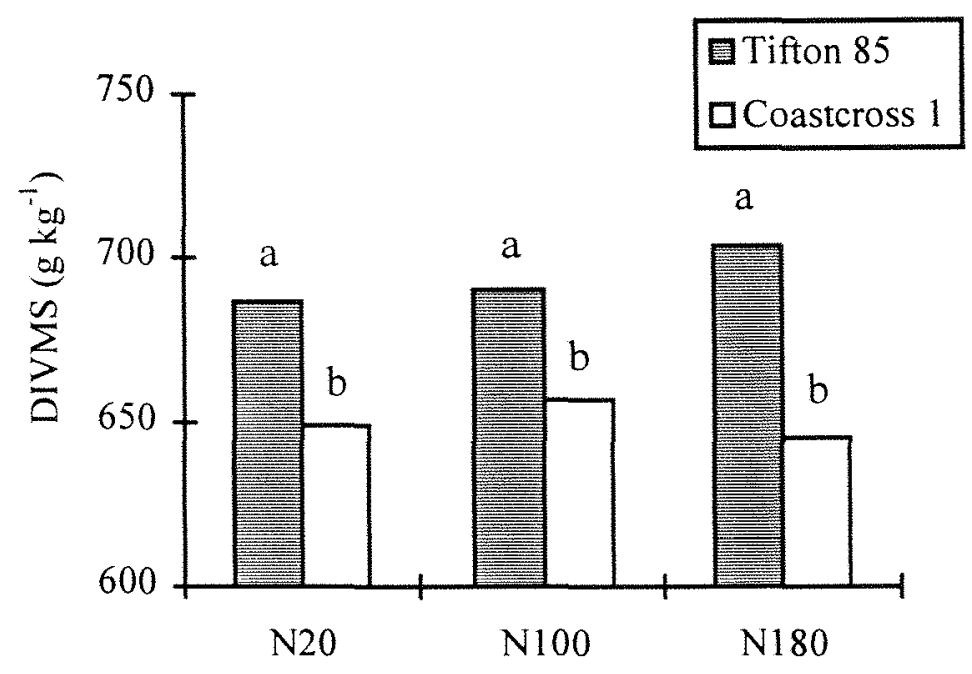

Figura 41. Coeficiente de DIVMS $\left(\mathrm{g} \mathrm{kg}^{-1}\right)$ dos capins Tifton 85 e do Coastcross 1 , no primeiro crescimento, em função das doses de nitrogênio (médias seguidas de letras diferentes dentro da mesma dose de nitrogênio diferem estatisticamente a $5 \%$ de probabilidade pelo teste de Tukey).

Em estudos com o Coastcross 1 cortado a cada três semanas e adubado com $200 \mathrm{~kg}$ de $\mathrm{N} \mathrm{ha}^{-1}$ ano $^{-1}$, foi obtido coeficiente de DIVMS de 723 e $690 \mathrm{~g} \mathrm{~kg}^{-1}$ (Duble et al., 1971 e Gutierrez et al., 1980). Palhano (1990) observou DIVMS em Coastcross 1 de $690 \mathrm{~g} \mathrm{~kg}^{-1}$ cortado a cada quatro semanas e adubado com $250 \mathrm{~kg}$ de $\mathrm{Nha}^{-1}$ ano $^{-1}$. 
No primeiro crescimento foi verificada interação significativa entre adubação nitrogenada e cultivares, sendo que houve aumento $(\mathrm{P}<0,05)$ da DIVMS com a adubação nitrogenada em Tifton 85 , mas o mesmo não foi observado em Coastcross 1 (Figura 42).

No segundo corte observou-se que tanto a adubação nitrogenada como a potássica induziram a um aumento da DIVMS dos capins (Figuras 43 e 44). Já no terceiro crescimento não houve efeito significativo $(P>0,05)$ na digestibilidade dos capins com as doses de nitrogênio e de potássio.

A DIVMS incrementou de 685 para $702 \mathrm{~g} \mathrm{~kg}^{-1}$ entre a mais baixa e a mais elevada dose de nitrogênio em Tifton 85 no primeiro crescimento e de 624 para $637 \mathrm{~g} \mathrm{~kg}^{-1}$ na média de ambos capins no segundo crescimento. $\mathrm{O}$ aumento da DIVMS com a adubação nitrogenada foi mencionado por Waite (1970) e Blaser (1964), mas discorda do relato de Van Soest (1994).

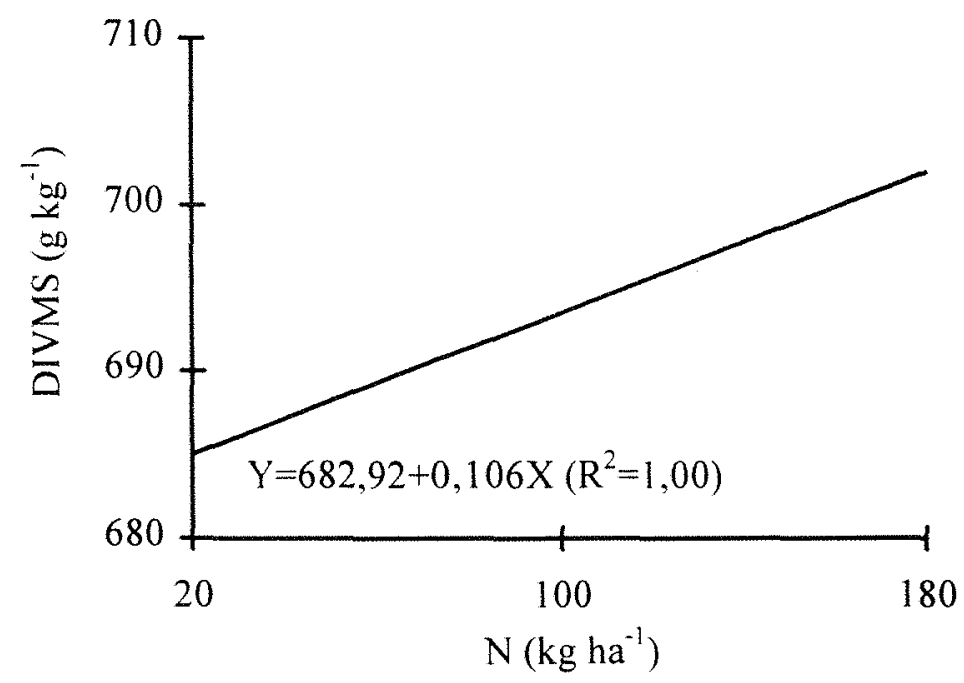

Figura 42. Coeficiente de DIVMS do Tifton 85 , no primeiro crescimento, em função das doses de nitrogênio. 


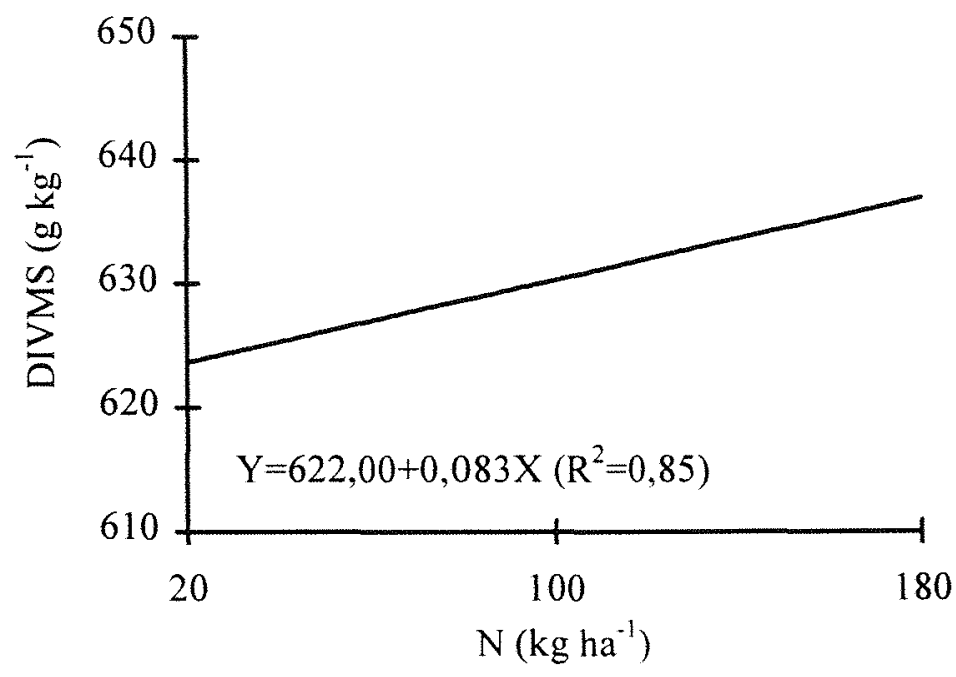

Figura 43. Média do coeficiente de DIVMS dos capins Tifton 85 e Coastcross 1, no segundo crescimento, em função das doses de nitrogênio.

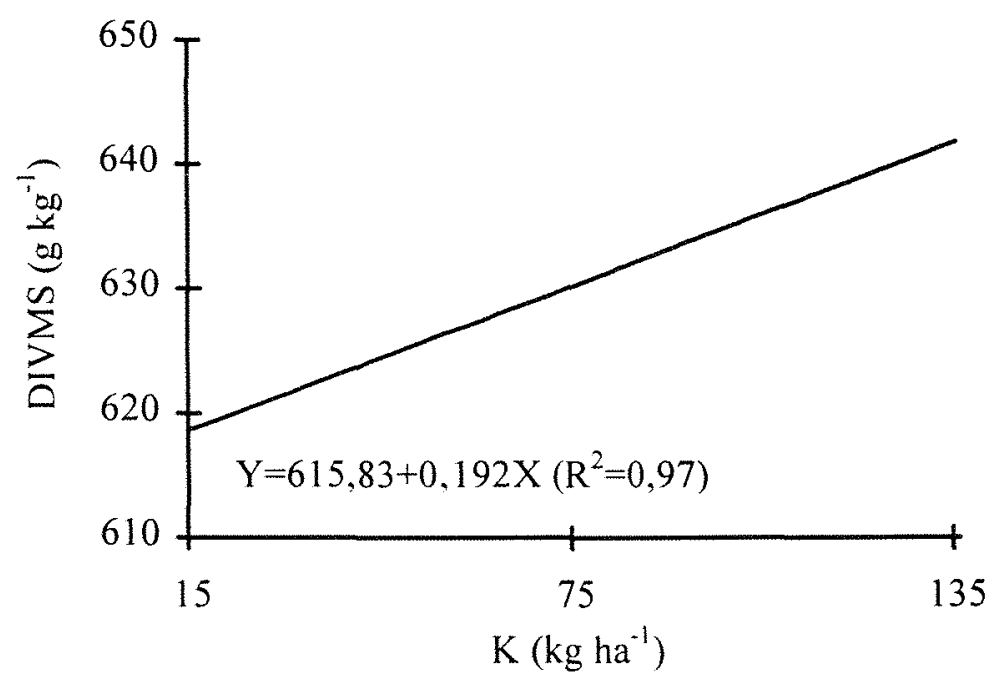

Figura 44. Média do coeficiente de DIVMS dos capins Tifton 85 e Coastcross 1 , no segundo crescimento, em função das doses de potássio. 
Os dados na literatura são conflitantes com relação à variação na digestibilidade com a adubação nitrogenada. Woefel e Poulton (1960) obtiveram redução de $31 \mathrm{~g} \mathrm{~kg}^{-1}$ na DIVMS de feno de timothy (Phleum pratense) com o aumento da adubação de 0 para $250 \mathrm{~kg}$ de $\mathrm{N} \mathrm{ha}^{-1} \mathrm{ano}^{-1}$. Coto et al. (1990) e Cáceres et al. (1989) não observaram variação na digestibilidade de Coastcross 1 com adubações nitrogenadas variando de 0 até $400 \mathrm{~kg} \mathrm{de} \mathrm{N} \mathrm{ha}^{-1} \mathrm{ano}^{-1}$. Por outro lado, Monson e Burton (1982) e Herrera et al. (1985) obtiveram aumento significativo $(\mathrm{P}<0,05)$ na digestibilidade em diversas espécies e híbridos de Cynodon com a elevação na adubação nitrogenada.

A variação na DIVMS do Coastcross 1 e do Tifton 85 no segundo corte foi de $26 \mathrm{~g} \mathrm{~kg}^{-1}$ da mais baixa para a mais elevada dose de potássio, sendo essa variação maior do que a obtida com as doses nitrogênio. Essa variação, no entanto, foi significativa apenas no segundo crescimento dos capins. De forma semelhante, Eichhorn e Nelson (1988), observaram aumento no coeficiente de digestibilidade do Coastal bermuda com a adubação potássica, porém esse aumento não foi estatisticamente significativo $(\mathrm{P}>0,05)$.

Os resultados do presente estudo mostram que houve uma diminuição no teor de fibras nos capins e aumento da digestibilidade com a adubação nitrogenada. Tal fato concorda com Nascimento e Pinheiro (1975) que relataram que o aumento no teor de fibras de um capim induz a um decréscimo na digestibilidade do mesmo. Por outro lado, os resultados desse estudo também mostraram que o Tifton 85, apesar de ter revelado maior teor de FDA e FDN, foi também mais digestível que o Coastcross 1 . 


\subsection{Concentração de nutrientes e saturação por bases do solo}

$\mathrm{O}$ pH do solo antes e após a calagem foi de 4,70 e 5,30, respectivamente e não variou significativamente $(P>0,05)$ com os fatores estudados. No entanto, a porcentagem de saturação por bases ao final do experimento diminuiu linearmente $(\mathrm{P}<0,01)$ em função das doses de nitrogênio aplicadas no solo (Figura 45).

Esse solo apresentou V\% muito baixo antes da calagem (5,5\%) e, apesar de ter-se utilizado $60 \%$ para o cálculo da necessidade de calagem (método da saturação por bases), o valor atingido após o período de incubação foi de $48,7 \%$. Cruz et al. (1994) recomendaram que a saturação por bases do solo seja elevada quando esta apresentar-se inferior a $50 \%$ em braquiária brizanta e andropogon.

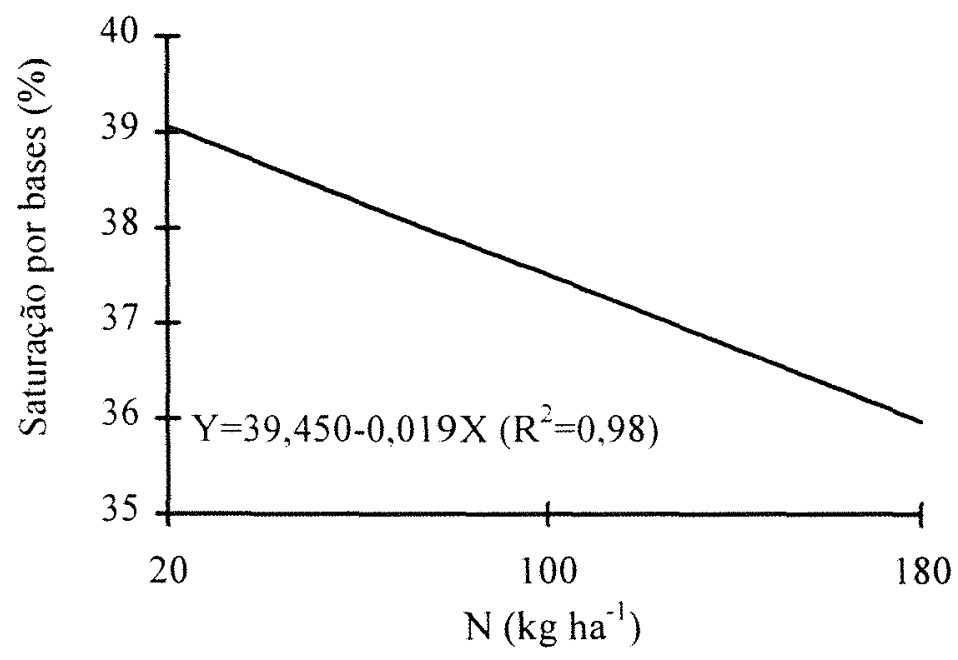

Figura 45. Saturação por bases do solo após o término do experimento, em função das doses de nitrogênio.

No final do experimento, mesmo para a dose mais baixa de nitrogênio, a porcentagem de saturação por bases mostrou-se mais baixa em um período envolvendo três cortes. Dessa forma mais estudos são necessários a fim de 
verificar a melhor recomendação de calagem nesse tipo de solo, para esses capins, com dosagens elevadas de nitrogênio.

A concentração de magnésio no solo ao final de todo o período experimental também variou com a adubação nitrogenada. Na Figura 46 pode-se observar decréscimo linear $(\mathrm{P}<0,01)$ com a adubação nitrogenada e isso pode ter sido conseqüência de maior extração do nutriente pela maior produção dessas forrageiras sob essa adubação. Adams et al. (1967), em estudos com o Coastal bermuda, verificaram que o teor de $\mathrm{Ca}$ e de $\mathrm{Mg}$ trocáveis no solo decresceram significativamente em função da adubação nitrogenada de 0 até $1793 \mathrm{~kg}$ de $\mathrm{N} \mathrm{ha}^{-1}$, no tratamento onde o calcário não havia sido aplicado.

Já a concentração de potássio no solo sofreu interferência das adubações nitrogenada e potássica. A Figura 47 mostra que nos dois níveis mais baixos de

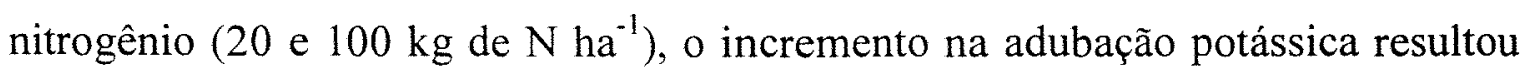
em aumento no teor de potássio trocável no solo. Porém, quanto mais elevada dose de nitrogênio, mais baixo o teor de potássio trocável no solo, mesmo para a dose mais elevada de potássio na adubação (135 $\mathrm{kg}_{\text {de } \mathrm{K} \mathrm{ha}}{ }^{-1}$ ). Cripps et al. (1989) observaram aumento significativo no teor de potássio trocável do solo quando a adubação foi de 0 para $140 \mathrm{~kg}$ de $\mathrm{K} \mathrm{ha}^{-1} \mathrm{ano}^{-1}$ e $140 \mathrm{~kg}$ de $\mathrm{N} \mathrm{ha}^{-1}$ por corte (aplicados quatro a cinco vezes por ano). 


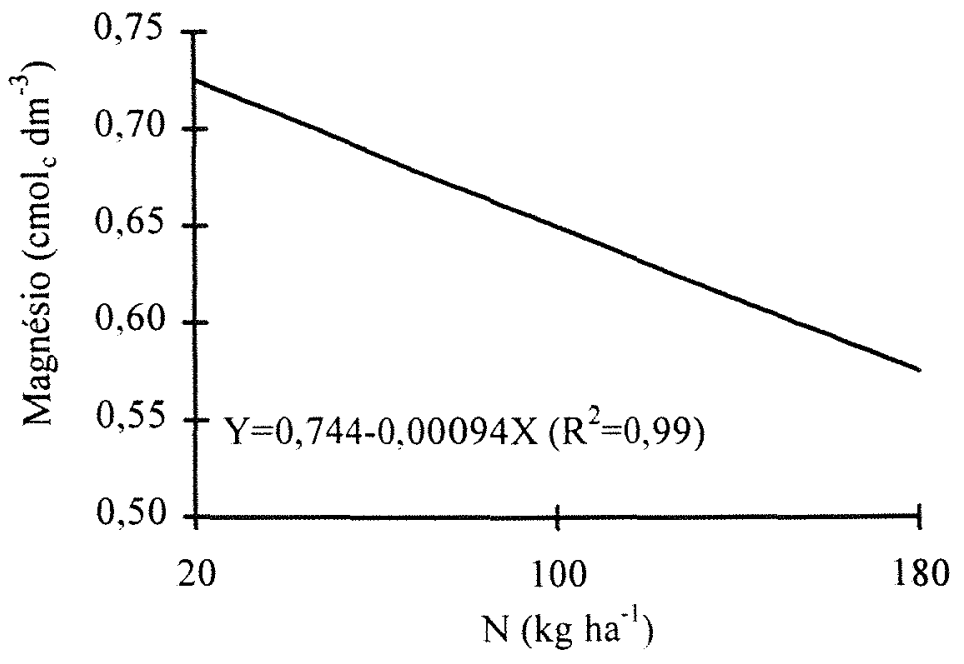

Figura 46. Concentração de magnésio trocável no solo após o término do experimento, em função das doses de nitrogênio.
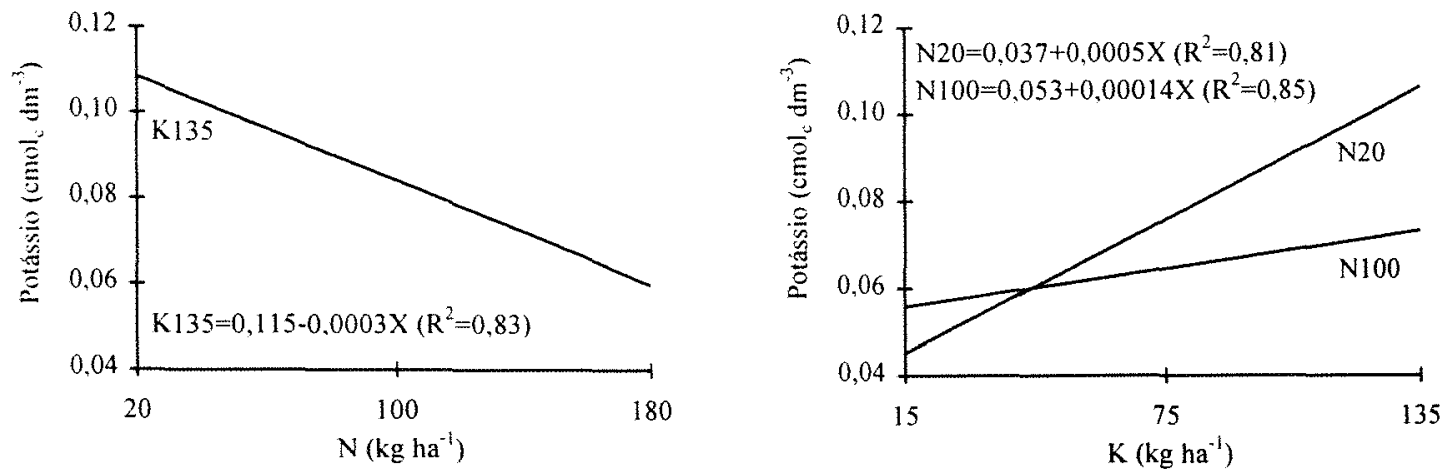

Figura 47. Concentração de potássio trocável no solo após o término do experimento, em função das doses de nitrogênio e de potássio. 


\section{CONCLUSÕES}

- A adubação nitrogenada proporcionou aumento linear na produção de matéria seca da parte aérea do Tifton 85 e do Coastcross 1 , em três períodos de crescimento.

- A produção de matéria seca da parte aérea dos dois capins foi incrementada pelas doses de potássio no segundo e terceiro cortes, quando foram empregadas as doses mais elevadas de nitrogênio.

- Não houve diferença entre os capins Coastcross 1 e Tifton 85 na produção de matéria seca da parte aérea.

- A produção de matéria seca das raízes foi incrementada nessas forrageiras pela aplicação das maiores doses de nitrogênio, somente na presença das mais elevadas doses de potássio.

- A relação haste:lâmina foi mais elevada em Coastcross 1 do que em Tifton 85, e foi diminuída pela adubação nitrogenada e aumentada pela aplicação de potássio.

- As concentrações de nitrogênio e de magnésio na parte aérea foram incrementadas pela aplicação de nitrogênio e diminuídas pela adubação potássica, enquanto a concentração de potássio sofreu aumento com as doses de potássio e decréscimo com as de nitrogênio.

- O teor de FDA e de FDN dos capins não variou em função das doses de potássio, porém diminuiu em função das doses de nitrogênio e foi normalmente mais elevado em Tifton 85 do que em Coastcross 1. 


\section{REFERÊNCIAS BIBLIOGRÁFICAS}

ABREU, J.B.R. Níveis de nitrogênio e proporções de nitrato e amônio afetando produção, atividade da redutase do nitrato e composição de três gramíneas forrageiras. Piracicaba, 1994. 103p. Dissertação (Mestrado) - Escola Superior de Agricultura "Luiz de Queiroz", Universidade de São Paulo.

ADAMS, W.E.; WHITE, A.W.; McCREERY, R.A.; DAWSON, R.N. Coastal bermudagrass forage produtition and chemical composition as influenced by potassium rate and frequency of aplication. Agronomy Journal, v.59, n.3, p.247-250, 1967.

ADAMS, W.E.; PEARSON, R.W.; JACKSON, W.A.; McCREERY, R.A. Influence of limestone and nitrogen on soil $\mathrm{pH}$ and Coastal bermudagrass yield. Agronomy Journal, v.59, n.1, p.450-453, 1967.

ALCÂNTARA, V.B.G.; PEDREIRA, J.V.S.; MATTOS, H.B.; ALMEIDA, J.E. Medidas "in vitro" de valores nutritivos de capins. I. Produção e digestibilidade "in vitro" de vinte e cinco capins durante o outono e inverno. Boletim de Indústria Animal, v. 38, n.2, p.155-176, 1981.

ALMEIDA, C.R.; MONTEIRO, F.A. Resposta de Cynodon dactylon cv. coastcross 1 a níveis de nitrogênio em solução nutritiva. In: CONGRESSO BRASILEIRO DE CIÊNCIA DO SOLO, 25. Viçosa, 1995. Resumos. Viçosa, UFV, 1955. v.2, p.743-744. 
ALVIM, M.J.; RESENDE, H.; BOTREL, M.A. Efeito da freqüência de cortes e do nível de nitrogênio sobre a produção e qualidade da matéria seca do "coast-cross". In: WORKSHOP SOBRE O POTENCIAL FORRAGEIRO DO GÊNERO CYNODON, Juiz de Fora, 1996. Anais. Juiz de Fora: EMBRAPA, CNPGL, 1996. p.45-55.

ANDRADE, J.B.; FERRARI JÚNIOR, E.; HENRIQUE, W. Efeito das adubações nitrogenada e potássica na produção e no valor nutritivo do feno de capimcolonião. Boletim de Indústria Animal, v.48, n.2, p. 93-99, 1991.

ANDRIGUETTO, J.M.; PERLY, L.; MINARDI, I.; GEMAEL, A.; FLEMMING, J.S.; SOUZA, G.A.; BONA FILHO, A. Nutrição animal. 4. ed. São Paulo: Nobel, 1988. 395p.

ASPIOLEA, J.L.; DÍAZ, B. Respuesta de la Bermuda cruzada a la fertilización potasica con dos fondos de $\mathrm{N}$ en suelo pardo grizáceo. Ciencia y Técnica en la Agricultura, Suelos y Agroquímica, v.4, n.2, p.47-64, 1981.

BELESKY, D.P.; PERRY, H.D.; WINDHAM, W.R.; MATHIAS, E.L.; FEDDERS, J.M. Productivity and quality of bermudagrass in a cool temperate enviroment. Agronomy Journal, v.83, n.5, p.810-813, 1991.

BELTRAN, B.R.; SANTA CRUZ, J.J.H. Nuevas posibilidades para la produccion forrajera del regadio: Henificacion natural del Coastcross-1 bermudagrass. Comunicaciones I.N.I.A. Ser. Produccion Vegetal, n. 66, p.5$48,1985$. 
BLASER, R.E. Symposium on forage utilization: effects of fertility levels and stage of maturity on forage nutritive value. Journal of Animal Science, v. 23, n. 1, p. 246-253, 1964.

BROWN, W.E.; SPIERS, J.M.; THURMAN, C.W. Performance of five warmseason perennial grasses grown in southern Mississippi. Agronomy Journal, v.68, n.4, p.821-823, 1976.

BUFARAH, G.; PEDREIRA. J.V.S.; MATTOS, H.B. Adaptação de plantas forrageiras no litoral sul do Estado de São Paulo. Boletim de Indústria Animal, v.39, n.2, p.81-92, 1982.

BURTON, G.W. Breeding bermuda grass for the southeastern United States. Journal of the American Society of Agronomy, v.39, n.7, p.551-569, 1947.

BURTON, G.W. Registration of Coastacross-1 bermudagrass. Crop Science, v.12, n.1, p.125, 1972.

BURTON, G.W.; DEVANE, E.H. Effect of rate and method of applying different sources of nitrogen upon the yield and chemical composition of bermudagrass, Cynodon dactylon (L) Pers., hay. Agronomy Journal, v.44, p.128-132, 1952.

BURTON, G.W.; MONSON, W.G. Harvest frequency and fertilizer effects on yield, quality, and persistence of eight bermudagrasses. Agronomy Journal, v.74, n.2, p. 371-374, 1982. 
BURTON, G.W.; MONSON, W.G. Registration of Tifton 68 bermudagrass. Crop Science, v.24, n.6, p.1211, 1984.

BURTON, G.W.; GATES, R.N.; HILL, G.M. Registration of Tifton 85 bermudagrass. Crop Science, v.33, p.644-645, 1993.

BURTON, G.W.; HART, R.H., LOWREY, R.S. Improving forage quality in bermudagrass by breeding. Crop Science, v.7, p.329-545, 1967.

BURTON, G.W.; JACKSON, J.E.; HART, R.H. Effects of cutting frequency and nitrogen on yield, in vitro digestibility, and protein, fiber, and carotene content of Coastal bermudagrass. Agronomy Journal, v. 55, n. 2, p.500-502, 1963.

CÁCERES, O.; SANTANA, H.; DELGADO, R. Influencia de la fertilizacion nitrogenada sobre el valor nutritivo y rendimiento de nutrimentos. Pastos y Forrages, v.12, n.2, p.189-195, 1989.

CAIELLI, E.L.; WERNER, J.C.; BONILHA NETTO, L.M. Valor nutritivo de fenos de nove leguminosas tropicais e do capim-gordura (Melinis minutiflora Pal. de Beauv.). Boletim de Indústria Animal, v.36, n. 2, p.229-245, 1979.

CARO-COSTAS, R.; ABRUÑA, F.; CHANDLER, J.V. Effect of three levels of fertilization on the productivity of stargrass pastures growing on a Steep Ultisol in the humid mountain region of Puerto Rico. The Journal of Agriculture of the University of Puerto Rico, v.60, n.2, p. 173-178, 1976. 
CASTRO, A.C.G.; SILVA, J.F.C.; LAFETA, M.A.Q. Estudo da composição química, digestinilidade in vitro da matéria seca e desempenho de novilhos nelorados tratados com diferentes volumosos, durante a estação seca. Revista da Sociedade Brasileira de Zootecnia, v. 21, n. 3, p. 447-455, 1992.

COMBELLAS, J.; GONZÁLEZ, E.; TRUJILLO, A. Rendimento y valor nutritivo de forrajes tropicales. 1. Bermuda cv. Coastal (Cynodon dactylon) (L) Pers. Agronomia Tropical, v.22, n.3, p. 231-238, 1972.

CORSI, M.; SILVA, R.T.L. Fatores que afetam a composição mineral de plantas forrageiras. In: SIMPÓSIO SOBRE NUTRIÇÃO DE BOVINOS, 3, 1985. Mineral para ruminantes, p.1-14.

COTO, G.; HERRERA, R.S.; CRUZ, R.; HERNANDEZ, Y.; PEREZ, M. Effect of season and $\mathrm{N}$ fertilization on the quality and solubility of protein of bermuda grass. Cuban Journal of Agricultural Science, v.24, n.1, p. 117$122,1990$.

CRIPPS, R.W.; YOUNG, J.L.; LEONARD, A.T. Effects os potassium and lime applied for Coastal bermudagrass production on sandy soil. Soil Science Society of America Journal, v. 53, n. 1, p.127-132, 1989.

CRUZ, M.C.P.; FERREIRA, M.E.; LUCHETTA, S. Efeito da calagem sobre a produção de matéria seca de três gramíneas forrageiras. Pesquisa Agropecuária Brasileira, v. 29, n. 8, p. 1303-1312, 1994. 
DAIUB, J.A.S. Efeito da maturidade sobre a produção, composição químicabromatológica e digestibilidade in vitro da matéria seca de Digitaria decumbens Stent. cv. Transvala. Piracicaba, 1994. 105p. Dissertação (Mestrado) - Escola Superior de Agricultura "Luiz de Queiroz", Universidade de São Paulo.

DAY, J.L.; PARKER, M.B. Fertilizer effects on crop removal of $\mathrm{P}$ and $\mathrm{K}$ in "Coastal" bermudagrass forage. Agronomy Journal, v.77, n.1, p.110-114, 1985.

DIAS FILHO, M.B.; CORSI, M.; CUSATO, S.; CAMARÃO, A.P. Digestibilidade in vitro da matéria orgânica e teor de proteína bruta em Panicum maximum Jacq. cv. Tobiatã sob estresse hídrico. Pesquisa Agropecuária Brasileira. v. 26, n. 10, p.1725-1729, 1991.

DUBLE, R.L.; LANCASTER, J.A.; HOLT, E.C. Forage characteristics limiting animal performance on warm-season perennial grasses. Agronomy Journal, v.63, n.5, p.795-798, 1971.

EICHHORN JUNIOR, M.M.; AMACHER, M.C. Potash for Coastal bermudagrass increases hay yields, saves stands. Better Crops with Plant Food, v. 72, n. 1, p.18-20, 1987/88.

EICHHORN JUNIOR, M.M.; HALLMARK, W.B. Nutrient levels in plant tissue indicate optimum potash rates for Coastal bermudagrass. Better Crops with Plant Food. v. 73, n. 2, p. 16-17, 1989. 
EICHHORN JUNIOR, M.M.; NELSON, B.D. Potash boosts nutritive value and yields of Coastal bermudagrass. Better Crops with Plant Food, v.72, n.3, p.10-11, 1988.

FAVORETTO, P.S.; MONTEIRO, F.A. Carências de macronutrientes em aveia cultivar Upf-7. In: REUNIÃO PAULISTA DE INICIAÇÃO CIENTÍFICA EM CIÊNCIAS AGRÁRIAS, 3. Taubaté, 1992. Anais. Taubaté: UNITAU, 1992. p.68.

FERRARI JÚNIOR, E.; RODRIGUES, L.R.A.; REIS, R.A.; COAN, O.; SCHAMMAS, E.A. Avaliação do capim coast cross para produção de feno em diferentes idades e níveis de adubação de reposição. Boletim de Indústria Animal, v. 50, n. 2, p. 137-145, 1993.

FORDE, B.J.; SLACK, C.R.; ROUGHAN, P.G.; HASLEMORE, R.M. Growth of tropical and temperate grasses at Palmerston North. II. Total nitrogen, soluble sugar, starch, and in vitro digestibility determinations. New Zealand Journal of Agricultural Research, v.19, n.4, p.489-498, 1976.

FRANÇA, A.F.S.; HAAG, H.P. Nutrição mineral de gramíneas tropicais. I. Carências nutricionais de capim Tobiatã (Panicum maximum Jacq.). Anais da Escola Superior de Agricultura "Luiz de Queirroz", v. 62, p. 83-95, 1985. 
FREITAS, L.M.M.; JORGE, J.P.N. Resposta de capim-swannee-bermuda a aplicação de nitrogênio, fósforo e enxofre em região de cerrado. Revista Brasileira de Ciência do Solo, v. 6, p.195-202, 1982.

GALLO, J.R.; HIROCE, R.; BATAGLIA, O.C.; FURLANI, P.R.; FURLANI, A.M.C.; MATTOS, H.B.; SARTINI, H.J.; FONSECA, M.P. Composição química inorgânica de forrageiras do Estado de São Paulo. Boletim de Indústria Animal, v.31, n.1, p.115-137, 1974.

GARCIA SOLDEVILLA, F; MEDEROS, M.L.; VASQUEZ, C.M.; RODRIGUEZ, I. Influencia de la carga sobre la calidad del material beleccionado en cuatro pastos tropicales. Pastos y Forrages, v.4, n.1, p. 1522,1981 .

GLÓRIA, N.A. Adubação potássica de pastagens. In: SIMPÓSIO SOBRE MANEJO DA PASTAGEM, 8. Piracicaba, 1986. Anais. Piracicaba: FEALQ, 1986. p. 225-230.

GOERING, N.K.; VAN SOEST, P.J. Forage fiber analysis: apparatus, reagents, procedures and some applications. Washington: USDA, 1970. 20 p. (USDA - Handbook, 379).

GOMIDE, J.A.; NOLLER, C.H.; MOTT, G.O.; CONRAD, J.H.; HILL, D.L. Mineral composition of six tropical grasses as influenced by plant age and nitrogen fertilization. Agronomy Journal, v. 61, p. 120-123, 1969. 
GOMIDE, J.A.; ZAGO, C.P.; CRUZ, M.E.; LEMPP, B.; SILVA, M.G.C.M.; CASTRO, C.G. Avaliação de alimentos volumosos: I. Fenos, silagens e restos culturais na alimentação de vacas em lactação. Revista da Sociedade Brasileira de Zootecnia, v. 16, n. 3, p. 284-298, 1987.

GONZALEZ, Y.; OILDA, T.,S. Niveles criticos de K en Guinea comúm SIH127, Buffel cv. Biloela y Bermuda cv. Coastcross-1. Pastos y Forrajes, v. 5, n. 1, p. 49-57, 1982.

GONZALEZ, S.B.; RAMOS, N.; SANCHEZ, M. The effect of nitrogen fertilization on the mineral composition of five Cynodon species. Cuban Journal of Agricultural Science, v.17, n.2, p. 213-221, 1983.

GUTIERREZ, O.; GEERKEN, C.M.; FUNES, F.; DIAZ, A. Contents and digestibility of phosphorus and dry matter in tropical pastures (Digitaria decumbens and Cynodon dactylon). Cuban Journal of Agricultural Science, v.14, n.2, p. 159-163, 1980.

HADDAD, C.M.; PLATZECK, C.O. Pastagens para equinos. In: SIMPÓSIO SOBRE MANEJO DE PASTAGENS, 8. Piracicaba, 1986. Anais. Piracicaba: FEALQ, 1986. p.361-374.

HANNA, W.W.; MONSON, W.G.; BURTON, G.W. Histological and in vitro digestion study of 1- and 4-week stems and leaves from high and low quality bermudagrass genotypes. Agronomy Journal, v.68, n.2, p.219-222, 1976. 
HARLAN, J.R. Cynodon species and their value for grazing and hay. Herbage Abstract, v.40, n.3, p.233-238, 1970.

HARLAN, J.R.; WET, J.M.J. de. Sources of variation in Cynodon dactylon (L). Pers. Crop Science, v.9, n.6, p.774-778, 1969.

HASS, F.J. Correlações entre as concentrações de nutrientes, alumínio e sódio nas folhas de forrageira "Coast cross n.1" (Cynodon spp.) e a análise física e química de um latossolo vermelho amarelo, Jaguariuna, SP. Piracicaba, 1986. 100p. Dissertação (Mestrado) - Escola Superior de Agricultura "Luiz de Queiroz", Universidade de São Paulo.

HERNÁNDEZ, M.; CÁRDENAS, M. Efecto del nivel y frecuencia de aplicacion del $\mathrm{K}$ en el pasto estrella cv. jamaicano (Cynodon nlemfuensis). Pastos y Forrages, v.10, p.61-66, 1987.

HERNÁNDEZ, M.; CÁRDENAS, M. Respuesta del pasto estrella jamaicano a niveles de NPK en un suelo ferralitico cuarcitico. Pastos y Forrages, v.13, p.273-277, 1990 .

HERRERA, R.S. Effect of the season and nitrogen fertilization on some nutritive value components of bermuda grass (Cynodon dactylon Coast Cross no. 1). Cuban Journal of Agricultural Science, v.13, n.1, p. 101-112, 1979a. 
HERRERA, R.S. Stem and leaf contribution to the chemical composition of Cynodon dactylon cv. Coast cross 1. Cuban Journal of Agricultural Science, v.13, n.3, p. 307-314, 1979 b.

HERRERA, R.S.; HERNANDEZ, Y. Efecto de la fertilizacion nitrogenada en la calidad de Cynodon dactylon cv. Coastcross-1. I. Rendimento de materia seca, proteina bruta y porcentaje de hojas. Pastos y Forrages, v.8, p.227237, 1985a.

HERRERA, R.S.; HERNANDEZ, Y. Efecto de la fertilizacion nitrogenada en la calidad de Cynodon dactylon cv. Coastcross-1. II. Componentes solubles. Pastos y Forrages, v.8, p.399-412, 1985 b.

HERRERA, R.S.; HERNANDEZ, Y. Efecto de la edad de rebrote en algunos indicadores de la calidad de la bermuda cruzada-1. I. Componentes solubles. Pastos y Forrages, v.10, p.160-168, 1987.

HERRERA, R.S.; RAMOS, N. Bermuda grass response to nitrogen fertilization and age of regrowth. 3. Hydrocarbon components. Cuban Journal of Agricultural Science, v.17, n.2, p. 203-212, 1983.

HERRERA, R.S.; RAMOS, N.; HERNANDEZ, Y. Bermuda grass response to nitrogen fertilization and age of regrowth. 4 . Digestibility and silica contents. Cuban Journal of Agricultural Science, v.19, n.2, p. 217-223, 1985. 
HILL, G.M.; GATES, R.N.; BURTON, G.W. Forage quality and grazing steer perfomance from Tifton 85 and Tifton 78 bermudagrass pastures. Journal of Animal Science, v.71, n. 12, p. 3219-3225, 1993.

HOLT, E.C.; CONRAD, B.E. Influence of harvest frequency and season on bermudagrass cultivar yield and forage quality. Agronomy Journal, v. 78, p. 433-436, 1986.

JORDAN, H.; ELIAS, A.; CABALLERO, A.; PEREZ, I.; VAZQUEZ, F. Relationship between protein and dry matter digestibility of coast cross bermuda No. 1 (Cynodon dactylon cv. coast cross 1) according to simulation of different leaf:stem proportions. Cuban Journal of Agricultural Science, v.15, n.2, p. 191-197, 1981.

KAPPEL, L.C.; MORGAN, E.B.; KILGORE, L.; INGRAHAM, R.H.; BABCOCK, D.K. Seasonal changes of mineral content of southern forages. Journal of Dairy Science, v. 68, n. 7, p.1823-1827, 1985.

LOPES, J.R.C.; MONKS, P.L. Produção de forragem de grama bermuda (Cynodon dactylon (L.), Pers.) cv. Coastcross 1. Resultados preliminares. In: REUNIÃO ANUAL DA SOCIEDADE BRASILEIRA DE ZOOTECNIA, 20, Pelotas, 1983. Anais. Pelotas:SBZ, 1983. p.364.

MALAVOLTA, E. Manual de química agrícola. São Paulo: Agronômica Ceres, 1981. 596p. 
MALAVOLTA, E.; LIEM, T.H.; PRIMAVESI, A.C.P.A. Exigências nutricionais das plantas forrageiras. In: SIMPÓSIO SOBRE CALAGEM E ADUBAÇÃO DE PASTAGENS, 1., Nova Odessa, 1985. Piracicaba: Associação Brasileira para Pesquisa da Potassa e do Fosfato, 1986. p.31-76.

MARASCHIN, G.E.; MOTT, G. Resposta de uma complexa mistura de pastagem tropical a diferentes sistemas de pastejo. Pesquisa Agropecuária Brasileira, v.24, n.2, p.221-227, 1989.

MATOCHA, J.E.; SMITH, L. Influence of potassium on Helminthosporium cynodontis and dry matter yields of "Coastal" bermudagrass. Agronomy Journal, v.72, n.4, p.587-592, 1983.

MESA, A.R.; MENDOZA, F.; AVILA, V. Rendimiento, composicion quimica y niveles criticos de potasio en cuatro gramineas tropicales. Pastos y Forrages, v.12, p.43-51, 1989.

MINSON, D.J.; McLEOD, M.N. Um rápido sistema in vitro para medir digestibilidade em espécies forrageiras. Zootecnia, v.14, n.2, p.109-116, 1976.

MONKS, P.L.; LOPES, J.R.C. Produção de forragem de grama bermuda (Cynodon dactylon (L.), Pers.) cv. Coastcross 1 . Resultados do $1^{0}$ ano. In: REUNIÃO ANUAL DA SOCIEDADE BRASILEIRA DE ZOOTECNIA, 20. Pelotas, 1983. Anais. Pelotas:SBZ, 1983. p.366. 
MONSON, W.G.; BURTON, G.W. Harvest frequency and fertilizer effects on yield, quality, and persistence of eight bermudagrasses. Agronomy Journal, v.74, p. 371-374, 1982.

MONTEIRO, F.A. Adubação para estabelecimento e manutenção de capimelefante. In: SIMPÓSIO SOBRE CAPIM-ELEFANTE, 1, Coronel Pacheco, 1990. Anais. Coronel Pacheco: EMBRAPA-CNPGL, 1990, p.35-58.

MONTEIRO, F.A.; LIMA, S.A.A.; WERNER, J.C.; MATTOS, H.B. Adubação potássica em leguminosas e em capim colonião (Panicum maximum Jacq.) adubado com niveis de nitrogênio ou consorciado com leguminosas. Boletim de Indústria Animal, v.37, n.1, p.127-148, 1980.

MONTEIRO, F.A.; MATTOS, W.T.; MARTIM, R.A. Partes das plantas e diagnose nutricional de fósforo em braquiária decumbens. In: CONGRESSO BRASILEIRO DE CIÊNCIA DO SOLO, 25. Viçosa, 1995. Resumos expandidos. Viçosa: Universidade Federal de Viçosa, 1995a. p.556-557.

MONTEIRO. F.A.; RAMOS, A.K.B.; CARVALHO, D.D.; ABREU, J.B.R.; DAIUB, J.A.S.; SILVA, J.E.P.; NATALE, W. Cultivo de Brachiaria brizantha Stapf. cv. Marandu em solução nutritiva com omissões de macronutrientes. Scientia Agricola, v.52, n.1, p.135-141, 1995b.

MOTT, G.O. Symposium on forage evaluation: IV. Animal variation and measurement of forage quality. Agronomy Journal, v.51, n.4, p. 223-226, 1959. 
MOURA, M.P.; WERNER, J.C.; MONTEIRO, F.A.; BOIN, C. Velocidade de fenação, relação lâmina-haste e teores de proteína nas lâminas e nas hastes de algumas leguminosas tropicais perenes e no capim-gordura. Boletim de Indústria Animal, v.32, n. 2, p.363-370, 1975.

NASCIMENTO JÚNIOR., D.; PINHEIRO, J.S. Valor nutritivo do capim-jaraguá em diferentes idades. Revista da Sociedade Brasileira de Zootecnia, v.4, n.1, p.101-113, 1975.

NELSON, L.R.; KEISLING, T.C.; ROUQUETE JÚNIOR, F.M. Potassium rates and sources for Coastal bermudagrass. Soil Science Society of América Journal, v.47, n.5, p.963-966, 1983.

OLUBAJO, F.O.; VAN SOEST, P.J.; OYENUGA, V.A. Comparison and digestibility of four tropical grasses grown in Nigeria. Journal of Animal Science, v.38, n.1, p.149-153, 1974.

PACHECO, O.; MENDOZA, L.; JUAN, R.; AVILA, Y.A. Influencia de la fertilización NPK sobre el rendimento y contenido mineral del pasto estrella jamaicano. Agrotecnia de Cuba, v.19, n.1, p.109-113, 1987.

PALHANO, A.L. Recrutamento de nutrientes e valor nutritivo Cynodon dactylon (L.) Pers. cv. Coastcross 1. Piracicaba, 1990. 122p. Dissertação (Mestrado) Escola Superior de Agricultura "Luiz de Queiroz", Universidade de São Paulo. 
PEDREIRA, C.G.S. Plant and animal responses on grazed pastures of "Florakirk" and "Tifton 85" bermudagrasses. 1995. 152p. Tese (Ph-D) University of Florida.

PEDREIRA, C.G.S. Avaliação de novas gramíneas do gênero Cynodon para a pecuária do sudeste dos Estados Unidos. In: WORKSHOP SOBRE O POTENCIAL FORRAGEIRO DO GÊNERO CYNODON, Juiz de Fora, 1996. Anais. Juiz de Fora: EMBRAPA, CNPGL, 1996. p.111-125.

PEDREIRA, J.V.S.; MATTOS, H.B. Crescimento estacional de vinte e cinco espécies ou variedades de capins. Boletim de Indústria Animal, v.38, n.2, p.117-143, 1981.

PINTO, J.C.; GOMIDE, J.A.; MAESTRI, M. Produção de matéria seca e relação folha/caule de gramíneas forrageiras tropicais. In: REUNIÃO ANUAL DA SOCIEDADE BRASILEIRA DE ZOOTECNIA, 29. Lavras, 1992. Anais. Lavras: SBZ, 1992, p.74.

REID, R.L.; JUNG, G.A.; KINSEY, C.M. Nutritive value of nitrogen-fertilized Ochardgrass pasture at different periods of the year. Agronomy Journal, v.59, n.6, p.519-525, 1967a.

REID, R.L.; ODHUBA, E.K.; JUNG, G.A. Evaluation of tall fescue pasture under different fertilization treatments. Agronomy Journal, v.59, p.265-271, $1967 b$. 
WHITEHEAD, D.C. Grassland nitrogen. Wallingford: Cab International, 1995. $397 p$.

WILSON, J.R.; DEINUM, B.; ENGELS, F.M. Temperature effects on anatomy and digestibility of leaf and stem of tropical and temperate forage species. Netherlands Journal of Agricultural Science, v.39, n.1, p.31-48, 1991.

WOEFEL, C.G.; POULTON, B.R. The nutritive value of Timothy hay as affected by nitrogen fertilization. Journal of Animal Science, v.19, n.3, p.695-699, 1960. 